\title{
THE CASE OF THE MYSTERIOUS ACCESSORY
}

\author{
R. BRuce TOWNSEND*
}

The American automobile has acquired another accessory. It comes on all models. This accessory, an impressive little item, is the certificate of title, which serves as the automobile's passport from dealer to owner to banker to thief, and more often than not, back to the dealer again. Often it embroils these characters in a mystery of deep legislation and dark case law. This mystery has found its way into the Uniform Commercial Code.

The writer believes that he has a solution to this mystery. The illustration of the proffered solution will require a broad review of the legal aspects of the motor vehicle title problem as it has been created by legislation and judicial law. Upon this predicate may be described the role the certificate will play under the new uniform act, with special attention being given to its use as an instrument for imparting notice of liens. After this will come the solution.

The slip of paper which serves as a certificate of title originated as a police device for tracking down stolen automobiles. With such a piece of paper a central motor vehicle agency is able to identify every automobile by engine serial number, keep informed of current ownership transfers, maintain permanent records, and provide the owner with an accessory which informs the public of his ownership rights. This certificate differs from the established negotiable instruments, the bill of lading, and the warehouse receipt in that it is no more negotiable than the automobile to which it is attached. It also differs from the sale receipt or the bill of sale because it has an official origin. In short it is something new in the commercial world; but the nature of its commercial value and its significance to the automobile has remained an unprobed mystery.

The codifiers saw the problem, wrestled with it, ${ }^{1}$ and finally discarded their efforts to give any degree of uniformity to this certificate of title. Rather the Code met the issue by a "meshing process," which for lack of a better name is used to describe a function that will increasingly be faced in the job of uniform codification. This "meshing process" is the means by which diverse patterns of legislation and case law are assimilated into a body of uniform private law. For example, the Code recognizes that constructive notice can be shown through the title certificate and public records established and maintained under the various title certificate laws. ${ }^{2}$

A.B. 1938, Coe College; J.D. 1940, State University of Iowa. Associate Professor of Law, Indiana University School of Law, Indianapolis Division.

${ }^{1}$ A Reporter's draft of a comprehensive chapter dealing with the certificate of title problem was presented in the May, 2949 draft of the Uniform Commercial Code. \$7-80r et seq.

For an excellent discussion of the conflicts problems under the title certificate laws, see Leary, Horse and Buggy Lien Law and Migratory Automobiles, 96 U. OF PA. L. REv. 455 (1948).

${ }^{2}$ U. C. C. $\$ 9-402$ (Scpt. 1950). 
In so doing, the Code has introduced nothing new, but instead has recognized and adopted the type of legislation which exists in a majority, but not all; af the states. According to the Code, security interests in motor vehicles are perfected only when the lien is noted upon the records and upon the title certificate. In addition, the Code does not clearly define the states which are encompassed by the provision, for it applies only to those states requiring the registration of "all liens" upon the certificate of title. Thus the Code shuts the door on the possibility that the title certificate itself may become a new document of commerce which in fact represents title rights and gives constructive notice of liens.

At the outset it is feasible to illustrate the practical utility of the certificate of title as a commercial device. Suppose that $M$, who allegedly owns a Chevrolet, applies to $F$ bank for a loan upon the security of this car late one Saturday morning. During the course of the customary interview between $M$ and $F$ 's loan officer, $M$ produces an official certificate of title showing no encumbrances. The officer, after an examination of the Chevrolet to determine its identity as expressed in the certificate, is able to make the loan in a very few minutes. The bank can take possession of the certificate and feel relatively sure that the title is good. On the other hand, consider this business routine in states without title certificate laws. The officer of $F$, if he is as cautious as he ought to be, will check the chattel mortgage and conditional sale records in the county court house prior to making the loan. This may be impossible late in the morning because the business week end is at hand. The transaction, therefore, will be delayed, and if $M$ is in desperate need he will be forced to resort to a more expensive source of credit. Or the bank, if it makes the loan as a pure credit risk until the lien can be filed, may subject itself to the wrath of the bank examiners, to the possibility that a lien has already been entered upon the records, and to the contingency that $M$ will take his Chevrolet to a used car dealer in the afternoon. Without examining the lien records and filing the lien $F$ is taking security of questionable value, and even after such examination and filing there is the additional risk that $M$ was not the actual owner of the car. This is but one of the many situations which commend the title certificate to the commercial world as an indispensable accessory.

\section{StatuToRy Provisions}

States with registration laws. At the present time fourteen states, including Alabama, Connecticut, Georgia, Iowa, Kentucky, Maine, Massachusetts, Minnesota, Mississippi, New Hampshire, New York, Rhode Island, South Carolina, and Vermont have adopted legislation requiring registration, but making no provision for a separate certificate of title. ${ }^{3}$ As a consequence, the registration certificate or receipt serves a purpose similar to that of the certificate of title, although the legislation in these states manifests no clear intent that the mechanics of registration or the registra-

\footnotetext{
${ }^{3}$ See App. x, supra.
} 
tion instrument should impart notice of ownership.* Basically, these laws employ registration as a device for collecting revenue by outlawing the operation of unregistered vehicles. 5 Additional features, however, tend to make the registration machinery and the registration certificate a possible source of title information.

Most of these states require the "owner" to register the vehicle upon acquisition, and the term is usually defined to include mortgagors and conditional buyers in, or

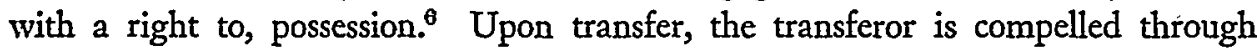
criminal sanctions to notify the vehicle department of the transfer, either upon the registration certificate, or in a manner otherwise prescribed. ${ }^{\top}$ Endorsement and delivery of the instrument to the transferee is made mandatory in only two states, Georgia and Kentucky, ${ }^{8}$ but the transferee and transferor are required to join in an assignment of the certificate of registration in Iowa and Minnesota. ${ }^{9}$ In Georgia and South Carolina, liens must be shown upon applications for registration, but no further provisions for noting the lien upon the registration certificate, pointing out the intended connection with other filing statutes, or describing the general effect of such procedure, are to be found. ${ }^{10}$ Therefore, it will be observed that the registration laws do not, in terms, comprehend a method whereby constructive notice of liens and encumbrances may be imparted through registration or the registration certificate. Most of the states, however, provide for recording and indexing initial registrations and transfers, thus indicating that the machinery for centralized filing or recording is present in every state. ${ }^{11}$ In seven of these jurisdictions the registration certificate must be carried or exhibited in the vehicle, consequently destroying the usefulness of the instrument as a document of commerce. ${ }^{12}$

States with certificate of title laws-in general. Certificate of title legislation has steadily gained in popularity so that at the present time 35 jurisdictions ${ }^{13}$ have adopted legislation requiring ownership interests in motor vehicles to be cleared through an official document known as the certificate of title. Like the registration

\footnotetext{
- None of the statutes expressly provide that the registration receipt or the registration records should constitute constructive notice to creditors, purchasers, or lienholders. Mississippi requires the transferor to give a bill of sale, which may be recorded in county records, but the statute says nothing of the rights of creditors or purchasers.

${ }^{\Xi}$ See e.g., Bolton-Swanby Co. v. Owens, 201 Minn. I62, 275 N. W. 855, 857 (1937); 22 MrNs. L. REv: 720 (1938).

- All of the states except Massachusetts have general provisions accomplishing this result. See statutes cited Appendix I, col. I. In Massachusetts a motor vehicle may be registered in the name of the conditional seller. Temple v. Middlesex \& B. St. Ry., 24I Mass. I24, I34 N. E. 64I (I922).

T Alabama, Connecticut, Massachusetts, Minnesota, New Hampshire Rhode Island, South Carolina, and Vermont have such provisions. See App. I, col. 2. In some states, a non-resident applicant for registration must furnish the certificate of title held under the laws of another state. E.g., Ky. REv. STAт. \$186.020 (c-d) (1948); MinN. Stat. \$I68.13 (1949).

${ }^{8}$ See App. I, col. 3 .

See App. I, col. 3.

${ }^{10}$ GA. COde AnN. $\$ 68-207$ (I937); S. C. Code ANN. $\$ 5894$ (I7) (Supp. I949).

${ }^{11}$ In Direct Mail Service v. Registrar of Motor Vehicles, 296 Mass. 353, 5 N. E.2d 545 (I937), the Registrar of Motor Vehicles was compelled by mandamus to permit inspection and the making of copies of the registration records.

${ }^{2}$ But cf. Commercial Credit Corp. v. Dassenko, 43 N. W.2d 299 (N. D. I950) (custom and usage of dealers to use certificate in obtaining loans).

${ }^{18}$ See Apps. 2-3.
} 
statutes in the other states, title certificate laws require owners of motor vehicles to comply with annual registration laws, but to facilitate the tracing of title, acquisition of a separate certificate of title is made mandatory. Consequently permanent title records, separate and apart from the registration machinery, as a matter of administrative routine facilitate the collection of permanent title data on each motor vehicle.

The structure of these laws roughly adheres to a uniform pattern. However, it is convenient to classify the statutes upon the basis of the comprehensiveness with which the legislatures have undertaken to vest the certificate of title with conclusiveness of all ownership interests. In nine states, ${ }^{14}$ the laws reflect a rather cursory effort to include lien or security interests within the group of ownership interests which may be registered upon the title certificate. For the purposes of this discussion these jurisdictions are separately classified as states with "incomplete" certificate of title laws. The other 26 states, ${ }^{15}$ either by specific inclusion or through the comprehensive character of the legislation, in most cases have manifested a calculated intent to require that lien interests be perfected through the title certificate machinery. These will be referred to as states with "comprehensive" certificate of title laws.

States with "incomplete" certificate of title laws. The statutes of Illinois, Indiana, Maryland, North Carolina, North Dakota, Oklahoma, South Dakota, West Virginia, and Wisconsin ${ }^{16}$ are modeled after the now obsolete Uniform Motor Vehicle Anti-Theft Act, which had as its purpose the prevention of theft by regulating transfers of this kind of property. ${ }^{17}$ "Owners," who are defined to exclude lienholders out of possession, ${ }^{18}$ are required to obtain a certificate of title and assign the certificate upon transfer to other "owners" who in turn must return the certificate to a central motor vehicle department. A record is thus maintained upon each motor vehicle under the engine serial number and usually the name of the owner, ${ }^{19}$ and this record, in turn, is noted upon the new certificate of title. In all of these states, failure to assign the certificate is penalized by criminal sanctions, but none of the laws expressly impose civil sanctions by invalidating transfers which do not comply. ${ }^{20}$ Since each successive owner is required to obtain a new certificate of title, the instrument does not circulate as a "negotiable" document, except as to dealers who are permitted to re-assign the certificate acquired upon the purchase of used automobiles. ${ }^{21}$ In none of these states are dealers required to obtain a certificate of title for new vehicles, but in Illinois, Indiana, Maryland, and North Carolina they

${ }^{14}$ See App. 2. $\quad{ }^{15}$ Seq App. 3. ${ }^{10}$ See App. 2.

${ }^{17}$ Cf. Uniforas Motor Vehtele ANTT-TheFt Act $\$ 6(\mathrm{~b})$, II U. L. A. 147 (1942). This act was declared obsolete by the Commissioners in 1943. Id. 10 (Supp. 1949).

${ }^{18}$ ILL. ANN. STAT. c. $95 \frac{112}{2}, 874$ (c) (r950); IND. STAT. ANN. $\$ 47-2402$ (o) (Burns Supp. 1949); MD. Ann. Code Gen. Laws art. 661/2, \$2 (3I) (Supp. I947); N. C. Gen. Stat. ANn. \$20-38(t) (Supp. I949); N. D. Rev. Stat. \$39.orox(22) (1943); OKLA. StaT. ANN. tit. 47, \$23.I (Supp. 1949); S. D. Laws c. 184 , p. 222 (194I); W. VA. CODE ANN. $\$ 1424$ (1949) ("owner" defined to include person holding "title"); WIs. STAт. \$85.10(16) (1947).

${ }^{19}$ See App. 2, col. 7 . ${ }^{20}$ Sce App. 2, col. 1.

${ }^{21}$ Indiana is the only state which (apparently) does not permit the dealer to re-assign the certificate of title without obtaining a new one. See App. 2, col. 5 . 
must obtain a manufacturer's certificate of origin which must pass upon transfers. ${ }^{22}$ The exceptions in favor of the dealer no doubt represent a legislative effort to facilitate trade in new and used motor vehicles. ${ }^{23}$ Most states provide specially for transfers effected by legal sales, repossession, or other involuntary proceedings. ${ }^{24}$

All of the legislation in these states permits liens existing at the time of transfer to be shown upon the certificate of title when issued by the state motor vehicle agency. But the statutes literally do not provide a method for perfecting liens thereon in absence of a transfer from one "owner" to another. ${ }^{25}$ None of the laws specify that the lien instrument must be filed or recorded, define the rights of purchasers and creditors, indicate the time the lien is to take effect., reconcile the effect of such laws on local recording statutes, or provide that notation of the lien upon the document shall constitute constructive notice. However, a legislative intent that the certificate of title should constitute a source of lien information is indicated in Illinois, Indiana, North Carolina, and North Dakota where the lienholder is permitted to hold possession of the certificate of title, ${ }^{26}$ and is compelled to effectuate a release upon the instrument. $^{27}$ In Wisconsin, the certificate must be retained by the person in possession of the vehicle. ${ }^{28}$

States with "comprehensive" certificate of title laws. A legislative scheme to establish the entire record of property transactions concerning motor vehicles is indicated, though in various degrees of conclusiveness, by the title certificate laws in 26 states, including Arizona, Arkansas, California, Colorado, Delaware, District of Columbia, Florida, Idaho, Kansas, Louisiana, Michigan, Missouri, Montana, Nebraska, Nevada, New Jersey, New Mexico, Ohio, Oregon, Pennsylvania, Tennessee, Texas, Utah, Virginia, Washington, and Wyoming. ${ }^{29}$ Like the statutes of the other certificate of title states, these statutes require "owners" 30 to obtain a certificate of title as a condition precedent to registration or operation upon the highways, and to assign it upon transfer to other "owners" who must apply for and receive a certificate of title. Some of the statutes invalidate transfers which do not comply by imposing

22 See App. 2, col. 5.

${ }^{23}$ It will be observed that in those states which do not require the dealer in new motor vehicles either to have a manufacturer's certificate or obtain a certificate of title, the certificate cannot constitute a valuable source of constructive notice to third persons.

${ }^{26}$ See App. 2, col. 9. ${ }^{25}$ See App. 2, col. 2

${ }^{27}$ See App. 2, col. 6. (Maryland also is included in this group.)

${ }^{28}$ See App. 2, col. 4.

${ }^{30}$ In most states "owner" is defined to mean a mortgagor or conditional buyer with a right of possession. ARIz. Code ANn. \$66-40I (Supp. I949); ARK. Dig. Stat. \$75-1 I I(b) (Supp. I949); CaL. VEhicle Code $\$ \$ 66-68$ (1948); Colo. StAt. ANn. c. 16, \$76(q) (I935); Del. Rev. Code \$5539(q) (I935); D. C. Code \$40-IOI (c) (1940); Fla. Stat. ANn. \$3I7.0I (14) (1949); Idaho Code ANN. \$49-40I (e) (Supp. I949); Kan. Gen. Stat. ANn. \$8-126(n) (Supp. 1947); LA. Rev. Stat. \$47:45I(26) (r950); Mich. Acts 1949, c. 300, $\$ 257.37$; Mo. Laws 1945, p. I I96, \$8367; Monr. Rev. Code ANn. $\$ 53^{-133(f)}$ (1947); Nev. Comp. Laws $\$ 4435$ (q) (Supp. I94I); N. M. Stat. ANn. \$68-roi (e) (I94I); Ore. CoMp. LAws \$§II5-IoI (25-26) (Supp. 1943); PA. Stat. ANn. tit. 75, \$2 (Supp. 1949); TENn. Code ANN. \$5538.10 (Williams Supp. 1949); Tex. Stat., Penat Code art. 1436-1, \$4 (1948); Utah Laws I935, c. 46, \$57-3a-I (u); Va. Code ANn. \$46-I(15) (1950); Wash. Rev. Stat. ANn. \$\$6312-I(e), (z) (Supp. 1943); Wro. Conp. Stat. ANn. $\$ \$ 60-10$ I (10), 60-20I (e) (1945); cf. Neb. Rev. Stat. $\$ 60-501$ (8) (Supp. 1949) ("safety responsibility" law); N. J. STAT. ANN. \$39:10-2 (Supp. 1950) ("buyer," "purchaser," and "contract" defined to accomplish same result). Ohio has no definition provision directly applicable. 
civil sanctions. Unfortunately, these laws do not describe the effect of non-compliance with respect to the rights of third persons, but instead either declare the transfer "void," or in other language prohibit the courts from giving effect to the transaction. In all, twelve states have such provisions, including California, Colorado, Florida, Idaho, Kansas, Missouri, Montana, Nebraska, Ohio, Pennsylvania, Texas, and Utah. ${ }^{31}$ Most of the remaining jurisdictions merely impose penal sanctions upon the parties where the certificate of title is not properly assigned and entered upon the records of the vehicle department. ${ }^{32}$ Upon transfer of used motor vehicles, most of the laws permit dealers to re-assign the certificate of title without applying for and obtaining a certificate in the dealer's name. ${ }^{33}$ Usefulness of the certificate of title in financing dealers upon the security of new motor vehicles is doubtful in a majority of the states where manufacturers are not required to furnish a manufacturer's certificate, or the dealer is not otherwise required to obtain or furnish a certificate of title to purchasers of new automobiles. ${ }^{34}$ Only in Arizona, Nebraska, New Jersey, Ohio, and Texas are dealers required to acquire, and transfer, a certificate from the manufacturer. As in the case of the other title laws, most statutes purport to govern procedure for involuntary transfers. ${ }^{35}$

Most of the states with comprehensive legislation have adopted elaborate provisions for noting liens upon the certificate of title and the records of the central department charged with administration of the law. ${ }^{36}$ With the exception of New Jersey, a means is clearly provided for perfecting liens upon the certificate either at the time of transfer or thereafter as a separate transaction. ${ }^{37}$ The lien instrument must be either filed or recorded in all these jurisdictions other than California, Florida, Kansas, Michigan, New Jersey, Oregon, Pennsylvania, Tennessee, Texas, Virginia, and Washington, where the information is stated upon the appropriate application. $^{38}$ In some states, including Colorado, ${ }^{30} \mathrm{Nebraska}^{40}{ }^{40} \mathrm{Ohio}^{41}$ and Wyoming, ${ }^{42}$ the procedure is that liens are noted upon the certificate by local agents and transmitted by them to the central department. In Missouri liens must be recorded locally, and, except upon transfer, there is no special provision for centralized recording of such liens. ${ }^{43}$

\footnotetext{
${ }^{31}$ See App. 3, col. 1 .

${ }^{32}$ See App. 3, col. 1.

${ }^{33} \mathrm{New}$ Jersey and Ohio require the dealer to acquire a new title. The District of Columbia has no express provision applying to dealers. See App. 3, col. 9 .

s4 Upon the sale of new vehicles most states require the dealer to give a bill of sale or join in an application for the certificate with the transferee. Many states require the dealer to notify the department of transfers, and in a few states the department must be notified of acquisitions. In the District of Columbia and Nevada, the law is not clear as to whether a dealer is required to obtain a certificate of title for new vehicles. See App. 3, col. 9. In Nevada a certificate of title is required as a condition to registration. Nev. Comp. Laws $\$ 4435.09$ (Supp. 1949). Registration is not required by dealers upon stock in trade. Id. \$4435.I5 (Supp. I94I). Consequently, it appears that the dealer need not acquire a certificate of title to new vehicles. In the District of Columbia a certificate is required by regulations. Fogle v. General Credit, Inc., I22 F.2d 45, n. 6 (D. C. Cir. r94I).

${ }^{35}$ See App. 3, col. I4.

${ }^{37}$ See App. 3, col. 2.

${ }^{30}$ Colo. Stat. AnN. c. 16, $\$ 13$ (19-21) (Supp. 1949).

${ }^{\circ 0}$ NeB. REv. STAT. \$60-Iro (1943)

See App. 3.

${ }^{38}$ See App. 3, col. 3 .

12 Wyo. Comp. Stat. ANn. $\$ \$ 60-206,60-208(f)$ (Supp. 1949).

${ }^{43}$ Mo. Laws r941, p. 328 , $\$ 3488$.
} 
That the certificate of title laws were intended to supersede local filing provisions is clearly expressed in all the states, other than Kansas, Michigan, New Jersey, New Mexico, Oregon, Pennsylvania, Washington, and Wyoming, where specific language to that effect was not found. ${ }^{44}$ Louisiana and Missouri are the only jurisdictions, however, which affirmatively require recording in accordance with other statutes. ${ }^{45}$ Language of the laws usually purports to include all "liens and encumbrances," although mortgages and conditional sales are customarily named. ${ }^{46}$ Trust receipts are specifically encompassed by the acts of Florida, Nebraska, New Jersey, Ohio, Tennessee, and Texas but excluded by the California and Missouri statutes. ${ }^{47}$ Compliance with the certificate of title legislation is not required of persons claiming by pledge or possessory lien in Arizona, Arkansas, Colorado, District of Columbia, Pennsylvania, Tennessee, and $\mathrm{Utah}^{48}$ and liens upon accessories are governed by the statutes in Michigan and Montana. ${ }^{40}$

Lack of uniformity distinguishes these laws with respect to constructive notice against third persons. Most of the enactments with specific provisions upon the subject fix the effective date of liens at the time of application, filing, or when the lien is noted upon the certificate by the proper officer. ${ }^{50}$ None of the statutes expressly state that possession of the certificate, alone and without formal compliance, is sufficient to constitute constructive notice. ${ }^{51}$ However, the importance of the document itself in manifesting the rights of lien claimants is recognized by provisions which give the lienholder a right to retain possession of the certificate, ${ }^{52}$ and upon discharge require its return to the lien-debtor. ${ }^{53}$ The title certificate laws present an unwholesome illustration of poor legislative draftsmanship in defining the specific rights of third persons where the lien is not properly perfected. ${ }^{54}$ Six states, Kansas, Michigan, New Jersey, Oregon, Washington, and Wyoming, altogether fail to mention the rights of third parties. Predominantly, the statutes protect "creditors, subsequent purchasers and lienholders," where the lien is not properly registered through the certificate of title. A summary of the general confusion, at best, deserves footnote space..$^{55}$ However, this general deficiency should furnish no serious obstacle in

"See App. 3, col. 6.

${ }^{45}$ See App. 3, col. 6 .

${ }^{10}$ See App. 3, col. 7.

${ }^{4}$ See App. 3, col. 7. The Virginia Traders' Act is expressly superseded by the certificate of title law. VA. CODE ANN. \$46-7I (I950). In those states where the depler is not required to obtain a certificate of title or manufacturer's certificate for a new vehicle, it is doubtful that floor plan financing can be accomplished through this instrument. E.g., ARK. DIG. STAT. $\$ \$ 75-160(a), 75-\times 32$ (I) (Supp. 1949) (lien provisions apply only to vehicles required to be registered); Kan. GEn. Stat. ANN. \$8-135(2) (Supp. 1947) (where certificate assigned to dealer, it is "deemed dormant" until re-transfer by him); VA. CODE ANN. \$46-106 (1950) (certificate of title not required of dealer upon new vehicles). In Louisiana, floor plan loans upon new vehicles are perfected by filing with Collector of Revenue, and without obtaining a certificate of title. La. Acts 1950, No. $342, \S_{13}(b)$.

${ }^{48}$ See App. 3, col. 7. ${ }^{4}$ See App. 3, col. 7. ${ }^{60}$ See App. 3, col. 4.

"I But of. D. C. CoDe $\$ 40-703$ (I940). $\quad$ "2 See App. 3, col. 8.

${ }^{63}$ See App. 3, col. Io. Eleven of the twenty-six states authorize assignments of the lienholder's interest to be registered upon the certificate of title. See App. 3, col. II.

ts See App. 3, col. 5 .

${ }^{65}$ Creditors: Most of the statutes provide generally that registration upon the certificate of title is constructive notice to "creditors." Arizona, California, Montana, Nevada, Pennsylvania, Tennessee, Texas, and Virginia. Others apply to creditors with or without process. Delaware, Florida, Nebraska, and Ohio. Two statutes apply to creditors without notice. Colorado and Idaho. Others are limited to lien 
statutory construction, because the general filing or recording laws stand in pari materia. ${ }^{56}$

\section{II}

\section{Registration Statutes as Imparting Constructive Notice of Liens}

As pointed out, most of the registration statutes do not provide the necessary mechanics for showing of liens through the registration certificate. ${ }^{57}$ None provide that either the registration records $s^{58}$ or the registration certificate shall constitute constructive notice of liens against creditors, subsequent purchasers, or lienholders. In many of the states, transferees are not required to obtain an endorsement of the certificate. Consequently, where the interests of lienholders appear upon the registration receipt, purchasers, lienholders, and creditors should comply with and receive the protection accorded by the general recording or filing laws, ${ }^{50}$ except to the extent that notice of the lienholder's interest shown upon the certificate is affirmatively called to the attention of third parties. ${ }^{60}$ The precise effect of the statutes in Georgia and South Carolina, which anticipate that liens may be shown upon the registration receipt, ${ }^{61}$ must remain inconclusive until the matter is settled by case law. It is extremely questionable, however, that these statutes, incomplete as they are, were intended to supersede the general recording statutes. Upon estoppel principles, however, it is reasonable to suppose that liens registered upon the certificate in these states without local filing, may be effective against third persons who actually see the lien upon the certificate before purchasing or extending credit upon the lien-debtor's apparent ownership.

creditors. Arkansas and New Mexico. And still another to lien creditors without notice. Utah.

purchasers: The bulk of the statutes are directed against "subsequent purchasers or lienholders." Arizona, California, Florida, Montana, Nebraska, Nevada, Ohio, Pennsylvania, Tennessee, 'Texas, and Virginia. Two statutes apply to such persons without notice. Idaho and Utah. And others include purchasers for "value." Colorado and New Mexico. In Arkansas the statute protects purchascrs "with or without notice." "Good faith" lienholders are protected by the New Mexico statute.

${ }^{\mathrm{E}}$ In Louisiana and Missouri the effect upon third persons of failure to comply with the title law is determined by the general recording statutes. La. Acts 1950, No. 342, \$13; Mo. Lavs 1941, p. 328, \$3488.

"See App. I.

${ }^{28}$ In some states the statutes specifically require the registration records to show the name of the owner and serial number of the vehicle. Iowa CODE $\$ 321.31$ (1950) (numerical and motor numbcr filc); ME. R'ev. Stat. c. 19, \$13 (1944) (under serial number and name of owner); MinN. Stat. \$168.33(3) (1949) (registered under name of owner, make, and serial number); N. Y. Ventcle \& Traffic Law $\$ 1 I(2)$ (I94I) (registered under name of owner and engine number). However, registration records are usually maintained upon a yearly basis only, and therefore provide a poor substitute for imparting constructive notice of the whole chain of title transfers. E.g., Kr. Rev. STar. \$186.240(2) (1948) ("numerical record" of registration numbers, only).

${ }^{50}$ Kurtz v. Adrian, 46 S. D. 125, I91 N. W. I 88 (1922) (mortgagee-seller who failed to record mortgage but kept registration in his own name defeated by subsequent bona fide purchaser from mortgagor); $c$. Clanton v. Thigpen, 226 S. W.2d 850 (Tex. Civ. App. 1950); Union Bank \& Trust Co. v. Willey, 237 lowa 1250, 24 N. W.2d 796 (r946); Cerex Co. v. Peterson, 203 Iowa 355,212 N. W. 890 (1927) (bill of sale given by $M$ to $E$ and recorded-held valid against creditors although no transfer of registration).

${ }^{80}$ Cf. Nelson v. Fisch, 39 N. W.2d 594 (Iowa 1949) (where certificate of title obtaincd in Nebraska was attached to bad check, and Iowa buyer purchased with notice that seller did not have title certificatc); see Rice Strcet Motors v. Smith, I67 Pa. Super. 159, 74 A.2d 535, 537 (1950) (court held that Minnesota registration certificate was indicium of owncrship, and said that New York receipt was not).

${ }^{\circ 1}$ See App. $x$, col. 4 . 
To lenders and purchasers of motor vehicles the principal value of the registration receipt will be found in its limited usefulness for checking title. ${ }^{62}$ In those states where the registration receipt must be assigned upon the transfer of "ownership" 03 third persons may be justified in relying upon the appearance of "ownership" created where both possession and a clear registration certificate are in the hands of one other than the real owner. ${ }^{64}$ Here the elements of estoppel combine to give the registration certificate an appearance of reliability, except, of course, as to security interests $^{65}$ which are excluded from the statutes requiring transfer of registration, and which are governed by the notice provisions of the recording acts. On the other hand, registration in the name of one other than the transferor may be sufficient to require further title investigation by a transferee who must qualify as a good faith purchaser. $^{66}$

The uncertainty of the extent to which estoppel will shield third persons in such cases is illustrated by two recent decisions arising out of the fraudulent conduct of a

os Cf. Kirk v. Madsen, 36 N. W.2d 757 (Iowa 1949). ${ }^{83}$ App. r, col. 3.

ot Possession plus the certificate of registration alone has been held sufficient to create an estoppel. Bailey v. Hoover, 233 Ky. 68I, 26 S. W.2d 522 (1930); see Moore v. Wilson, 230 Ky. 49, I8 S. W.2d 873, 874-5 (x929). Possession plus the certificate of title in a dealer may create an estoppel. Cf. Armstrong v. Boomansour, 223 App. Div. 5 I I, 228 N. Y. Supp. 722 (4th Dep't I928), aff'd mem., 252 N. Y. 590, I70 N. E. 155 (1929); Ross v. Leuci, 194 Misc. 345, 85 N. Y. S.2d 497 (N. X. City Ct. I949). A good faith purchaser from a seller in possession and with registration in his name has been protected against the claims of the buyer. Davis v. Grossman, 201 Minn. 156, 275 N. W. 858 (1937); Armstrong v. Boomansour, supra; cf. Moore v. Wilson, supra. A purchaser from one who has obtained title by fraud will find reliance upon the certificate of registration to be persuasive evidence of good faith. Cf. White v. Pike, $36 \mathrm{~N}$. W.2d 76I (Iowa 1949) (Iowa buyer taking assigned Nebraska certificate of title from one who had obtained vebicle by bad check prevailed over owner); Blount v. Bainbridge, 79 Ga. App. 99, 53 S. E.2d I22 (1949). The courts have shown disinclination to protect the purchaser upon the strength of a forged registration. Cadwallader v. Clifton R. Shaw, Inc., I27 Me. I72, I42 Atl. 580 (rg28) (bailee obtained registration in his name without authority from bailor); Royle v. Worcester Buick Co., 243 Mass. 143, 137 N. E. 531 (1922) (agent authorized to receive offers forged principal's name on registration certificate); cf. American Surety Co. of N. Y. v. Boden, 243 Ky. 805, 50 S. W.2d ro (x932) (owner gave agent possession with signed, blank bill of sale to be notarized when agent sold vehicle, but agent caused signature to be notarized-held that purchaser from agent could recover damages from notary). In Moberg v. Commercial Credit Corp., 42 N. W.2d 54 (Minn. 1950), the court refused to estop the owner against a bank which loaned upon the strength of a certificate assigned in blank to a dealer, partly upon the ground that this method of assignment was not authorized by the registration statute requiring both parties to join in a transfer. Creditors cannot claim an estoppel upon the ground that one in possession holds a certificate of registration unless credit is furnished upon the strength of the apparent ownership. Bolton-Swanby Co. v. Owens, 20r Minn. 162, 275 N. W. 855 (r937); Bosen v. Larrabee, 9r N. H. 492, 23 A.2d 33 I (r94I) (sheriff had notice of owner's claim before creditor obtained lien); cf. Cerex Co. v. Peterson, 203 Iowa 355,212 N. W. 890 (I927).

${ }^{85}$ This point is made beautifully by the case of Associates Discount Corporation v. Davis Motor Sales, 275 App. Div. 745,87 N. Y. S. 2d 757 (4th Dep't r949). There a dealer sold an automobile to $H$, who signed a conditional sale contract. A bill of sale, however, was given by the dealer to $W$, who in turn sold to a dealer upon a clear registration certificate. The assigneee of the dealer's contract prevailed over $W$ 's purchaser on the ground that the conditional sale records constituted the exclusive source of lien information. Quaere: Are the registration records to be construed with the chattel mortgage records to determine the chain of "ownership"? Cf. Personal Finance Co. of Hammond v. Flecknoe, 216 Ind. 330, 340,24 N. E.2d 694,698 (1940) (court indicated that registration certificate provided necessary information for discovering name and address of owner, which in turn would lead to proper lien records).

${ }^{\circ 0} \mathrm{Cf}$. Personal Finance Co. v. Flecknoe, 216 Ind. 330, 340, 24 N. E.2d 694, 698 (1940); Nelson v. Fisch, 39 N. W.2d 594 (Iowa 1949). But cf. Blount v. Bainbridge, 79 Ga. App. 99, 53 S. E.2d I22 (1949) (registration disregarded in finding estoppel against one who sold automobile in exchange for bad check). 
Minnesota used car dealer doing business near the Minnesota-North Dakota border. In each of these controversies an owner turned over his automobile to the dealer with the certificate of registration signed in blank, but upon the understanding that the dealer would be paid a commission if the vehicle were sold. The dealer, however, took the registration certificates to his bank and received a loan upon the security of the vehicles. In Commercial Credit Corporation v. Dassenko, ${ }^{67}$ the North Dakota Supreme Court allowed the bank to prevail over the owner, chiefly upon the ground that reliance was justifiably founded upon the certificate of registration. The Minnesota case of Moberg v. Commercial Credit Corporation ${ }^{68}$ held to the contrary, recognizing with reluctance the possibility of an estoppel, but refusing to find one on the ground that the evidence showed that the bank did not see the registration certificate until after the loan had been made. Since reliance constitutes an essential element of estoppel, the decisions can be reconciled. However, the Moberg decision clearly establishes the fact that the registration laws do not impart constructive notice of title interests.

Under the Uniform Commercial Code. Clearly, the Commercial Code will not modify the present statutes in the fourteen states with registration laws. In recognizing that security interests in motor vehicles may be perfected through a title instrument, the Code in terms is restricted to those states with "certificates of title" and allowing "all liens" to be registered under such laws. ${ }^{69}$ The registration statutes meet neither of these requirements. Only by a stretch of the imagination would the statutes of Georgia and South Carolina come within its language. In common acceptation the "registration" laws of these states do not provide for a separate title instrument usually required in the "title certificate" states. Nor do these statutes furnish the necessary machinery for noting "all liens" upon the certificate, in view of the fact that the statutes provide only for the registration of liens existing at the time ownership is transferred.

Changes effectuated by the Code with respect to the operation of existing registration laws will, if at all, be indirect. By imposing "an obligation of good faith" in the performance of contracts encompassed by the law, it is reasonable to suppose that the Code will expand the general principles of estoppel in relation to the registration certificate. ${ }^{71}$ Comment of the Editors recognizes that the acquisition of a "certificate of title," in those states with laws which "aim" at establishing an exclusive means of title evidence, becomes a part of what is statutorily required to satisfy "the course of trade" in so far as good faith dealing is imposed upon those dealing professionally with such commodity. ${ }^{22}$ Whether this provision will be applied to the registration

\footnotetext{
${ }^{07} 43$ N. W.2d 299 (N. D. I950).

${ }^{69}$ U. C. C. $\$ 9-402$ (Sept. I950).

${ }^{\text {o8 }} 42$ N. W.2d 54 (Minn. 1950).

to "Every contract within this Act imposes an obligation of good faith in its performance." U. C. C. $\$ 1-203$ (Spring 1950).

71 The Code retains existing principles of estoppel. U. C. C. \$I-103 (Spring 1950).

72 "As far as third parties are involved, the acquisition of a proper 'certificate of title' becomes a part of what is statutorily required to satisfy the 'course of trade' within the meaning of the section on good faith purchase of goods." U. C. C. $\$ I-203$, comments 1,2 (Spring 1950).
} 
certificate is not made clear, but presumably the purpose of this section is to require of dealers compliance with regulatory statutes which serve a beneficial commercial purpose to the public. The statutes in Georgia, Iowa, Kentucky, and Minnesota tend to make the registration receipt a valuable source of title evidence to transferees of "ownership" interests, who must obtain or sign the registration certificate. ${ }^{73}$ Therefore, the way is left open for the courts to impose civil sanctions upon dealers who fail to comply under the "good faith" provisions of the Code. This may mean that dealers must take affirmative measures to determine non-security ownership interests reflected upon the registration certificate. ${ }^{74}$ This may mean, too, that in Georgia ${ }^{75}$ lien-sellers must perfect lien interests upon the registration certificate to the extent that failure of the instrument to show such liens will create an estoppel in favor of third persons who rely upon an unencumbered receipt.

\section{III}

\section{Effect of Titue Certificate Laws on General Statutes Providing for Recordation of Liens}

The general problem. A common misunderstanding of the title certificate laws has been the general belief that the effect of such legislation is to make the certificate the sole muniment of ownership. ${ }^{76}$ This the statutes have not done ${ }^{77}$ either by express provision or by judicial decision, although it may not be unreasonable to suggest that the case law is pointing in that direction. ${ }^{78}$ However, the importance of the title certificate as a conduit of title has been recognized in a number of decisions where the document has figured prominently in matters of estoppel. Estoppel may occur in many different ways, but speaking generally, an estoppel arises where the owner entrusts possession to another under circumstances creating an appearance of ownership. Third persons who justifiably rely upon this combination of events may be protected where the person in possession has exceeded the boundaries of his particular ownership interest.

The estoppel situation customarily makes its appearance in business transactions (I) where the owner (in those obscure cases which the law, for one reason or

${ }^{73}$ See App. I, cols. 2, 3.

"Cf. Kirk v. Madsen, 36 N. W.2d 757 (Iowa 1949) (purchase of out-of-state automobile by used car dealer without certificate of title showed lack of good faith); Eline v. Commercial Credit Corp., $307 \mathrm{Ky} .77,209$ S. W.2d 846 (1948) (dealer-buyer required to examine county registration records showing out-of-state certificate of title with encumbrance); Rhode Island Hospital Trust Co. v. Devonshire Financial Service Corp., 53 R. I. 443, I67 Ad. 134 (I933) (bank loaning upon stock in trade denied right to estoppel where no title investigation). Quaere: Whether professional Ienders (who are not required to demand the registration receipt) would be required to inspect the instrument under the Code? But cf. Moberg v. Commercial Credit Corp., 42 N. W.2d 54 (Minn. I950).

${ }^{70}$ This conclusion is drawn from the provisions of the Georgia statute requiring delivery of a certificate of registration upon transfer, and authorizing liens at time of transfer to be registered. While liens may be registered in South Carolina, the statute does not require endorsement of the registration receipt upon transfer.

${ }^{70}$ Cf. Comment, A Comparison of Land and Motor Vehicle Registration, 48 YaLe L. J. 1238 (1939).

${ }^{77}$ E.g., Bank of America Nat. T. \& Sav. Ass'n v. National Funding Corp., 45 Cal. App.2d 320, II 4 P.2d 49, 54-55 (I94I).

${ }^{78}$ Cf. Rigney v. Swingley, II2 Mont. I04, Ix3 P.2d 344 (I94I) (mortgage outside chain of title invalid against subsequent purchaser). 
another, has failed to characterize as a "sale," "conditional sale," or "lien" within the meaning of recording laws) entrusts possession of goods to one engaged in the business of selling or dealing in that type of commodity $;^{70}$ (2) where the seller retains possession after title passes; ${ }^{80}$ (3) where title and possession are obtained as the result of fraud; ${ }^{81}$ and, (4) where one obtains title under a resulting or express trust. $^{82}$ In each of these transactions a bona fide purchaser from the intermediate party in possession is usually protected. ${ }^{83}$ However, in the first transaction the decisions have shown a tendency to protect only the buyer in ordinary course of trade unless other factors are present to indicate a broader power. ${ }^{84}$ In all of these

${ }^{79}$ E.g., W. P. Fuller \& Co. v. Adams, 97 Wash. 254, I66 Pac. 623 (1917). It is perhaps inaccurate to conclude that the mere entrusting of possession to one who deals in, or sells goods of that type will give rise to an estoppel. I Williston, Sales \$314 (2d ed. 1924). But cf. U. C. C. \$2-403 (Spring 1950). Possession coupled with a bill of sale has been held sufficient to create an estoppel. Bailey v. Hoover, 233 Ky. 68r, 26 S. W.2d 522 (1930). But cf. Essex County Acceptance Corp. v. Picrce-Arrow Sales Co., 288 Mass. 270, I92 N. E. 604 (1934) (distributor entrusting automobile and invoicc marked "cash on delivery" not estopped against subsequent lienholder upon ground that invoice not marked "paid").

80 "Where a person having sold goods continues in possession ... the delivery or transfer by that person ... to any person receiving and paying value for the same in good faith and without notice of the previous sale, shall have the same effect as if the person making the delivery or transfer wera expressly authorized by the owner of the goods to make the same." UNIForas SALES ACT \$25. No similar provision is to be found in the Code, except that a buyer in the course of ordinary busincss is protected against one who acquiesces in the possession of goods held by a dealer. U. C. C. $\$ 2-403(2)$ (Spring 1950). Motor vehicle cases dealing with the problem of Section 25 of the Uniform Sales Act: Armstrong v. Boomansour, 223 App. Div. $5 \mathrm{II}, 228$ N. Y. Supp. 722 (4th Dep't 1922), aff'd mem., 252 N. Y. 590, I70 N. E. I55 (r929); Sax Motor Co. v. Mann, 71 N. D. 221, 299 N. W. 691 (1941); cf. Kruse v. Carey, 259 Mich. 157, 242 N. W. 873 (1932) (involving rights of creditors).

${ }^{81}$ As a matter of business experience estoppel of this sort is most commonly invoked where an owner is duped into selling property upon a bad check. See Blount v. Bainbridge, 79 Ga. App. 99, 53 S. E.2d I22 (1949) ("Aly-by-night dealer" gave bad check); White v. Pike, 36 N. W.2d 761 (Iowa 1949) (professional forger passed printed check taken in burglary). In the title certificate states, the seller can guard against bad checks by attaching the endorsed title certificate to the check. Kirk v. Madsen, 36 N. W.2d 757 (Iowa r949); Nelson v. Fisch, 39 N. W.2d 594 (Iowa r949). The Commercial Code repudiates the rule in some states which treats the bad check sale as a "cash sale," thus protecting good faith purchasers in all cases where possession has passed. Compare U. C. C. \$2-40I(1) (Spring 1950) with Young v. Harris-Cortner Co., I52 Tenn. 15, 268 S. W. I25 (1924).

In some states the owner who has been dispossessed of his property under circumstances amounting to common law larceny may reclaim possession from a bona fide purchaser. L. W. Swect \& Co. v. Provident Loan Soc'y of N. Y., 279 N. Y. 540, 18 N. E.2d 847 (1939); Deferred Payment Plan, Inc. v. Bennett, 263 App. Div. 694, 35 N. Y. S.2d I59 (3d Dep't 1942) (owner induced to part with automobile and assign registration in blank as the result of larceny by trick). The Commercial Code repudiates this technical rule where goods are entrusted to a person who deals in goods of that kind. U. C. C. $\$ 2-403(3)$ (Spring, 1950).

${ }^{82}$ Express trusts: 4 Bogert, Trusts and Trusters $\$ 88$ I (1948). Ricsulting trusts: 2 id. $\$ 466$ (1935). For cases involving automobiles, see Lynn v. Herman, 72 Cal. App.2d 6r4, 165 P.2d 54 (1946) (community property); Willard H. George, Ltd. v. Barnett, 65 Cal. App.2d 828, 150 P.2d 59 (I944); Maryland Casualty Co. v. Hollman, xoo Cal. App. 669, 280 Pac. I034 (r929); National Fire Ins. Co. v. Collingsworth, $288 \mathrm{Ky} \cdot 398$, I56 S. W.2d I57 (r94I); Davis v. Grossman, 20r Minn. 156, 275 N. W. 858 (1937); Rigney v. Swingley, II2 Mont. I04, II3 P.2d 344 (194I); Associates Discount Corp. v. Davis Motor Sales, 275 App. Div. 745, 87 N. Y. S.2d 757 (4th Dep't 1949); Majors v. Majors, 349 Pa. 334, 37 A.2d 528 (1944).

${ }^{83}$ See notes $80-82$ stipra.

${ }^{84}$ E.g., Tropical State Bank v. Sunshine Motor Co., 137 Fla. 703, 188 So. 595 (1939) (consignment of automobiles on common-law trust receipt to dealer did not empower him to mortgage property); Jacob E. Decker \& Sons v. Milwaukee Cold Storage Co., r73 Wis. 87, x80 N. W. 256 (1920) (commission agent selling meat had no power to encumber property in his possession); Harrison v. Auto Securities Co., 
cases the rights of creditors against the party in possession vary greatly within the jurisdictions and from state to state. ${ }^{85}$ Unless the state has a factors' act, none of these situations clearly fall within the filing or recording statutes. ${ }^{86}$ And seldom, if ever, does the unwitting owner, who finds himself faced with estoppel, think in terms of recording or filing.

The motor vehicle certificate of title laws have cut deeply into some of these general principles, and have added some others. Unlike recording and filing acts

70 Utah II, 257 Pac. 677 (1927) (buyer from dealer-agent in regular course of business prevailed over finance company holding a lien on vehicle repossessed by dealer). The principle by which a purchaser in ordinary course of trade prevails against an owner who has entrusted possession to a dealer cuts a wide swath in the law. It is imposed against conditional sellers. Uniform Condinonal Sales Acr \$9. A chattel mortgagee holding a lien upon inventory will be defeated by a purchaser in regular course of business. E.g., Helms v. American Security Co., 216 Ind. I, 22 N. E.2d 822 (1939). Likewise in the case of trust receipts. UNIFORM Trust RECEIPTS ACT $\$ 9$.

${ }^{86}$ Dealer in possession. In the absence of legislation, the consignor usually prevails over creditors of the consignce. 2 Garrard Glenn, Fraudulent Conveyances and Preferences $\$ 537$ (Rev. ed. I940). Áside from factoring, however, estoppel constitutes the basis of the law of fraudulent conveyances based upon "reputed ownership." I id. \$343; W. P. Fuller \& Co. v. Adams, 97 Wash. 254, I66 Pac. 623 (19I7) (mother leaving son in possession of machinery used in manufacturing business estopped against claims of creditors); Frick Co. v. Walter Cox Co., ror Ind. App. 402, I99 N. E. 462 (1936) (principal of factor with unlimited power of sale and no duty to account for proceeds estopped against creditors).

Seller in possession. In most states creditors who advance credit in reliance upon the seller's apparent ownership, and who become lien creditors before the buyer takes possession, prevail over the latter. I Glenn, Fraudulent Conveyances and Preferences c. I9 (Rev. ed. 1940); cf. Kruse v. Carey, 259 Mich. 157,242 N. W. 873 (1932). Like the prior Uniform Sales Act, the Commercial Code leaves the rights of creditors of the seller to be determined by local law, except that retention of possession "in good faith and current course of trade by a merchant-seller for a commercially reasonable time" is not fraudulent. U. C. C. \$2-402 (Spring 1950).

Possession obtained by frand. The owner is usually permitted to prevail against creditors of one who has obtained title and possession by fraud. E.g., California Conserving Co. v. D'Avanzo, 62 F.2d 528 (2d Cir. 1933); cf. Federal Building Co. v. Ford Motor Co., ror Ind. App. 286, I99 N. E. I63 (1936) (manufacturer who delivered automobiles and invoices marked "paid" upon a bad check of dealer not estopped against subsequent creditor claiming an "equitable" lien); U. C. C. \$2-702 (Spring, 1950) (recognizing right of reclamation by seller where buyer has misrepresented solvency in writing within three months before delivery).

Resulting or express trust. Creditors of the trustec, as a general rule, will prevail only where other elements of estoppel are present. I BogerT, TRUST AND TRUstees \$I46 (1935); 2 id. \$466; Willard H. George, Ltd. v. Barnett, 65 Cal. App.2d 828, 150 P.2d 591 (r944) (mother took title of daughter's vehicle in her name-creditors of mother who did not grant credit on strength of title defeated by claim of daughter); Bolton-Swanby Co. v. Owens, 201 Minn. 162, 275 N. W 855 (1937) (bailee's creditors could not claim estoppel where automobile registered in bailee's name, since claims arose before registration); Bosen v. Larrabee, 9I N. H. 492, 23 A.2d 33 I (I94I) (owner prevailed against creditor of bailee in whose name vehicle registered, on ground that creditor was notified of ownership before levy); Majors v. Majors, $349 \mathrm{~Pa}$. 334, 37 A'.2d 528 (1944).

${ }^{80}$ Sandack v. Tamme, I 82 F.2d 759 (roth Cir. 1950). Twenty-one states have adopted factors' acts which are variously limited in scope, and chiefly directed to the protection of the lien of the factor out of possession. Silverman, Factoring: Its Legal Aspects and Economic Justification, 13 LAw \& ConteMp. Prob. 592 (1948) (statutory provisions charted at pp. 602-603); Note, An Examination of the Minnesota Factor's Lien Act, 34 Mrns. L. Rev. 199 (1950). In Virginia, the Traders' Act does not apply to liens perfected upon a certificate of title. VA. CodE ANN. \$46-7I (1950); Universal Credit Co. v. Botetourt Motor Co., I 80 Va. 159, 2 I S. E.2d 800 (1942). In Royle v. Worcester Buick Co., 243 Mass. I43, I37 N. E. 53I (I922) the New York Factors' Act was not applied to an agent in possession of his principal's motor vehicle with authority to solicit offers, on the ground that he was not authorized to make a sale.

Several states (Iowa, Kentucky, Maryland, and Washington) have statutes permitting recording of the buyer's contract where the seller is left in possession. I Wilirston, SALEs $\$ \$ 368,370,373,401$ (2d ed. 1924); Cerex v. Peterson, 203 Iowa 355, 212 N. W. 890 (1927); Fields-Watkins Co. v. Hensley, II7 Va. 661,86 S. E. I13 (I915). 
which permit only liens to be shown upon the public records, these statutes anticipate a showing of the final link in the whole chain of transfers relating to each motor vehicle. Unfortunately, none of the title laws state in so many words that the ownership certificate constitutes constructive notice of title interests to third persons. Though some of the statutes do permit liens to be shown through this instrumentality and expressly state that such liens constitute constructive notice to third parties, most statutes merely make non-compliant transfers illegal, or in various ways express that they are "void."" In Florida, Idaho, Nebraska, and Ohio, the statutes literally provide that no interest shall be acquired by estoppel against a person having possession of the certificate of title. ${ }^{88}$

In brief, the title certificate laws have had this general effect: ( 1 ) Purchasers who would otherwise qualify to receive the benefits of an estoppel are defeated when the owner retains the certificate of title. ${ }^{89}$ In other words, acquisition of title interests by estoppel is forbidden because the statutes compel purchasers to obtain an assignment of the instrument and comply with the title certificate laws. Some difficulty arises here, however, because only transferees of "ownership" interests are literally compelled to comply with such laws. ${ }^{90}$ Creditors, $^{91}$ and possibly lienholders, ${ }^{92}$ do not come within the mandatory direction of the statutes. But since the title certificate and the title records provide a statutory, common, and reliable source of title information, there is no good reason why creditors and lienholders should not be compelled to consult the records in order to show good faith or reasonable reliance. (2) Purchasers who otherwise would not qualify to receive the benefits of an estoppel may do so when the person in possession of the property is given a clear certificate of title. ${ }^{93}$ This means, for example, that a bailee in possession

${ }^{87}$ See App. 2, col. I; App. 3, col. I. The language of the statutes in several states, howcver, is broader. E.g., "No person acquiring a motor vehicle from the owner . . . shall acquire any right, title, claim, or interest in or to said motor vehicle until he shall have had issued to him a certificate of title. ..." Oho COde ANN. \$6290-4 (1945); Fra. Stat. ANv. \$319.22(r) (1949); IdAHo Code ANN. \$49-404 (I948); Neb. Rev. Stat. \$60-rio (r943).

${ }^{88}$ See App. 3, col. I. Cf. Tex. Stat., Penal Code art. 1436-ז, $\$ 44$ (1948). Sec note 87 supra.

${ }^{80}$ Estoppel denied purchaser in regular course of trade who did not get certificate of title: Wilson $v$. Mosko, I10 Colo. I27, I30 P.2d 927 (1942); Lux v. Lockridge, 65 Idaho 639, 150 P.2d 127 (1944); cf. Sax Motor Co. v. Mann, 7I N. D. 221, 299 N. W. 691 (1941); Nash Miami Motors, Inc. v. Bandel, I60 Fla. 925, 37 So.2d 366 (I948). But cf. Mason v. Shelton, 292 Ill. App. 640, II N.E.2d 224 (1937). Purchaser from one holding possession of vehicle by fraud against owner denied bencfit of estoppcl because of failure to acquire certificate: Nelson v. Fisch, 39 N. W.2d 594 (Iowa 1949) (bad check); Kirk v. Madsen, 36 N. W.2d 757 (Iowa 1949) (bad check); Sims v. Sugg, I65 Kan. 489, I96 P.2d I91 (1948) (bad check); Pearl v. Interstate Securities Co., 357 Mo. I6o, 206 S. W.2d 975 (1947) (bad check); Wills v. Shepherd, 23I S. W.2d 843 (Mo. App. I950) (bad check); Deahl v. Thomas, 224 S. W.2d 293 (Tex. Civ. App. 1949).

${ }^{\circ}$ See notes 18,30 supra.

${ }^{01}$ In re Soss, 52 F. Supp. I23 (D. Del. I943); Kruse v. Carey, 259 Mich. 157, 242 N. W. 873 (1932). But cf. Coca Cola Bottling Co. v. Feliciano, 32 Cal. App.2d 35I, 89 P.2d 686 (1939).

${ }^{22}$ Most of the statutes do not in terms require lienholders to perfect the lien upon the certificate as against prior parties. See App. 3, col. 5. Cf. Peper v. American Exchange Nat. Bank, 357 Mo. 652, 210 S. W.2d 4I (I948); Elder Chevrolet Co. v. Bailey County Motor Co., 15I S. W.2d 938 (Tex. Civ. App. I94x) (subsequent lienholder who did not perfect lien on title prevailed over prior lienholder who failed to do the same).

${ }^{83}$ E.g., Commercial Finance Corp. v. Burke, r73 Ore. 34r, I45 P.2d 473 (I944). Creditors, too, may claim an estoppel when a debtor is put in possession with a proper title certificate. Majors v. Majors, 
has the power to transfer title to third persons when he holds both an unencumbered title certificate and possession of the vehicle, though he ordinarily does not have such power. ${ }^{94}$ To this extent the statutory title instrument gives to him an appearance of ownership which may be relied upon by third parties. In these cases, most of the decisions hinge upon the presence or absence of the certificate of title, not because the instrument serves as constructive notice, but upon the ground of estoppel created by a statutory standard. Whether a purchaser from one with possession and the necessary certificate will be protected against the owner when he has not affirmatively relied upon the certificate has never been clearly decided, but the tendency has been to deny estoppel unless the certificate is seen or properly assigned. ${ }^{95}$ (3) The title certificate is not the sole source of title, ${ }^{96}$ although both possession of the vehicle and possession of a properly endorsed certificate of title combine to create an estoppel. ${ }^{97}$ Consequently third persons can rely neither upon possession of the vehicle alone, nor upon possession of a certificate of title alone, as a basis for claiming estoppel against one who relinquishes possession of one or the other. This follows from the statutory scheme of the legislation, which is to make the title certificate a necessary accessory to every motor vehicle. In this respect the title certificate serves the purpose of a limited document of title which, like a filed or recorded instrument, gives notice of non-possessory title interests only.

Under the Uniform Commercial Code. Without going into detail, it is sufficient to point out that the sales provisions of the Commercial Code promise to introduce some new problems into the field of estoppel. The old concept of passage of "title" has been broadened.98 Consignment sales may now qualify as "security interests"

$349 \mathrm{~Pa} .334,37 \mathrm{~A} .2 \mathrm{~d} 528$ (r944) (W paid for auto, title to which was taken in $H$ 's name-held this rebutted presumption of resulting trust); $c f$. Washington Lumber \& M. Co. v. McGuire, 2 r $_{3}$ Cal. 13 , I P.2d 437 (193I). But cf. Wargin v. Wargin, 29 Cal.2d 843, I80 P.2d 349 (1947) (bill of sale transferred to mortgagee as owner). However, if the creditor does not advance credit in reliance upon both possession and the certificate, the owner out of possession will prevail. Willard $H$. George, Ltd. v. Barnett, 65 Cal. App.2d 828, I50 P.2d 59I (1944); cf. Bosen v. Larrabeex 9 I N. H. 492, 23 A.2d 23 I (r93I) (under registration statute). When grounds for estoppel would otherwise be present, the fact that the purchaser acquires a clear certificate of title may play a decisive role in determining the rights of the parties. Kelsoe v. Krouskay, 70 Ariz. 152, 217 P.2d 915 (1949) (bad check); Shockley v. Hill, 9r Colo. 45I, 15 P.2d 623 (1932) (bad check); Dresher v. Roy Wilmeth Co., I1 8 Ind. App. 542, 82 N. E.2d 260 (1948) (bad check). However, if possession of the certificate of title is obtained from the owner by theft, estoppel will not operate in favor of a third party. Adkisson v. Waitman, 213 P.2d 465 (Okla. 1949) (wife appropriated title assigned in blank); cf. Swartz v. White, 8o Utah I50, I3 P.2d 643 (1932) (purchaser from agent in possession of the vehicle and title assigned in blank did not prevail over owner, on ground that certificate was not in agent's name).

${ }^{\circ}$ E.g., Rice v. Galkowski, 333 Ill. App. 652, 77 N. E.2d 889 (1948).

${ }^{\text {or }}$ Cf. Willard H. George, Ltd. v. Barnett, 65 Cal. App.2d 828, I50 P.2d 591 (1944); Sims v. Sugg, I65 Kan. 489, I96 P.2d I9I (1948) (owner defrauded by purchaser who gave bad check prevailed against third person, although fraudulent purchaser held certificate of title which had not cleared through motor vehicle agency).

${ }^{\circ 0}$ E.g., Henry v. General Forming, Ltd., 33 Cal.2d 223, 200 P.2d 785 (1948) (BI put name on list for new vehicles and sold his purchase rights to $B_{2}$-held that creditors of $B_{1}$ could not reach vehicle where possession in $B 2$, though title in $B \mathrm{r}$ ). But cf. Coca Cola Bottling Co. v. Feliciano, 32 Cal. App.2d 351,89 P.2d 686 (1939). In general see cases cited at note 214 infra.

or See note 93 supra.

${ }^{\text {os }}$ Principal changes relevant to the discussion here are that (a) reservation by the seller of the title in goods delivered or otherwise identified to a contract is limited in effect to "security"; (b) good faith purchasers from a buyer under a "cash sale" are protected, U. C. C. \$2-40I(I) (Spring I950); (c) upon insolvency, the seller may refuse delivery, except for cash. Id. \$2-702. 
within Article 9 of the Code. 99 "Buyers in the ordinary course of business" from one to whom goods have been "entrusted" by "delivery and any acquiescence in retention of possession" are the chief group protected by specific provision for estoppel in sales transactions. ${ }^{100}$ But the Code in its general provisions retains the "principles of law and equity, including . . . estoppel,"101 and imposes "an obligation of good faith" upon the parties to every contract within its scope. ${ }^{102}$ Probably the two most significant changes relevant to the title certificate problem arise out of the protection afforded "buyers in the ordinary course of business," and the "good faith" requirement.

Editorial comment to the "good faith" section states:103

As far as third parties are involved, the acquisition of a proper "certificate of title" becomes a part of what is statutorily required to satisfy the "course of trade" within the meaning of the section on good faith purchase of goods.

In literal effect this means that dealers and, perhaps, lending institutions must comply with the title certificate requirements for protection against both subsequent and previous parties. Therefore, in so far as "professionals" are concerned, the title certificate serves as a form of constructive notice of all outstanding interests, since the "professional" in sales, and probably in security transactions, must deal through the title instrument. The policy of this intent seems sound, except for the obscure way in which it appears. However, it is likely that some of the title certificate laws are not encompassed within the Article on Secured Transactions, which adopts the title certificate machinery as a means for imparting constructive notice of liens. ${ }^{10 t}$ These title certificate laws impose neither civil nor criminal sanctions on transferees other than those acquiring "ownership" interests which are defined to exclude lien interests. ${ }^{105}$ Consequently, there may be some doubt whether bankers must examine the title certificate before making loans. ${ }^{106}$ An intent on the part of the Codifiers to impose this, as a good faith requirement, upon professional lenders is not certain, because the reference in the Comments is to a statutory standard of good faith. ${ }^{107}$ Existing authority provides no conclusive standard for predicting how the courts will resolve that doubt. ${ }^{108}$

99 "Transactions in the form of consignments or leases may be security transactions subject to this Article if the understanding of the parties or the effect of tho arrangement shows that a security interest was intended." U. C. C. \$9-102, comment I (Spring 1950). However, consignment transactions upon "sale or return" are expressly preserved, but the rights of the seller will be defeated as against the creditors of the buyer ". . . unless the seller complies with any applicable law requiring a consignor's interest or the like to be evidenced by a sign or establishes that the buyer is known to be primarily engaged in selling the goods of others." Id. $\$ 2-326$. Buyers in the ordinary course of business are protected. Id. $\$ 2-403$.

100 U. C. C. $\$ 2-403$ (Spring 1950).

${ }^{202}$ U. C. C. $\$ \mathrm{I}-203$ (Spring I950).

${ }^{104}$ U. C. C. $\$ 9-402$ (Sept. 1950).

${ }^{106}$ See notes, 108 infra, 92 supra.

${ }^{101}$ U. C. C. $\$ 1-103$ (Spring 1950).

${ }^{103}$ U. C. C. $\$ \mathrm{r}-203$, Comment 2 (Spring 1950).

${ }^{105}$ See notes 18,30 supra.

${ }_{102}$ U. C. C. $\$ 1-203$, comment 2 (Spring 1950).

${ }^{108}$ Compare Nash Miami Motors, Inc. v. Bandel, 47 So.2d 7or (Fla. 1950) (lending bank charged with notice of consignor's interest shown by title certificate) with Moberg v. Commercial Credit Corp., 42 N. W.2d 54 (Minn. 1950) (lending bank not charged with constructive notice of consignor's interest shown by registration certificate). 
Considerable difficulty stems from the categorical protection given the "buyer in ordinary course of business" by the Code..$^{109}$ The problem may be posed simply. Suppose $O$ entrusts a motor vehicle to $D$, a dealer in motor vehicles, giving him authority to solicit offers. $O$ sells to $B$ from his lot, but $B$ fails to get the necessary title papers which are in $O$ 's hands. Literally the Code protects the purchaser, $B$, unless, of course, the transaction is treated as a "security transaction," which is doubtful. ${ }^{110}$ This Code result is supported by Commercial Credit Co. v. McNelly, ${ }^{111}$ a Delaware decision grounded upon the statute in that state which imposed no civil sanctions upon purchasers who failed to comply. In Colorado, Wilson v. Mosko $o^{112}$ reached the opposite conclusion. ${ }^{113}$ The policy of the Code is sound, especially in view of the deficiency in the title laws which give to dealers broad privileges under the statutes. ${ }^{114}$ It is doubtful, however, that the Code provision extends to the casual customer who leaves a vehicle for repairs with a garageman who also sells used cars, a situation which arose in Winship v. Standard Finance Company. ${ }^{115}$

Certificate of title laws as imparting constructive notice of liens. Clarification of the role of the various title certificate laws imparting constructive notice of liens has been only partially achieved by the case law upon the subject. While many of the states have express provisions to the effect that local filing statutes are superseded by title laws, nearly half of the jurisdictions have left the matter for judicial settlement which, because of constant legislative revision, is far from conclusive. The methods by which the lien must be perfected are expressed by technical provisions which require the lien to be enter ${ }^{\circ}$ both upon the certificate and the records of the proper administrative agency. Formal non-compliance has led to considerable inconsistency in the case law, especially in those cases where the lienholder retains possession of the instrument, or causes it to be registered in his name as owner. Uniformity has not been achieved in defining the rights of third persons. And finally, the decisions have followed a winding path through the literal maze of the statutory language in defining the security transactions encompassed by the laws, leaving much confusion, especially in the area of dealer financing.

Effect of title certificate laws on general filing or recording statutes. As previously pointed out, most of the 26 states with comprehensive title certificate legislation explicitly provide that constructive notice of liens must be achieved through the certificate of title to the exclusion of general filing or recording statutes. ${ }^{116}$ The case

${ }^{100}$ U. C. C. $\$ 2-403$ (Spring 1950).

${ }^{210}$ U. C. C. $\$ \mathrm{I}-20 \mathrm{r}(36)$ (Spring 1950).

2116 Harr. 88, x7I Atl. 446 (Del. Super. Ct. 1934).

212 I 10 Colo. I27, 130 P.2d 927 (1942).

113 For other cases, see note 89 supra.

${ }^{214}$ Cf. Nicewarner v. Alston, 228 S. W.2d 872 (Tex. Civ. App. 1950) (sale between dealers not governed by statute which did not apply to "first sale"). In general, see App. 2, col. 5; App. 3, col 9. ${ }_{1116} 40$ Ariz. 382, I2 P.2d 282 (1932) (subsequent lienholder who received forged title certificate defeated).

${ }^{210}$ See App. 3, col. 6. The states are Arizona, Arkansas, California, Colorado, Delaware, District of Columbia, Florida, Idaho, Louisiana, Missouri, Montana, Nebraska, Nevada, Ohio, Tennessee, Texas, Utah, and Virginia. 
law in these states would appear to have clearly verified this conclusion. ${ }^{117}$ However, the statutes of Kansas, Michigan, New Jersey, New Mexico, Oregon, Pennsylvania, Washington, and Wyoming do not verbally purport to repeal the local recording laws, ${ }^{118}$ and most of this group also fail to define the rights of third parties whether or not the liens are properly noted upon the certificate of title. ${ }^{110}$ But despite this omission, the general comprehensive nature of these laws indicates that they must have been adopted to accomplish a useful purpose. Since machinery for recording liens with a central motor vehicle department and noting liens upon the title instrument is clearly provided, one must strain to suppose that the legislatures intended to provide two separate places for public notice of liens. Consequently, the tendency of the courts in these states has been to hold that liens must be shown upon the title certificate for protection against third parties, and that the local records are closed to motor vehicle liens. ${ }^{120}$ A contrary construction was rejected in a very recent Kansas decision, General Acceptance Corporation v. Davis, ${ }^{121}$ where the claims of a bona fide purchaser were recognized over a conditional seller who had filed his lien in the county records but not upon the certificate of title. The court said,

... any person, member of the public generally, or a dealer in used cars, had the right to purchase from [the conditional buyer] upon satisfying himself that the certificate of title correctly identified the automobile being purchased, and to rely upon the certificate of title that there was no lien or encumbrance thereon.

It will be noted, however, that the language of the court is an expression of "estoppel" rather than of "constructive notice." For this reason, the precise effect of the legislation in most of these states remains in serious doubt.

Decisions in the states with "incomplete" certificate of title laws, Illinois, Indiana, Maryland, North Carolina, North Dakota, South Dakota, West Virginia, and Wisconsin, ${ }^{122}$ have been inclined to hold that such statutes have had no effect on other recording requirements. ${ }^{123}$ Some support for this position can be found by reasoning

${ }^{117}$ E.g., In re Wiegand, 27 F. Supp. 725 (S. D. Cal. 1939); Consumers Credit Co. v. Manifold, 65 Idaho 238, I42 P.2d. 150 (I943); Rigney v. Swingley, II2 Mont. I04, II3 P.2d 344 (I94I); State v. Taggart, 133 Ohio 382, I4 N. E.2d 10 (1938); Christian v. Boyd, 222 S. W.2d 157 (Tex. Civ. App. I949).

${ }^{218}$ See App. 3, col. 6.

119 The particular rights of third parties are not described in Kansas, Michigan, New Jersey, Oregon, Washington, and Wyoming. See App. 3, col. 5.

${ }^{120}$ Van Syckle v. Keats, r25 N. J. L. 319, 15 A.2d 321 (Sup. Ct. 1940) (conditional scller who pcrfected lien through certificate of title protected without local recording); In re Berlin, 147 F.2d $49 x$ (3d Cir. 1945) (lien perfected on certificate of title valid against trustee in bankruptcy); cf. Daas v. Contract Purchase Corp., 318 Mich. 348, 28 N. W.2d 226 (1947) (purchaser in course of trade who received clear certificate of title prevailed over recorded mortgage); Larison-Frces Chevrolet Co. v. Payne, 163 Ore. 276, 96 P.2d 1067 (r939) (owner could not pass marketable title where certificate outstanding); First National Bank v. Sheldon, 16r Pa. Super. 265, 54 A.2d 6I (1947); Automobile Banking Corp. v. Weicht, 160 Pa. Super. 422, 51 A.2d 409 (1947).

${ }^{121}$ I69 Kan. 220, 218 P.2d I8I, I83-184 (I950).

122 See App. 2.

${ }^{123}$ Nelson v. Viergiver, 230 Mich. 38,203 N. W. I64 (1925) (mortgage shown on title, but not recorded); General Credit Corp. v. Lee James, Inc., 8 Wash.2d 185, III P.2d 762 (I941) (mortgagee who failed to obtain possession of certificate prevailed over prior mortgagee holding certificatc of title); $c$. 
that if the legislature intended to provide a new system for imparting constructive notice of liens it would have said so, and also if the statutes were intended to provide constructive notice to third persons, the legislature would have particularly defined the rights of creditors, subsequent purchasers, and lienholders. Thus a pioneer North Carolina decision ${ }^{\mathbf{1 2 4}}$ denied priority to a conditional seller whose lien was duly perfected upon the certificate of title, but not upon the records. There the court reasoned that since penal sanctions were imposed upon the purchaser who failed to get the title, the legislature must have intended to work no change in the civil rights of the parties. On the other hand, some authority will be found which has given effect to the certificate of title as a means of constructive notice under such laws. In Washington ${ }^{125}$ and Indiana, ${ }^{126}$ decisions have protected purchasers obtaining a clear certificate of title against the claims of prior lienholders whose liens were preserved by filing or other principles of law. Usually these decisions are grounded upon estoppel, where possession coupled with a certificate of ownership in the lien-debtor create an appearance of ownership. It would seem that if estoppel is to be applied in these cases, there is no reason why it should not also govern to defeat the rights of third persons who fail to examine the status of the instrument where the lien is properly noted on the certificate. ${ }^{127}$ This finds general support in the practice of the public and the automobile industry in their reliance upon the certificate as a means for determining both ownership and lien interests. ${ }^{128}$ Legal

L. B. Motors, Inc. v. Prichard, 303 Ill. App. 313, 25 N.E.2d I29 (I940) (buyer in regular course of trade prevailed over lienholder who retained certificate); Community State Bank v. Crissinger, 89 N. E.2d 78 (Ind. App. 1949) (mortgage recorded, but not shown upon certificate); Owen v. Miller, r9o Okla. 205, 122 P.2d 140 (1942) (purchaser in regular course of trade who did not obtain certificate prevailed over mortgagee who had recorded in local records and kept possession of certificate); see Meyer Herson Auto Sales Co. v. Faunkhauser, 65 F.2d 655, 656 (D. C. App. I933); In re Rosen, 23 F.2d 687 (D. Md. 1928) (". . . it is conceded by counsel for the petitioner and it is the opinion of this court that such registration does not take the place of the recording of liens. ...").

${ }^{224}$ Carolina Discount Corp. v. Landis Motor Co., I90 N. C. 157, r29 S. E. 414 (1925).

${ }^{125}$ Merchants Rating \& Adjusting Co. v. Skaug, 4 Wash.2d 46, 102 P.2d 227 (1940) (purchaser who obtained a clear title prevailed over mortgagee who had recorded locally).

${ }^{120}$ Superior Finance Co. v. American Security Co., ro7 Ind. App. 46r, 25 N. E.2d 256 (I940); $c$. Guaranty Discount Corp. v. Bowers, 94 Ind. App. 373, 158 N. E. 231 (1932) (buyer in regular course of trade who got clear certificate of title prevailed over conditional seller). In Nichols v. Bogda Motors, Ir 8 Ind. App. 156, 77 N. E.2d 905 (1948), a subsequent Indiana purchaser prevailed over a Michigan mortgagee who had filed in Michigan, but had not had his lien noted upon the title. The court refused to give effect to the Michigan mortgage upon the ground that it was against the "established policy" of the state of Indiana, although the mortgage would have been valid in Michigan. The same judge, however, may have reversed the "policy" in the Community State Bank v. Crissinger, 89 N. E.2d 78 (Ind. App. 1949).

${ }^{227}$ Cf. International Harvester Co. y. Holley, xo6 Ind. App. 329, I8 N. E.2d 484 (1939) (conditional seller who retained title prevailed over creditors of buyer); Eline v. Commercial Credit Corp., $307 \mathrm{Ky}$. 77, 209 S. W.2d 846 (1948) (Kentucky buyer charged with notice of Indiana conditional seller who had noted lien upon certificate); Universal C. I. T. Credit Corp. v. Walters, 230 N. C. 443, 53 S. E.2d 520 (r949) (Illinois conditional seller noted lien on certificate, and prevailed over North Carolina creditors); Chandler v. Conabeer, I98 N. C. 757,153 S. E. 313 (1930) (mortgagee who did not file locally but retained certificate of title prevailed over subsequent purchaser who was informed that mortgagor did not have title); Schiefer v. Schnaufer, 7r Ohio App. 43I, 50 N. E.2d 365 (1943) (Indiana mechanic's lien not perfected on certificate defeated by Ohio purchaser under special Ohio statute); People's Finance \& Thrift Co. v. Shirk, 74 P.2d 379 (Okla. I937).

${ }^{128}$ See Commercial Credit Corp. v. Dassenko, 43 N. W.2d 299, 304 (N. D. 1950); Note, 25 IND. L. J. $337,338-339$ (1950). 
recognition of this practice would eliminate the expense and time involved in the search of local records, and give to purchasers and lenders a convenient source of title information. While the general effect of these title certificate laws as imparting constructive notice remains in doubt, the way is left clear in most of the states to give the legislation sensible interpretation. The title certificate machinery is complete enough to impart notice of liens, so that the courts would be justified in construing the legislation as accomplishing an implied repeal of the general filing laws with respect to the manner of imparting public notice. As to the rights of creditors, purchasers, and other lienholders, no reason appears why the general recording laws should not remain applicable.

The problem of whether local recording statutes have been superseded by the title certificate legislation is further accentuated by the peculiar language found in the "incomplete" title states and in New Jersey. There, the procedure for noting liens upon the certificate apparently is confined to those liens incurred or in existence at the time of transfers of "ownership," thus literally excluding the machinery for registering the isolated mortgage or lien. ${ }^{129}$ As a result, several decisions will be found where general filing provisions controlled the rights of third persons upon this narrow ground. Such a decision is found in the case of Community State Bank $v$. Crissinger ${ }^{130}$ where the Indiana Appellate Court upheld a mortgage filed in the county chattel mortgage records against a bona fide purchaser who had received an unencumbered certificate of title. A similar interpretation has been consistently followed in New Jersey, ${ }^{131}$ and in Pennsylvania ${ }^{132}$ under a similar statute since amended to include all types of security transactions. ${ }^{133}$ It may be doubted whether this, as one of several literal construction possibilities, conforms to the general purpose of such legislation. It would appear that this constitutes judicial abortion of a legislative effort to give birth to a new source of complete title information. Since a method is outlined for noting liens upon a genuine transfer of "ownership," there is no mechanical reason why an inferior kind of transfer of security interests should be denied. Furthermore, there is ample authority in other fields of law ${ }^{134}$ to permit a nominal re-transfer or re-issue by the parties to the lien transaction.

\footnotetext{
${ }^{129}$ States with such provisions: Illinois, Indiana, Maryland, North Carolina, North Dakota, South Dakota, West Virginia, Wisconsin. See App. 2, col. 1. New Jersey. See App. 3, col. 2.

${ }_{130} 89$ N. E.2d 78 (Ind. App. 1949); Note, 25 IND. L. J. 337 (1950).

${ }^{131}$ Security National Bank v. Bell, I25 N. J. L. 640, I7 A.2d 552 (Err. \& App. 194I); cf. Buttinghausen v. Rappeport, 13r N. J. Eq. 252, 24 A.2d 877 (Ch. 1942). Since these decisions, the New Jersey statute has been amended, and now applies to any "contract," defined to mean a "conditional sale agreement, bailment, leasc, chattel mortgage, trust receipt or any other form of security or possession agreement, wherein and whereby possession of a motor vehicle is delivered to the buyer. ..." (Italics supplied.) N. J. Stır. Ans. \$39:10-2 (Supp. 1949). Quaere: Whether statute applies to lien incurred without a sale?

132 Taplinger v. Northwestern Nat. Bank, ror F.2d 274 (3d Cir. 1939).

${ }^{133}$ P.. Stat. Ans. tit. 75, §33(b) (Supp. 1949); cf. In re Berlin, 147 F.2d 491 (3d Cir. 1945); First National Bank v. Sheldon, 16I Pa. Super. 265, 54 A.2d 6r (1947) (statute validates chattel mortgages previously not recognized by Pennsylvania law).

${ }^{136}$ Probably the best illustration is the use of the "straw-man" in real estate conveyance where transfers, otherwise not permitted, may be accomplished. E.g., cf. Holt v. Holt, 185 Tenn. I, 202 S.W.2d $65^{\circ}$ (1947); Bochringer v. Schmidt, 254 N. Y. 355,173 N. E. 220 (1930).
} 
Under the Uniform Commercial Code. By stipulating that motor vehicle liens shall be perfected through the title certificate where the statute provides for "registration of all liens on certificates of title," ${ }^{, 135}$ the Code will leave a practical hazard to lenders in many states. Of the doubtful title certificate jurisdictions, ${ }^{136}$ it is reasonably safe to conclude that this section of the Code will apply to Kansas, Michigan, New Mexico, Oregon, Pennsylvania, Washington, and Wyoming, in so far as their statutes generally provide for registration of all liens upon the certificate of title. $^{137}$ However, case law in many of these states has not yet settled whether the statutes were intended to impart exclusive constructive notice of liens, and the Code does not reckon with this situation. Because it does not, it may be assumed that the omission was intentional.

As to the place for perfecting liens upon motor vehicles, confusion is clearly invited in the states with "incomplete" certificate of title laws and New Jersey. The language of such statutes apparently provides that only liens existing at the time of transfer may be registered upon the certificate. Furthermore judicial construction of such statutes is inconclusive, with the exception of Indiana where an intermediate court has held that liens isolated from transfers cannot be entered upon the certificate. ${ }^{138}$

It is suggested that the solution to this problem would be relatively simple. Since adequate machinery for making the certificate the instrumentality for imparting notice of liens has been provided in every title certificate state, elimination of the word "all" would solve the problem. This, too, would extricate ambiguity from the statute in a place where it should not exist, in as much as every motor vehicle lender has a vital interest in knowing where the lien should be perfected.

Requirement that lien be registered with motor vehicle agency. As against third parties, the effective date of the lien is variously fixed at the time of application or filing or when the lien is noted upon the certificate of title by the central motor vehicle department in 20 of the title certificate states. ${ }^{139}$ Of these, Arizona, Arkansas, and Utah provide a ten day period of grace from the time of execution, and in New Mexico the lien becomes effective at the time the application is mailed. ${ }^{140}$ But since all of the states contemplate that the application must channel through the proper department, which in turn is required to note or show the lien upon the certificate, ${ }^{141}$

${ }^{135}$ U. C. C. $\$ 9-402$ (Sept. 1950).

${ }^{130}$ See notes 116, Ir8 supra.

${ }^{137}$ However, to the extent that these statutes do not provide for inventory liens, there remains the possibility that the liens must be filed under the general filing provisions of the Code. Discussion upon this subject will be found in the subsequent pages.

${ }_{138}^{13}$ See notes 130-133 supra.

${ }^{130}$ Arizona, Arkansas, California, Colorado, Delaware, District of Columbia, Florida, Idaho, Louisiana, Missouri, Montana, Nebraska, Nevada, New Mexico, Ohio, Pennsylvania, Tennesssee, Texas, Utah, Virginia. See App. 3, col. 4.

${ }^{140}$ In California the lien of the conditional seller apparently attaches at the time of mailing. Cat. Vemicle Code ANN, \$I86 (1948).

${ }^{141}$ In Nebraska and Ohio, liens upon inventory of new automobiles are perfected at the time possession of the manufacturer's certificate is delivered to the lienholder. In Louisiana such liens are perfected from the time the lien instrument is filed, without noting upon a certificate. See App. 3, col. 4 . 
it may be fair to assume that the statutes fix the effective date of the lien at the time of notation upon the certificate and entry in the records of the proper agency.

To the lienholder, and especially the professional lending agency, the requirement that the lien clear through the central department charged with administration of the certificate legislation constitutes somewhat of a nuisance for the reason that time and expense are consumed by the menial task of mailing or otherwise presenting the necessary papers for clearance and recordation. ${ }^{142}$ Consequently, a substantial number of cases will be found where the lienholder, instead of complying with the formalities of the statute, has taken possession of the title instrument in the conspicuous belief that lack of possession in the lien-debtor constitutes adequate constructive notice to the world that his ownership is not absolute. ${ }^{143}$ With the exceptions of New Jersey and Wisconsin, where possession of the certificate or a duplicate must be retained by the owner in possession, ${ }^{144}$ legislation in none of the states makes this procedure illegal. ${ }^{\mathbf{1 4 5}}$ On the other hand, the statutes do not purport to validate this type of constructive notice, and as previously pointed out, many of the states affirmatively require technical compliance as a condition precedent to constructive notice against third persons.

It is not uncommon for a seller who retains a security interest in the vehicle to keep title in his own name until the conditions of the lien have been performed. ${ }^{140}$ While this procedure is somewhat similar to the situation where the lienholder keeps possession of the certificate, several characteristics of the transaction should be noted. In the first place, the records of the motor vehicle department affirmatively show that the lienholder has an interest in the motor vehicle, so that the public has a positive means for determining who, and what his interest is. Secondly, statutes in practically

242 "The present policy of some financing agencies is to file on only about 25 per cent of cvery 1000 transactions. The filing fees on the remaining 75 per cent are then put in reserve against filing loss and subsequently result in a sizable source of income." AMERican Bankers Ass'N Bank Manual on AutoMOBILE Finanating 36 (194I).

${ }^{143}$ E.g., In re Soss, 52 F. Supp. I23 (D. Del. 1943); Associates Inv. Co. v. National City Bank, 23 I S.W.2d 66r (Tex. Civ. App. 1950); of. Superior Finance Co. v. American Security Co., roy Ind. App. 46r, 25 N. E.2d 256 (r940) (rider attached to certificate of title showing liens, and delivered to - debtor).

I44 N. J. Stat. ANN. $\$ \$ 39: 10-6,39: 10-$ I I (Supp. 1949) (duplicate copy issued to owner in possession who must keep it with automobile); Wis. Acts 1949, c. 1949, \$85.0I(3a) (certificate must be in possession of owner). Where possession of the bill of sale was relinquished to a mortgagee, the New Jersey Court held the lien invalid against a subsequent purchaser. Buttinghausen v. Rappeport, I3I N. J. Eq. 252, 24 A.2d 877 (Ch. I942).

${ }^{145}$ Littell v. Brayton Motor \& Accessory Co., 7o Colo. 286, 201 Pac. 34 (1921) (mortgage valid between parties, and against subsequent lienholder with notice); Chandler v. Conabeer, 198 N. C. 757,153 S. E. 313 (1930); cf. In re Senetos, 29 F.2d 854 (D. C. Cal. 1928) (transfer of "title or intcrest" did not include mortgage).

${ }^{146}$ E.g., Coffey v. Williams, 69 Ariz. 126, 210 P.2d 959 (1949) (mortgagor endorsed certificate of title to mortgagee who caused it to be transferred on the records-held parol evidence admissible to show respective interests of parties); Washington Lumber \& M. Co. v. McGuire, 213 Cal. 13, I P.2d 437 (I93I) (where lienholder registered certificate in his own name-prevailed over prior lienholder who allowed debtor to pass clear title); Anderson v. Commercial Credit Co., r ro Mont. 333, ror P.2d 367 (I940) (conditional buyer did not receive certificate of title-held seller's assignee liable for penalty on failure to deliver title after payment); Yarwood v. DeLage, 9I N. E.2d 272 (Ohio App. 1949) (conditional seller's rights sustained against bona fide purchaser who obtained duplicate certificate). 
all of the states prohibit this action either by penal sanction, or civil sanction invalidating the sale. ${ }^{147}$ This follows from the statutory provisions requiring assignment of the certificate upon transfer of "ownership."

In these cases where the lienholder retains possession of the certificate, or title in his name, the failure to conform to the technical requirements of the statute must further be weighed against the equities of third persons who transact business with the lienholder. Subsequent lienholders are required to perfect their liens upon the certificate of title for protection against third parties, and so good faith seemingly would require them to get the certificate before making a loan. ${ }^{148}$ Subsequent purchasers or transferees under the statutes legally are required to obtain an assignment of the certificate, under the compulsion of either penal or civil sanctions. ${ }^{149}$ Creditors, who normally rely upon the information shown by the lien records, would be compelled to demand the title certificate, if the courts were to give effect to this type of unperfected lien. ${ }^{150}$

While the case law upon the subject is inconclusive, the tendency of the decisions has been to protect the lienholder who acquires possession of the certificate or causes it to be registered in his name. ${ }^{151}$ This result can be justified upon the basis that

${ }^{247}$ States making the transfer "void" or ineffective are: California, Colorado, Florida, Idaho, Kansas, Missouri, Montana, Nebraska, Ohio, Pennsylvania, Texas, Utah. States which do not expressly impose civil sanctions, but punish non-compliance by penal laws are: Arizona, Arkansas, Delaware, District of Columbia, Illinois, Indiana, Maryland, Michigan, Nevada, New Jersey, New Mexico, North Carolina, North Dakota, Oklahoma, Oregon, South Dakota, Tennessee, Virginia, West Virginia, Wisconsin, Washington, Wyoming. See App. 2, col. I; App. 3, col. I.

${ }^{149}$ Cf. Lux v. Lockridge, 65 Idaho 639 , 150 P.2d 127 (1944) (one.who.failed to get certificate not a bona fide purchaser). However, the statutes do not generally impose penal sanctions upon lienholders who fail to comply with the statute. See note 92, supra; cf. Metropolitan Securities Co. v. Warren State Bank, II7 Ohio 69, I58 N. E. 8I (I927) (under former Ohio statute).

${ }^{100}$ See App. 2, col. I; App. 3, col. I. In some states a contract for the price cannot be enforced by a non-compliant seller. Sevier v. Roberts, 52 Cal. App.2d 403, I26 P.2d 380 (r942); American Automobile Ins. Co. v. Powers, 291 Mich. 306, 289 N. W. ryo (1939); Morgan v. Mulcahey, 298 S. W. 242 (Mo. App. 1927). But of. Wilson v. Mosko, IIo Colo. I27, I30 P.2d 927 (1942). Likewise, the purchaser has been denied relief. Vida v. Ruckle Bros. Inc., 53 A.2d 312 (N. J. I947); I9 Miss. L. J. 241 (1948). But cf. Willard H. George, Ltd. v. Barnett, 65 Cal. App.2d 828, 150 P.2d 591 (1944) (compliance by purchaser of new car not required until operation upon highway). However, the courts may rceognize equitable rights between the parties to a non-complaint sale. Ludwig v. Steger, 99 Cal. App. 234, 278 Pac. 494 (1929) (seller could replevin vehicle and recover for loss of use); Elder Chevrolet Co. v. Bailey County Motor Co., I5I S. W.2d 938 (Tex. Civ. App. 194I).

${ }_{160}$ Cf. Christian v. Boyd, 222 S. W.2d 157 (Tex. Civ. App. 1949) (lienholder retaining possession of unregistered certificate defeated by subsequent mechanic's lienholder who extended credit).

${ }^{161}$ Colonial Finance Co. v. Hunt, $290 \mathrm{Ky} .299$, I60 S. W.2d 591 (1942) (finance company holding possession of manufacturer's certificate prevailed over subsequent purchaser in course of trade); Commercial Banking Corp. v. Active Loan Co., I35 Pa. Super. 124, 4 A.2d 616 (1939) (one retaining lien under bailment lease with possession of certificate prevailed over subsequent lienholder); Associates Inv. Co. v. National City Bank of Waco, 23 I S. W.2d 66r (Tex. Civ. App. I950) (chattel mortgagee who retained possession of certificate of title given priority over subsequent purchaser in regular course of trade); Clade v. National City Bank of Waco, 229 S. W.2d 815 (Tex. Civ. App. 1950); cf. Nelson v. Fisch, 39 N. W.2d 594 (Iowa 1949); Sims v. Sugg, I65 Kan. 489, I96 P.2d I9I (1948) (purchaser who failed to get certificate of title did not prevail over owner who parted with possession on a bad check); Maryland Credit Finance Corp. v. Franklin Credit Finance Corp., I64 Va. 579, I80 S. E. 408 (1935) (lien filed with motor vehicle agency but not noted on certificate-execution creditor preferred). In Elder Chevrolet Co. v. Bailey County Motor Company, I5I S. W.2d 938 (Tex. Civ. App. I941), a sale was made by a dealer who retained a chattel mortgage and the certificate of title. The court strained to 
the certificate of title has become a type of commercial document of quasi-statutory origin, possession of which is necessary to establish full rights of ownership. Consequently, possession of the document is and should be sufficient to put buyers and lienholders upon further inquiry if they are to satisfy the requirements necessary to qualify as good faith purchasers. ${ }^{152}$ This view is recognized obliquely in Florida, Idaho, Nebraska, and Ohio, where the statutes invalidate transfers and deny estoppel against persons in possession of the certificate..$^{153}$

This result, however, may be subject to objection on the part of creditors, who ordinarily rely upon the information to be found in the public records. Where the lien does not clear through the proper motor vehicle agency, record of the lien under the lien-debtor's name is lacking. Consequently, a substantial number of cases have tended to protect creditors where the lien was not properly perfected.154 A good deal is to be said in support of the creditors, and the credit agencies, who take their information from the public records. By compelling the creditor to determine the debtor's ownership of a motor vehicle by asking for the certificate of title, an embarrassing and impractical method of credit information is substituted. But since credit information normally comes from many other reliable sources the price might not be too high to deny creditors this protection. ${ }^{165}$ In the long run, the business

resolve the equities between the seller who had violated the statute, and a subsequent purchaser who was equally as guilty. The court finally held that since the original sale was void, the seller could keep the vehicle if the money paid by the purchaser was returned. The effect of this odd decision is considcrably nullified by the two Texas decisions cited above.

Failure of a seller to deliver the certificate of title constitutes a cloud upon the title, and may give grounds for equitable relief or rescission. Pacific Finance Corp. v. Gherna, 36 Ariz. 509, 287 Pac. 304 (1930) (conditional seller justified in refusing payment where certificate outstanding); Acquisto v. Bank of America Nat. T. \& Sav. Ass'n, 213 P.2d 775 (Cal. 1950) (entruster forced to give up certificate of title when lien discharged); Buss v. McKee, 115 Colo. 159, I70 P.2d 268 (1946) (assignor of mortgagc who failed to perfect lien upon certificate forced to pay damages to assignee); Larison-Frees Chevrolet Co. v. Payne, 163 Ore. 276, 96 P.2d 1067 (1939) (conditional purchaser permitted to rescind where certificate of title not delivered within 21 days after sale); Automobile Banking Corp. v. Weicht, I60 Pa. Super. 422,51 A.2d 409 (1947) (entruster could compel trustee to give certificate of title showing entruster's limited interest only).

Many cases will be found where the lienholder has been defeated, but most of the cases concern the rights of buyers in the course of trade. E.g., Associates Discount Corp. v. Hardesty, I22 F.2d 18 (D. C. Cir. I94I); Bank of America Nat. T. \& Sav. Ass'n v. National Funding Corp., 45 Cal. App.2d 320, Ir 4 P.2d 49 (I94I); L. B. Motors, Inc. v. Prichard, 303 Ill. App. 313, 25 N. E.2d I29 (1940); Owen v. Miller, I90 Okla. 205, I22 P.2d I40 (1942).

${ }_{162} C f$. Jones v. Levis, $36 \mathrm{~N}$. W.2d 757 (Iowa 1949) (where purchaser upon investigation could have determined rights of one who sold on a bad check).

${ }^{153}$ See A'pp. 3, col. 1 .

${ }^{15}$ Wargin v. Wargin, 29 Cal.2d 843 , r8o P.2d 349 (1947) (transfer of title to mortgagce treated as a fraud on creditors since mortgagor remained in possession); In re Soss, 52 F. Supp. I23 (D. Del. 1943) (trustee in bankruptcy preferred to mortgagee in possession of certificate and powcr of attorncy); Security National Bank v. Bell, I25 N. J. L. 640, 77 A.2d 552 (Err. \& App. 194r) (lien creditor defeated prior mortgagee holding title in its name); In re McDonald Sales, Inc., 51 F. Supp. 73 (W. D. Pa. r943) (trustee in bankruptcy prevailed over finance company to whom titles assigned in blank); Christian v. Boyd, 222 S. W.2d 157 (Tex. Civ. App. x949); cf. Meskiman v. Adams, 83 Ind. App. 447 , I49 N. E. 93 (I925) (fraudulent conveyance).

${ }_{205}$ Cf. Willard H. George, Ltd. v. Barnett, 65 Cal. App.2d 828, 150 P.2d 591 (1944) (daughter's automobile titled in mother's name-held: creditors of mother could not reach property unless actual reliance upon apparent ownership); Universal Credit Co. v. Botetourt Motor Co., I80 Va. I59, 21 S. E.2d 800 (I942) (delay in perfecting security interest on title did not defeat rights of lienholder who perfected before creditors obtained lien); In re Lowry, 40 F.2d 321 (4th Cir. 1930) (certificate of title gave wrong motor. number, but valid against trustee in bankruptcy). 
of financing automobiles would gain in so far as a cheap but reliable method of imparting constructive notice would be available to the public and the lending industry.

One obstacle to the use of the title certificate without proper registration arises from the fact that the legal machinery in all the states permits an owner to replace a certificate of title by applying for a duplicate. If the lienholder's interest does not appear upon the records of the issuing motor vehicle department, it is relatively easy for the lien-debtor to obtain a duplicate, and pass the substitute instrument on to a third party. ${ }^{156}$ Here the provisions of the statutes are quite inadequate. Some of the statutes provide that the duplicate must be so marked. ${ }^{157}$ Others provide in no uncertain terms that the old certificate is "void."158 Under the former, purchasers may be put on notice that the title of one passing such a certificate is doubtful. ${ }^{159}$ Under the latter type of statute, purchasers may be justified in accepting the certificate at face value. Statutes without either provision leave much to be desired. But as a general rule, the case law has tended to protect third persons who rely upon the status of a duplicate certificate, as against the claims of prior lienholders who fail to have their interest noted upon the certificate of title and upon the records. ${ }^{160}$ The soundness of this position is evidenced by the statutes which place this risk upon the lienholder who does not properly perfect his security interest.

Under the Uniform Commercial Code. The Uniform Commercial Code in general language provides that a security interest is perfected "when registered" on the certificate of title in those states with qualifying legislation. ${ }^{101}$ This adds neither

${ }^{300}$ See App. 2, col. 8; App. 3, col. 13.

107 These states are Florida, Idaho, New Mexico, Ohio, Texas, Utah, and Washington.

158 These states are Arkansas, Indiana, Maryland, Michigan, and Tennessee.

${ }^{100}$ Some states either require the vendor to put up indemnity, or permit purchasers to require such indemnity. These states are California, Colorado, Florida, Nebraska, and Texas.

${ }^{100}$ Motor Investment Co. v. Knox City, I4I Tex. 530, I74 S. W.2d 482 (x943); General Credit Corp. v. Lee James, Inc., 8 Wash.2d I85, III P.2d 762 (I94I); cf. Shockley v. Hill, 9 I Colo. 45I, 15 P.2d 623 (1932) (title papers obtained by purchaser on bad check); Sax Motor Co. v. Mann, 7I N. D. $22 \mathrm{r}, 299 \mathrm{~N}$. W. 691 (194r) (purchaser from seller in possession who obtained duplicate title defeated because of actual knowledge of buyer's interest). Where the records of the motor vehicle agency fail to show an outstanding interest a duplicate certificate will, and should, be issued. Cf. Rigney v. Swingley, 112 Mont. IO4, II3 P.2d 344 (I94I). Where, however, a new certificate is obtained by forgery under circumstances negating apparent authority to deal with the certificate, the instrument is usually held invalid as an indicia of ownership. Ragner v. General Motors Acceptance Corp., 66 Ariz. I57, I85 P.2d 525 (1947) (foreign mortgagor obtaining clear certificate of title could not pass good title to Arizona purchaser); Winship v. Standard Finance Co., 40 Ariz. 382, I2 P.2d 282 (I932) (automobile left for repairs with dealer who forged assignment of certificate upon which a loan advanced by bank-held: for owner); Yarwood v. DeLage, 9I N. E.2d 272 (Ohio App. r949) (duplicate obtained by conditional buyer ineffective to pass title to innocent party); Adkisson v. Waitman, 213 P.2d 465 (Okla. I949) (wife forged name on blank certificate left by husband in dresser drawer-husband recovered automobile from purchaser). In Erie County United Bank v. Bogart, 75 Ohio App. 250, 6I N. E.2d 8II (I944), the court invalidated a mortgage in the hands of an assignee bank where the mortgage was given under a power of attorney executed by a fictitious purchaser. The assignor-dealer at the time of the sale was the owner of the vehicle, but the mortgage was voided upon the ground of forgery. Cf. W. P. Herbert Co. v. Powell, go Cal. App. 782, 266 Pac. 620 (1928) (transferor entrusted with possession of both vehicle and certificate assigned in blank-held: purchaser charged with notice of lack of authority to pass title because name inserted included initial which did not appear in owner's signature on blank assignment); Swartz v. White, 80 Utah 150, 13 P.2d 643 (1932) (no power to transfer certificate assigned to possessor in blank).

${ }^{101}$ U. C. C. $\$ 9-402$ (Sept. 1950). 
certainty nor uniformity to the various state provisions upon the subject. Presumably the intent was to leave the matter of time and manner for perfecting vehicle liens to the separate states without introducing changes to local procedures, the effect of which could not clearly be foreseen. Such an approach might also be defended upon the ground that by doing so the Code would have been forced to invade regulatory fields outside its general purpose. This, however, overlooks the uniform pattern of the legislation in all of the states, a pattern which lends itself to a suggested possibility of uniform legislation fixing the time and manner for perfecting liens upon the certificate of title. Rhetorically, the possibility is this: Should the Code give to the certificate of title the commercial recognition it has partially received by the courts, bankers, dealers, and the public, to the extent that presence or lack of possession of the instrument itself constitutes constructive notice of the lien? The indications are that it should.

First, the title certificate laws were established chiefly for the purpose of preventing theft. ${ }^{162}$ The public records, therefore, are sufficient for this purpose if they require transfers of "ownership" interests to clear through the policing agency. Recordation of lien interests, on the other hand, principally serves the purpose of public notice, a purpose for which the records were not designed, and which has been accomplished through the title instrument. In fact, the statutes do not impose penal sanctions for failure to have liens noted upon the title certificate, a legislative recognition that the title certificate laws serve a dual function. With the further risk that outstanding title interests appear upon the records, penal sanctions seem sufficient to insure compliance in the lien-retention sale. ${ }^{103}$ Second, possession of the instrument carries with it a recognized source of title information. The public has become accustomed to regard the instrument with commercial respect because it has an official, statutory background, and because it avoids the otherwise necessary trek to the public records. ${ }^{164}$ Third, this effect has been partially accomplished through the "good faith" provisions of the Commercial Code which by editorial comment ${ }^{105}$ impose upon dealers and possibly bankers an affirmative duty to acquire a certificate of title in so far as third persons are concerned. ${ }^{188}$ Fourth, the state legislatures have been forced, either by the dealer lobby or sound reasons to abandon the requirement that the title certificate be registered with the proper department where the instrument is acquired by dealers. As a consequence practically all of the statutes permit the dealer to re-assign the title certificate without acquiring a new one. ${ }^{107}$ This

\footnotetext{
${ }^{102}$ In general sec Lusk, Effect of Registration and Certificate of Title Acts on the Ownership of Motor Vehicles, 21 IND. Bus. Studies I (I94I).

${ }^{163}$ Lien-sellers must comply with the transfer provisions under most statutes. E.g., Sevier v. Roberts, 52 Cal. App.2d 403, I26 P.2d 380 (I942).

${ }^{284}$ Cf. Commercial Credit Corp. v. Dassenko, 43 N. W.2d 299 (N. D. 1950).

${ }^{105}$ U. C. C. $\$ 1-203$, comment 2 (Spring 1950). In general see discussion at notes 103-108 stipra.

${ }^{180}$ The Secured Transactions part of the Code also provides that subsequent lienholders will prevail over prior security interests only when the second lien is perfected. U. C. C. $\$ 9 \cdot 30 I(x)$ (b) (Sept. 1950). Consequently a subsequent lienholder will defeat a prior secured lender in possession of the certificate, only when his lien is noted upon a duplicate certificate.

${ }^{167}$ See App. 2, col. 5; App. 3, col. 9. In the states providing for manufacturer's certificates, transfers
} 
legislative policy no doubt is directed by the demands of the trade, and for the same reason the policy should be extended to retail security transactions which are a necessary adjunct to the business. Fifth, while creditors may have cause to complain on the ground that this would deny to them a public source of credit knowledge, ${ }^{108}$ their inconvenience may not be a serious one in view of the overall convenience provided to the credit industry. And finally, the danger of fraud on the part of lien-debtors who retain, under the statutes, power to apply for and receive a duplicate title certificate could be eliminated by recognizing this as one of the risks that the lienholder undertakes when the lien is not properly cleared through official channels. ${ }^{169}$ A practical solution would be to protect the lienholder so long as a duplicate certificate is not acquired by the lien-debtor or one claiming under him.

Rights of third parties. The total lack of care with which the rights of third parties have been defined by lien provisions of the various title certificate statutes has been mentioned, ${ }^{170}$ and the scant case authority upon the subject has done little to clarify the overall picture. ${ }^{171}$ It is sufficient to demonstrate the need for uniformity by two contrasting decisions from each side of the continent dealing with the rights of creditors. In Chelhar v. Acme Garage, ${ }^{172}$ a California decision preferred an execution creditor over a mortgagee who had failed to disclose his lien upon the certificate of title but had repossessed the property before execution. The Virginia court in Universal Credit Co. v. Botetourt Motor Company ${ }^{173}$ reached a conclusion directly to the contrary upon the basis that delay in perfecting a lien under the Virginia statute affected only the rights of lien creditors.

While the problem of defining the rights of third parties is, perhaps, a technical one, and a matter which for policy reasons might well vary from state to state, the lack and diversity of judicial interpretation in this field of law makes it one ripe for uniform legislation. Here the Code will serve a useful purpose in settling the rights of third parties without litigation, and this the Code does with care, and with certainty. ${ }^{174}$ Failure to file or perfect the lien is fatal only against creditors who become lien creditors without notice, but a purchase money security interest is valid against lien

from manufacturers to dealers are not generally required to clear through the central agency. E.g., Crawford Finance Co. v. Derby, 63 Ohio App. 50, 25 N. E.2d 306, 308 (1939): "The manufacturer's certificate was the key to the whole situation. As long as plaintiff held it, it knew no one could acquire a title or lien ahead of its lien. ..."

${ }^{108}$ See cases cited notes 154,155 stlpra. $\quad{ }^{108}$ See note I60 stipra.

270 The statutory provisions are set out at note 55 supra.

${ }^{172}$ E.g., Consumers Credit Co. v. Manifold, 65 Idaho 238 , I42 P.2d I50 (I943) (sheriff privileged to levy upon vehicle where unacknowledged lien filed with motor vehicle department); In re Soss, 52 F. Supp. 123 (D. Del. 1943) (trustee in bankruptcy prevailed over lienholder in possession of title certificate with power of attorney where not perfected through central agency); In re Berlin, I47 F.2d 491 (3d Cir. 1945) (perfected lien valid against creditors); In re McDonald Sales, Inc., 5I F. Supp. 73 (W. D. $\mathrm{Pa}$. I943) (trustee in bankruptcy recovered vehicles from financer who held titles but had not perfected with department).

172 I 8 Cal. App.2d 775, 6I P.2d 1232 (1936). But cf. In re Wiegand, 27 F. Supp. 725 (S. D. Cal. 1939).

${ }_{173}$ I80 Va. 159, 21 S. E.2d 800 (1942); 29 VA. L. REv. 505 (1943); Janney v. Bell, III F.2d ro3 (4th Cir. 1940).

174 U. C. C. $\$ 9-30$ I (Sept. I950). 
creditors for ten days without perfecting. Subsequent secured lenders who become such without knowledge and perfect their liens first, prevail over the unfiled lien. Buyers obtaining possession before notice cut off the rights of non-filing secured lenders, but the purchase money lienholder has ten days to file his lien against a buyer in bulk.

As applied to the motor vehicle problem under the title certificate laws, the Code presents one minor problem of policy. It normally takes a period of time between the consummation of the loan and the clearing of the lien through the central motor vehicle agency. ${ }^{175}$ The agency is often geographically located to account for the delay. While the ten day period of grace given by the Code is sufficient against creditors and bulk purchasers, there may be need to protect the secured lender in this case against subsequent buyers for a like period of time. ${ }^{176}$ Since the lienholder can acquire possession of the certificate of title at the time of the loan, there is no reason why protection should not be extended against these parties, at least for the period of grace. This, of course, could be accomplished through the simple expedient of recognizing possession of the title instrument as a form of notice, as previously suggested. ${ }^{177}$

Inventory financing. The use of the title certificate in dealer financing has led to a considerable amount of litigation, and a mass of judicial dogma which neither simplifies nor provides enlightenment of the problem. The difficulty appears to stem from several sources. Of these, probably the most important has been the general policy of the law to protect purchasers in the regular course of trade. ${ }^{178}$ This policy is at odds with a system which permits a financer to perfect his lien upon an instrument which buyers under the title laws are required to get. As a consequence, finance companies who find that a dealer has sold inventory and appropriated the proceeds are inclined to proceed against the buyer in the regular course of trade upon the theory that the lien (if it prohibited sale) is good against such purchasers if perfected upon the title certificate. The reasoning for this proceeds upon the theory that all purchasers are required to comply with the title certificate laws and therefore this includes buyers in the regular course of trade. Here the courts have strained on the one side to protect the buyer, and upon the other to rationalize the literal effect of the statutes which either impose civil sanctions or invalidate transfers contrary to the title certificate laws. ${ }^{179}$ In the great bulk of cases the buyer in the regular course

${ }^{176}$ See, e.g., Colorado State Bank v. Riede, 92 Colo. 36x, 20 P.2d ro1o (1933).

$1^{\text {T0 }}$ Where the first lienholder acquires possession of the certificate, limited protection is given against subsequent lienholders by the Code, since subsequent lienholders must perfect their security interest first. This protection is restricted by the possibility that a subsequent lienholder could take the vehicle by way of pledge, or the remote possibility that the subsequent lienholder could acquire a duplicate certificate.

${ }^{177}$ See discussion at notes $162-169$ supra.

${ }^{178}$ E.g., Fogle v. General Credit, Inc., 122 F.2d 45 (D. C. Cir. 194I).

${ }^{178}$ E.g., California Standard Finance Corp. v. Riverside Finance Co., III Cal. App. 15I, 295 Pac. 555 (193I) (where lienholder retained certificate of title and dealer sold to buyers on conditional sale, held assignee of purchaser in course of trade prevailed-assignee of purchaser on "fake sale" did not); Peper v. American Exchange National Bank, 357 Mo. 652, 210 S. W.2d 4I (I948) (prior purchaser in regular course preferred over subsequent lienholder who got certificate of title). 
of trade has won out, though often on a rather weak rationale. ${ }^{180}$ In states where the courts are disinclined to impose civil sanctions for non-compliance with the title laws imposing penal sanctions, the purchaser in regular course of trade is usually protected. This position is illustrated by Associates Discount Corporation v. Hardesty, ${ }^{181}$ where the court protected the buyer against a finance company which had retained the certificate of origin upon a new vehicle in the possession of a dealer. The argument that the buyer could not be a good faith purchaser, since he did not obtain the necessary transfer papers, was discarded on the simple ground that the law imposed other sanctions only, and therefore the prior law extending protection to purchasers in regular course of trade remained unaltered.

Serious interpretive difficulty is created by the statutes which purport to make all sales contrary to their provisions "void" or otherwise invalid. ${ }^{182}$ Literally, most of the statutes make no exemption in favor of purchasers in the regular course of trade. ${ }^{183}$ As a consequence the courts in these states have been inclined to uphold the inventory lienholder against all third parties. ${ }^{184}$ There is, however, a definite tendency to protect the buyer in regular course of trade where the lienholder is guilty of technical omissions in perfecting the lien upon the certificate and through the proper agency. ${ }^{185}$

${ }^{280}$ Fogle v. General Credit, Inc., I22 F.2d 45 (D. C. Cir. 194I); Bank of America Nat. T. \& Sav. Ass'n v. National Funding Corp., 45 Cal. App.2d 320, II4 P.2d 49 (194r); California Standard Finance Corp. v. Riverside Finance Co., Ix I Cal. App. 151, 295 Pac. 555 (193I) (decided before present California statute excluding trust receipts); Nash Miami Motors, Inc. v. Bandel, 160 Fla. 925, 37 So.2d 366 (1948); L. B. Motors, Inc. v. Prichard, 303 Ill. App. 313, 25 N.E.2d 129 (1940); Rasmussen v. O. E. Lee \& Co., 104 Mont. 278, 66 P.2d 119 (1937); Buttinghausen v. Rappeport, 13 I N. J. Eq. 252, 24 A.2d 877 (Ch. 1942); Finance Corp. of N. J. v. Jones, 97 N. J. L. I06, II6 Atl. 277 (Sup. Ct. 1922), $a f f^{\prime} d, 98$ N. J. L. I65, I19 Atl. I71 (Err. \& App. 1922); Automobile Finance Co. v. Munday, I37 Ohio St. 504, 30 N. E.2d 1002 (1940); Erie County United Bank v. Bogart, 75 Ohio App. 250, 6r N. E.2d 811 (1944); Owen v. Miller, r9o Okla. 205, 122 P.2d 140 (1942); Motor Investment Co. v. Knox City, $\mathrm{I}_{41} \mathrm{I}$ Tex. 530, ${ }_{744}$ S. W.2d 482 (I943). The buyer in regular course of trade who receives a clear certificate of tide is always protected against inventory lienholders where the lien is not perfected through the title certificate. La Porte Discount Corp. v. Bessinger, 9I Ind. App. 635, I7I N. E. 323 (r930); Sorensen v. Pagenkopf, I5I Kan. 913, Ior P.2d 928 (1940); Daas v. Contract Purchase Corp., 3 I8 Mich. 348,28 N. W.2d 226 (I947); Rasmussen v. O. E. Lee \& Co., I04 Mont. 278, 66 P.2d I 19 (1937).

${ }_{182}^{122}$ F.2d 18 (D. C. Cir. 194r). $\quad{ }^{182}$ See App. 3, col. x.

${ }^{183}$ However, the statutes in Florida, Idaho, Nebraska, Ohio, and Texas literally protect lienholders in possession of the certificate against purchasers in the course of trade although a power of sale is given. Florida Stat. ANN. \$319.22(1) (1949); Idaho Code Ann. \$49-4I5 (1949); Neb. Rev. Stat. \$60-I 1o (1943); Ohio Code ANn. \$6290-4 (I945); Tex. Stat., Penal Code art. I436-I, \$45 (1948). ${ }^{184}$ Colonial Finance Co. v. Hunt, $290 \mathrm{Ky} .299$, I6o S. W.2d 59r (I942) (applying Ohio law); Crawford Finance Co. v. Derby, 63 Ohio App. 50, 25 N. E.2d 306 (I939); Associates Inv. Co. v. National City Bank of Waco, 23r S. W.2d 66r (Tex. Civ. App. I950); Clade v. National City Bank of Waco, 229 S. W.2d 815 (Tex. Civ. App. 1950); cf. Lux v. Lockridge, 65 Idaho 639, 150 P.2d I27 (1944) (customer left vehicle with dealer to be subsequently traded in).

${ }^{186}$ E.g., San Joaquin Valley Securities Co. v. Prather, 123 Cal. App. 378, rx P.2d 45 (1932); Buttinghausen v. Rappeport, $\mathrm{I}_{3} \mathrm{r}$ N. J. Eq. 252, 24 A.2d 877 (Ch. r942) (financer kept possession of certificate contrary to statute); Automobile Finance Co. v. Munday, 137 Ohio St. 504, 30 N.E.2d 1002 (1940) (finance company obtained certificate showing lien in transferee who had never obtained proper assignment of certificate); Motor Investment Co. v. Knox City, r4I Tex. 530, I74 S. W.2d 482 (I943) (buyer in regular course protected without receiving proper certificate on ground that statute did not apply until automobile used on highway); Nicewarner v. Alston, $228 \mathrm{~S}$. W.2d 872 (Tex. Civ. App. I950) (bank loaned upon possession of manufacturer's title without having lien noted thereon held for purchaser in regular course of trade). 
Judicial inclination to protect the purchaser in regular course of trade and to discourage dealer financing through the title certificate machinery often results from statutory provisions which grant special rights to dealers, and in some cases expressly negate floor plan liens. As a consequence, the certificate of title serves no useful purpose in expressing notice of liens upon inventory in California and Missouri, where legislation verbally excludes such types of liens. ${ }^{186}$ The bulk of the states ${ }^{187}$ have no provisions requiring dealers to obtain either a certificate of origin or an original title for new vehicles. This, of course, makes the title machinery inadequate for handling inventory liens upon new vehicles. ${ }^{188}$ At least, it makes for uncertainty because third persons have no practical way of knowing whether a dealer has acquired the certificate or not. Furthermore, transferees from dealers are not required by the sanction provisions of the laws to get a certificate from the dealer, but at most are required to obtain a bill of sale or other assignment which can simply be duplicated. With respect to used automobiles, dealers are generally required to obtain an assignment of the certificate from their immediate transferors, and while the certificate may be re-assigned without clearing through the motor vehicle department, purchasers from them are compelled to get the re-assigned certificate. Therefore there may be some cause for permitting inventory liens upon such property to be shown through the title certificate. ${ }^{189}$ However, some of the statutes anticipate that the dealer may make the necessary application for the certificate of

${ }^{180}$ See App. 3, col. 7. E.g., Universal Credit Co. v. M. C. Gale, Inc., 40 Cal. App.2d 796, 105 P.2d 1003 (1940); Bank of America Nat. T. \& Sav. Ass'n v. National Funding Corp., 45 Cal. App.2d 320, II4 P.2d 49 (I94I). However, it has been held that failure on the part of a financer to get the title certificate may create an estoppel in favor of a subsequent trust reccipt holder who takes a certificate of title from the dealer. People's Finance \& Thrift Co. v. Bowman, 58 Cal. App.2d 729, 137 P.2d 729 (1943). Since the California act excludes only trust receipts, it is technically possible that other security transactions involving. motor vehicle inventory may fall within the statute. Metropolitan Fin. Corp. v. Morf, 42 Cal. App.2d 756, rog P.2d 969 (I94I). In Missouri, chattel mortgages by dealcrs, and liens incurred upon sales by distributors are not required to be noted upon the certificate of title. Butler County Finance Co. v. Miller, 225 S. W.2d 135 (Mo. App. 1949) (mortgage retained by dealer valid against subsequent purchaser from buyer in regular course of trade who obtained a clear ccrtificatc); Interstate Securities Co. v. Barton, 236 Mo. App. 325, 153 S. W.2d 393 (194I).

${ }^{187}$ See App. 3, col. 9; App. 2, col. 5 .

${ }^{188}$ First National Bank v. Emlenton Motor Co., 153 Pa. Super. 404, 34 A.2d 43 (1943) (under prior Pennsylvania statute). In most of these states the dealer is required to give his own bill of sale, with the consequent result that third persons are unable to know whether there is an outstanding bill of sale without consulting the lien records. The problem is well illustrated by Finance Corp. of N. J. v. Joncs, 97 N. J. L. 106, I16 Atl. 277 (Sup. Ct.), aff'd, 98 N. J. L. I65, I19 Atl. 171 (Err. \& App. 1922). In this casc the New Jersey statute required a dealer to give a bill of sale upon transfer. The dealer involved gave two bills of sale, one to a finance company, the other to a buyer in regular course. The buycr prevailed. Cf. Colorado State Bank v. Riede, 92 Colo. 36r, 20 P.2d 1oro (1933) (title passed when dealer gave bill of sale, and subsequent lienholder defeated).

${ }^{180}$ E.g., Metropolitan Fin. Corp. v. Morf, 42 Cal. App.2d 756, 109 P.2d 969 (194I) (wholesaler in used automobiles who sold to dealer but perfected lien upon title prevailed over subsequent lienholder); Buss v. McKee, II5 Colo. 159, 170 P.2d 268 (1946) (mortgagee who filed in county records suffered loss when dealer transferred good title to good faith buyer); Sorensen v. Pagenkopf, 151 Kan. 913, ror P.2d 928 (I940) (assignee of "fake" mortgage given by salesman to dealer defeated by subsequent purchaser who obtained clear title); Rasmussen v. O. E. Lee \& Co., 104 Mont. 278, 66 P.2d 119 (1937) (assignee of "fake" conditional sale between dealer and salesman held inferior to purchaser in regular course who received unencumbered title); Commercial Banking Corp. v. Active Loan Co. of Philadelphia, $135 \mathrm{~Pa}$. Super. 124, 4 A.2d 616 (1939) (inventory lienholder in possession of titles to used automobiles prevailed over subsequent lienholder). 
title on transfers by him, thus indicating a legislative intent to protect purchasers in the course of trade whether a certificate of title was in fact acquired or not. ${ }^{190}$ In any event the general reliance of the buying public upon the word of the dealer regarding the technical matters of registration and titling is sufficient cause for extending protection to this class of persons. ${ }^{191}$

Lenders will find that loans upon inventory must be perfected through the certificate of title in those states-Florida, Nebraska, New Jersey, Ohio, Tennessee, Texas, and Virginia ${ }^{192}$-where statutes affirmatively require compliance with the title certificate laws. As pointed out above, legislation in California and Missouri ${ }^{193}$ quite clearly requires such liens to be perfected upon other records. This leaves the effect of the statutes of the other states in serious doubt, especially as to the inventory financing of new vehicles with respect to both the place of filing and the rights of purchasers in regular course of trade. ${ }^{194}$ Thus cautious lenders in states which do not require titling of new vehicles by dealers would be wise to comply with the general filing statutes and to demand from the dealer a certificate of title upon which the lien may be perfected. Policy considerations lead one to believe that the title certificate is useless in inventory financing. The great cost of handling each title certificate adds expense to an already costly financing business, and because dealers must have the title certificate to carry on their business, surrender of the instrument by the dealer to the lienholder inevitably will slow up sales. ${ }^{195}$ The present machinery provided by the Uniform Trust Receipts Act, and that offered by the Commercial Code, furnish better and more equitable protection.

Under the Uniform Commercial Code. Any doubt in the title certificate states as to the rights of the buyer in ordinary course of business is resolved by the Code which provides that such purchaser takes "free of a security interest even though perfected and even though the buyer knows of the terms of the security agreement." ${ }^{196}$ This will do much to create uniformity, and add certainty with regard to inventory liens perfected upon the title certificate.

${ }^{100}$ In Florida, Michigan, Nebraska, and Ohio the dealer is permitted to handle the paper routine in obtaining the certificate of title for purchasers. FLA. Stat. ANN. \$3I9.23(5) (1949); Mich. Acts I950, c. 300, \$257.217(b); Neb. Rev. Stat. \$60-106 (1943); Oho Code ANN. \$6290-5 (1945).

101 "It is common knowledge that dealers frequently, if not always, take care of title transfers and registration, as well as licensing, as part of the transaction of sale, often completing these matters after receiving payment and making delivery." Rutledge, J., in Fogle v. General Credit, Inc., I22 F.2d 45 (D. C. App. 1941), 136 A. L. R. 814, 821 (I94I); Dennis v. Bank of America Nat. T. \& Sav. Ass'n, 34 Cal. App.2d 618, 94 P.2d 51, 55 (1939) (custom on part of dealers to handle paper work and application for certificate of title established by employee of motor vehicle department).

102 See App. 3, col. 7; Universal Credit Co. v. Botetourt Motor Co., I80 Va. I59, 2I S. E.2d 800 (1942). Sec cases cited note 184 supra.

103 See note 186 stipra.

104 Cf. Colorado State Bank v. Riede, 92 Colo. 361, 20 P.2d roro, rorI (I933) ("The act does not require the purchaser of a new automobile from a dealer to record his dealer's bill of sale as a condition precedent to the passing of title to him."); Finance Corp. of N. J. v. Jones, 97 N. J. L. 106, i I6 Atl. 277 (Sup. Ct.), $a f f^{\prime}$, 98 N. J. L. I65, 119 Atl. I7I (Err. \& App. I922) (dealer gave two bills of sale); Owen v. Miller, 190 Okla. 205, I22 P.2d I40 (1942).

${ }^{100}$ Cf. Smith, Marketing of Used Automobiles 192 (I94I); Hanna, The Extension of Public Recordation, 3I CoL. L. REv. 617, 632-633 (I93I).

${ }^{100}$ U. C. C. $\$ 9-307$ (Sept. 1950). 
However, the Code provision requiring liens to be perfected by registation upon the title certificate in states providing for registration of "all liens" on the certificate of title will add still further confusion, and probably make for non-intended results. This arises from the doubt existing in many states as to whether "all" types of inventory liens may be shown upon the certificate of title. ${ }^{107}$ The California and Missouri statutes are clearly excluded from this section, since the laws of those states do not provide for the registration of inventory liens in this manner. ${ }^{108}$ It seems unsound to exclude states from the operation of this section of the Code merely because inadequate provision has been made by their laws for notation of liens upon the certificate of title for another, and, probably, more important reason. The title certificate upon which liens are noted does not provide a satisfactory method for imparting notice of inventory security interests because the instrument is needed by the dealer for carrying on his business. Retention of the certificate by financers will constitute a nuisance because of the delay involved in handling each title transaction. ${ }^{199}$ Therefore it would satisfy the needs of the dealer, the financer, and third parties to permit public filing, separate and apart from the title records. Speaking generally, four classes of persons have an interest in knowing of automobile inventory liens. They are purchasers in the regular course of trade; bulk purchasers; other lienholders; and creditors. Purchasers in the regular course of trade are adequately provided for by the Code. The others, bulk purchasers, lienholders, and creditors, would find substantial protection in the public records without lien interests being shown upon the certificate of title. ${ }^{200}$ This difficulty could be eliminated simply by excluding inventory liens from the Code section requiring liens to be perfected by registration on the title. This would mean that inventory liens would be filed in the central or local records provided for in the case of other inventory liens. ${ }^{201}$ Such an arrangement would add symmetry to the Code plan of filing, so that liens covering inventory, equipment, and accounts would be perfected upon the same records.

Title certificate as a document of commerce-assignment of chattel paper. In the purchase of automobiles much of the consumer credit is handled through the process of discounting or assigning chattel paper taken by dealers in the course of retail sales. ${ }^{202}$ In this way the burden of financing retail purchasers is cast upon banks and finance companies, the dealer in this indirect fashion being relieved of the burden. Thus a dealer who, for example, sells an automobile on a conditional sale can take the papers signed by the buyer to his bank or finance company, which will in turn either purchase the paper or make a loan on its security. Consequently, the dealer not only is able to purchase more inventory, but is also able to devote a larger share of his time and capital to the buying and selling of the commodity.

${ }^{107}$ Cf. Nicewarner v. Alston, 228 S. W.2d 872 (Tex. Civ. App. 1950).

${ }^{108}$ See note 186 stupra.

${ }^{200}$ The assumption is made upon the ground that this group is made up of professional business men who normally have at their disposal information from the records furnished by credit investigation agencies.

${ }^{201}$ U. C. C. $\$ 9-401$ (Sept. 1950).

${ }^{202}$ SMith, Markettivg Used Automobiles 193 (194I). 
Such a type of wholesale financing has the additional advantage of including in one package both the sale of the automobile and the retail credit.

With the dealer occupying a position of quasi-trust, however, several serious problems may confront the assignee financing agent. The assignee must gamble on the lien's having been properly filed or recorded as well as the assignment debtor's ownership of the vehicle. Steps must be taken by the assignee to determine whether the dealer is covered by an inventory lien which includes after-acquired property. In such a transaction there is the risk of a double assignment. Also, unless the dealer is empowered to make collections, the prudent assignee will notify the account debtor in order to avoid the trouble which payments made to the dealer may cause. Finally, the assignee takes some chance that the sale is not made to a genuine retail purchaser, since the dealer can, by a "fake" sale to a fictitious person or an employee, finance his inventory at the expense of an unsuspecting bank which believes that it is receiving good retail paper. While the above risks are no doubt to be expected in such a type of financing business, they are nevertheless risks which add to the cost of the loan and must ultimately be paid by the consumer. Banks and lending institutions who normally buy or loan upon this type of paper have found that the presence of the title certificate among the other instruments or papers adds an appearance of genuineness to the transaction as well as a sense of security. It is, however, a sense which may be misleading. The chief utility of the title certificate stems from its use as a substitute form of recording or filing. In other words, the discounting bank can eliminate filing and the time-consuming search of the local records, at least in the states where liens must be shown upon the certificate of title. ${ }^{203}$

Some serious difficulty arises in cases involving double assignments. Ordinarily, this occurs where the dealer has given a prior inventory lien covering after-acquired accounts or chattel paper. Instead of accounting for the chattel paper the dealer assigns it to a second financer. In cases where the assigned obligation is not negotiable, ${ }^{204}$ a dispute may arise between the inventory lienholder and the assignee of the retail paper. Substantial case law dealing with the effect of the presence or absence of the certificate of title in this situation is not to be found, but there is some indication that the assignee bank receiving a duly perfected certificate of title with an assignment of the chattel paper will be protected. ${ }^{205}$ This conclusion is logical in

${ }^{203}$ Consequently, where the assignee does not get the title certificate, the rights of the assignee may be defeated by third parties. E.g., Superior Finance Co. v. American Security Co., I07 Ind. App. 46I, 25 N. E.2d 256 (1940) (assignee entrusted conditional buyer with clear certificate of title); General Acceptance Corp. v. Davis, I69 Kan. 220, 218 P.2d I8I (I950) (assignee failed to get certificate of title); Commercial Banking Corp. v. Active Loan Co., 135. Pa. Super. 124, 4 A.2d 616 (1939) (assignee failed to get title papers-prior lienholder prevailed). In Missouri, where the requirement that liens be noted upon the title does not apply to sales by distributing dealers, liens arising out of such transactions need not be noted upon the certificate, but must be filed in the chattel mortgage records. Butler County Finance Co. v. Miller, 225 S. W.2d I35 (Mo. App. 1949).

${ }^{204}$ Upon the general problem of the negotiability of chattel paper see Kripke, Chattel Paper as a Negotiable Specialty Under the Uniform Commercial Code, 59 YaLE L. J. I209 (I950).

206 Since the inventory lien must be entered upon the certificate of title or manufacturer's certificate, the assignee will see the lien upon the certificate if the lien has been perfected properly; if the inventory lien has not been perfected the assignee will be a good faith purchaser. Cf. Tharp v. San Joaquin Valley Securities Co., 20 Cal. App.2d 20, 66 P.2d 230 (1937). 
the states requiring inventory liens to be registered upon the title certificate. Where, however, no provision is made for perfecting inventory liens through the title instrument, as in California, the matter is left wholly to case law. Several California decisions have protected the assignee of the retail paper who receives a clear ritle certificate. $^{200}$ This result is sound because the title certificate tends to give reliability to the assignor's rights, and upon the broader principle that this type of obligation is normally transferred by an assignment of the paper which has assumed a character of limited negotiability. ${ }^{207}$ It may be that the recent legislation governing assignments of accounts receivable will have some bearing upon the problem. ${ }^{208}$ This legislation, however, is so poorly drafted that its application to secured obligations must remain wholly speculative. ${ }^{200}$

It is doubtful that the assignee who receives the certificate of title with the other

${ }^{200}$ California Standard Finance Corp. v. Riverside Finance Co., 1 I I Cal. App. 151, 295 Pac. 555 (I93I) (assignee of conditional sales contract from dealer prevailed over floor plan lienholder where dealer assigned unencumbered certificate of title); Western States Acceptance Corp. v. Bank of Italy, ro4 Cal. App. 19, 285 Pac. 340 (1930) (finance company holding a trust receipt upon a motor vehicle sold by the dealer to a second dealer and resold to a purchaser in course of trade defeated by assignec of contract); kf. People's Finance \& Thrift Co. v. Bowman, 58 Cal. App.2d 729, 137 P.2d 729 (1943). Other decisions will be found where an assignee has been given priority over a prior inventory lien, although the assignee did not acquire the certificate of title. Bank of America Nat. T. \& Sav. Ass'n v. National Funding Corp., 45 Cal. App.2d 320, Ir 4 P.2d 49 (194I); L. B. Motors, Inc. v. Prichard, 303 Ill. App. 313, 25 N. E.2d I29 (1940). But of. Universal Credit Co. v. Citizens State Bank, 224 Ind. I, 64 N. E.2d 28 (1945) (trust receipt valid against claims of subsequent assignee of conditional sale contracts). A lien upon inventory does not extend to negotiable instruments or documents transferred to a good faith purchaser, and this principle is incorporated in the Uniform Trust Receipts Act which extends the definition of such documents by including

"purchasers taking from the trustee for value, in good faith, and by transfer in the customary

manner instruments in such form as are by common practice purchased and sold as if negoti-

able. ..."

UNIFORM TRUST RECEIPTS ACr $\$ 9$.

${ }^{207}$ Cf. Uniforas Trust Receipts Act $\$ 9(\mathrm{a})$. But of. General Motors Acceptance Corp. v. Associates Discount Corp., 38 N. Y. S.2d 972 (Syracuse Munic. Ct. 1942), rev'd on other grounds, 267 App. Div. 1032, 48 N. Y. S.2d 242 (4th Dep't 1944). An excellent outline of the difficulty in giving chattel paper the aspects of negotiability is furnished by Kripke, Chattel Paper as a Negotiable Specialty Under the Uniform Commercial Code, 59 YALE L. J. I209 (1950). Mr. Kripke points out that one of the principal difficulties with the problem of giving credit value to this paper is the fact that two separate transactions are involved. One is the debt, and the other the lien or security interest. The title certificate does not solve this problem, except by giving reliability and authenticity to the security instrument.

${ }^{208}$ In general, see Koessler, New Legislation Affecting Non-Notification Financing of Accounts Receivable, 44.Mich. L. Rev. 563 (1946); Dunham, Inventory and Accotnts Financing, 62 Hakv. L. REv. 588 ( 1949 ).

${ }^{200}$ E.g., CaL. Crv. CODE $\$ 3017$ (Supp. r949) (excluding obligations represented by a "note, draft, acceptance, or other instrument for the payment of money"); IDako CoDE ANN. \$64-90I(I) (1948) (excluding obligations which are "secured by a chattel mortgage, or other instrument which may be filed in a public office"); IND. ANN. STAT. \$19-210r (Burns Replacement 1950) (excluding "mortgages and other obligations with respect to which statutory provision has been or shall be made for the record or filing of assignments"); Mich. CoMp. Laws $\$ 69 \mathrm{r} .90 \mathrm{I}(\mathrm{r})(\mathrm{a})$ (r948) (excluding any right "cvidenced by a negotiable instrument"); N. C. GEN. STAT. ANN. $\$ 44-77$ (r)(d) (Supp. 1949) (excluding "a chattel mortgage, deed of trust, conditional sale or other instrument, which is required to be recorded"); Omio GEN. CODE ANN. \$8509-5 (Supp. r949) (excluding obligations "evidenced by note, bond, bill of exchange or certificate of indebtedness of any kind"); TEx. STAT., Crviz CODE art. 260-1, \$1(1)(b) (1948) (excluding obligations "secured by a chattel mortgage, a conditional sale, contract, or other instrument which may be filed for record"); cf. Goggin v. Bank of America Nat. T. \& Sav. Ass'n, 183 F.2d 322 (9th Cir. 1950) (banker's lien). 
papers can claim negotiability in the title certificate to defeat defenses in favor of the lien-debtor against the seller-assignor. ${ }^{210}$ While the title instrument may tend to show that the assignor has an unimpeachable security interest in the vehicle, the conceptualistic common law policy of separating the debt from the security would indicate that the title laws were intended to impart notice of the lien interest only. This leads to the more difficult question of whether or not the assignment obligor must make payments to the assignee in possession of the certificate and demand that payments be noted on the title certificate. ${ }^{211}$ The legislative vacuum on the subject offers no solution. In the case of retail paper, it seems unreasonable to burden the buyer-debtor with this duty in view of the trust which normally grows out of this course of dealing. Eleven states have adopted express provisions relating to assignments and most of them contemplate that transfers of the lienholder's rights may clear through the central motor vehicle agency. ${ }^{212}$ Legislative purpose for these provisions is not expressed, and a lack of case law upon the subject ${ }^{213}$ limits further consideration of the problem. Here, however, is a demonstrated need for uniform codification.

Reliability of the title certificate as showing the rights of the assignor, and the assignment debtor, is weakened where prior possessory rights in the vehicle are claimed by third parties. Not uncommonly a dealer will sell a motor vehicle without giving up the certificate of title, with the consequence that he has in his possession an instrumentality which can be used for fraudulent purposes. If the dealer purports to resell upon a fake conditional sale, or sale with mortgage back, to one of his employees, the spurious chattel paper may be discounted to an unsuspecting financer, who perhaps is too willing to accept the presence of the title certificate as conclusive evidence of the genuineness of the transaction. Here the courts have usually protected a prior buyer or lienholder in possession, although he is without clear title

${ }^{220}$ Cf. General Acceptance Corp. v. Davis, 169 Kan. 220, 218 P.2d I8I (1950). For a case where the assignee acquired a negotiable instrument as a holder in due course, see C. I. T. Corp. v. Byrnes, 38 S. W.2d 750 (Mo. App. 193I) (debtor could not set up invalidity of sale under title certificate laws).

${ }^{211}$ If the lien secures a negotiable promissory note, the lien-debtor must obtain the promissory note upon payment; failure to record the assignment is not usually regarded as fatal. Interstate Nat. Bank v. Koster, 13I Kan. 46r, 292 Pac. 805 (1930). Where a negotiable instrument is not involved, authority upon the problem of chattel liens is very scanty. Cf. I7 GEO. L. J. 358 (I929) (criticizing rule that real estate mortgagor must look to records before making payment). The debtor may require the lienholder to surrender the certificate of title upon tender of payment. Pacific Finance Corp. v. Gherna, 36 Ariz. 509, 287 Pac. 304 (1930); Larison-Frees Chevrolet Co. v. Payne, I63 Ore. 276, 96 P.2d I067 (1939); cf. Acquisto v. Bank of America Nat. T. \& Sav. Ass'n, 213 P.2d 775 (Cal. App. I950).

Under the Code, payment by the lien-debtor to the assignor of chattel paper is privileged where the assignor is left in possession of paper which does not specify a different place of payment. U. C. C. $\$ 9.319$ (Sept. 1950). Quaere: Whether the account debtor may safely pay the assignor without demanding the chattel paper?

${ }^{212}$ See App. 3, col. II. None of the states with "incomplete" certificate of title laws have such provisions. Cf. App. 2.

${ }_{213}$ In General Credit Corp. v. Lee James, Inc., 8 Wash.2d 185, xII P.2d 762 (194I), the assignee, $F$, held a certificate of title showing a lien in favor of the assignor, $D$. Subsequently $D$ repossessed the vehicle, and on repossession sale sold to $P$ for whom $D$ obtained a duplicate certificate. Held for $P$ on the ground that the assignment was not entered upon the mortgage records where the lien had also been filed. 
papers. ${ }^{214}$ Judges occasionally have been tempted to sympathize with the assignee bank in such situations on grounds of estoppel, but the scant judicial authority in point has wholly failed to penetrate the real problem. The common law always - recognized possession of both real and personal property as imparting constructive notice of equities retained by the party in possession. ${ }^{215}$ Difficulty with the title certificate laws arises from their all inclusive language purporting to require "liens and encumbrances" to be shown upon the title..$^{210}$ It is reasonable to suppose that the omission of possessory interests was a legislative oversight which in fact recognized a common law principle so well established as to be unworthy of specific exclusion. Therefore, the constructive notice of liens upon the title certificate should be qualified by the common law principles protecting prior pledge or other possessory interests. Consequently, the assignee bank must either trust in the honesty of the assignor, or determine for itself the possessory claims of third parties.

One further hazard which has not been removed by the assignment of a duly perfected certificate of title occurs when a dealer, otherwise unable to get inventory credit, purports to sell to a salesman or a member of his staff upon a lien-retaining contract. This lien contract may then be discounted to either a suspecting or an unsuspecting financial institution which is willing to advance credit on the basis of the added security. For all substantial purposes, this leaves the dealer in possession with an apparent power of sale. Consequently, in those states which favor the buyer in regular course of trade, the courts have shown an inclination to protect the buyer, ${ }^{217}$ especially where the buyer obtains an unencumbered title certificate. ${ }^{218}$ This places

${ }^{214}$ Dennis v. Bank of America Nat. T. \& Sav. Ass'n, 34 Cal. App.2d 618, 94 P.2d 5I (1939); San Joaquin Valley Sec. Co. v. Prather, 123 Cal. App. 378, ir P.2d 45 (1932); Peper v. American Exchange Nat. Bank, 257 Mo. 652, 210 S. W.2d 4I (1948); of. Janney v. Bell, III F.2d 103 (4th Cir. 1940) (lienholder who obtained possession prevailed over creditors where lien was not perfected upon title certificate); Henry v. General Forming, Ltd., 33 Cal.2d 233, 200 P.2d 785 (1948) (possession of vehicle defeated rights of asserted owner out of possession); Colorado State Bank v. Riede, 92 Colo. 36r, 20 P.2d roro (x933) (purchaser in possession of new automobile who received only bill of sale prevailed over subsequent lien given by dealer); Universal Credit Co. v. Botetourt Motor Co., 180 Va. 159, 21 S. E.2d 800 (1942) (inventory lienholder without certificate of title who acquired possession preferred over subsequent lien creditors). But of. Chelhar v. Acme Gararge, 18 Cal. App.2d 775, 6I P.2d 1232 (1936) (mortgagee who repossessed and purchased on foreclosure sale defeated by subsequent lien creditors); Associates Inv. Co. v. Le Boutillier, 69 Ohio App. 62, 42 N. E.2d 10I I (194I) (dealer sold to buyer who obtained vehicle without manufactures's certificate-held subsequent inventory lienholder prevailed). In Rasmussen v. O. E. Lee \& Co., I04 Mont. 278, 66 P.2d I19 (1937), an automobile was sold by a dealer to a fake purchaser, and this contract assigned to $F$. Thereafter the automobilc was sold to $B$ in regular course of trade who obtained a title certificate in his name. Subsequently, $B$ traded in the vehicle and assigned the title to the dealer in blank. The dealer then turned the vchicle over to $F$. Held for $B$ on the theory that the re-transfer to $F$ did not technically comply with the title certificate statute.

${ }^{210}$ This of course is the basis of Twyne's Case, 3 Co. Rep. 80 b, 76 Eng. Rep. 809 (K. B. 160r). Consequently in order to qualify as a good faith purchaser, one must always examine the possessory rights in the property. 3 GLenN, Mortgages $\$ \$ 387-389$ (r943).

${ }^{210}$ States which expressly exclude possessory interests or pledges are Arizona, Arkansas, Colorado, District of Columbia, Pennsylvania, Tennessee, and Utah. See App. 3, col. 7.

${ }^{217}$ Cf. Automobile Finance Co. v. Munday, $\times 37$ Ohio St. 504, 30 N. E.2d 1002 (1940) (decided on grounds that fake purchaser did not technically get title); Erie County United Bank v. Bogart, 75 Ohio App. 250, 6I N. E.2d $8 \mathrm{II}$ (I944) (decided on ground that fake purchaser was wholly fictitious).

${ }^{218}$ Buss v. McKee, II5 Colo. 159, I70 P.2d 268 (1946); Guaranty Discount Corp. v. Bowers, 94 Ind. App. 373 , 158 N. E. $23 x$ (I93 I) (assignee bank had no actual knowledge that automobile displayed 
a burden upon the discounting bank to determine the identity of the lien-debtors on assigned paper, at least in the states where purchasers in the regular course of trade will be protected. However, the rule discourages an evil practice upon the part of lenders to advance inventory credit under this type of arrangement, at least where the practice is well established or known.

Under the Uniform Commercial Code. The title certificate may create several obscure, but not insolvable, problems under the "chattel paper" provisions of the Commercial Code. ${ }^{210}$ In substance the Code recognizes that liens on chattel paper may be perfected in one of two ways: First, by possession of the paper; ${ }^{220}$ second, by filing. ${ }^{221}$ However, a purchaser of chattel paper created by the sale of inventory will prevail over an earlier filed security interest when possession of the paper is acquired in the ordinary course of his business and without knowledge of the earlier lien. ${ }^{222}$ In this case the title certificate may be decisive of the question of "knowledge."223 Thus suppose that $F_{I}$ takes a lien upon $D$ 's after-acquired or existing chattel paper secured by liens on motor vehicles and this is duly perfected by filing. Subsequently, $D$ assigns the chattel paper covered by the first lien to $F_{2}$, who has no actual knowledge of the first security interest. (Where should $F_{I}$ have filed his lien? By registration on the certificate of title? Presumably the Code anticipates that filing will be governed by the general filing provisions, and not the motor vehicle section. ${ }^{224}$ ) Suppose, then, that this lien is filed in the general records, and $F_{2}$ acquires among the papers received a certificate of title showing a lien in favor of $D$ ? Or suppose that the chattel paper is unaccompanied by a title certificate? Or suppose that it is, but the title certificate shows that the lien has been assigned to $F_{I}$ ?

In these cases the Code literally purports to protect $F_{2}$, except where the accompanying title certificate shows an assignment to $F_{I}$ because "a notation on the chattel paper that it has been assigned. is sufficient" ${ }^{225}$ to constitute knowledge.

for sale); Sorensen v. Pagenkopf, I5I Kan. 913, ror P.2d 928 (I940) (assignee bank had no actual notice that automobile displayed for sale-court imposed duty to determine character of loan because of custom on part of dealers to finance inventory in this manner); Rasmussen v. O. E. Lee \& Co., Inc., Io4 Mont. 278, 66 P.2d I19 (1937) (demonstrator sold on fake sale); People's Finance \& Thrift Co. v. Shirk, I8I Okla. 4 18, 74 P.2d 379 (1937). In states which do not require inventory liens to be noted upon the certificate, a prior inventory lien will prevail over the assignee under a fake sale upon the theory that the lien is taken out of the regular course of trade. California Standard Fin. Corp. v. Riverside Fin. Co., II Cal. App. 151, 295 Pac. 555 (1931); cf. Universal Credit Co. v. M. C. Gale, Inc., 40 Cal. App.2d 796, 105 P.2d 1003 (I940) (lien upon vehicle titled in name of dealer's president valid against creditors).

${ }^{210}$ U. C. C. $\$ \$ 9-304,9-305,9-308$ (Sept. 1950).

220 U. C. C. $\$ 9-305$ (Sept. 1950).

221 U. C. C. $\$ 9-304$ (Sept. 1950).

${ }^{222}$ U. C. C. $\$ 9-308$ (I) (b) (Sept. 1950). In other cases the subsequent assignee obtaining possession is defeated by the prior perfected lien. Id. $\$ 9-308(\mathrm{I})(\mathrm{a})$.

223 "Knowledge that a security interest exists in inventory or that a security interest is claimed in the proceeds of the inventory is not sufficient to give knowledge that a security interest exists in the chattel paper in possession of the debtor, but a notation on the chattel paper that it has been assigned is sufficient." U. C. C. $\$ 9-308(2)$ (Sept. I950) .

${ }^{224}$ Note that the Code provides for the filing of liens upon chattel paper under the general filing provision. U. C. C. $\$ 9-40$ I (Sept. 1950). However, inventory liens upon motor vehicles are registered upon the certificate of title, with consequent dilemma as to whether this includes after-acquired property. This quandary could be solved by excluding inventory liens from the motor vehicle provision.

${ }^{226}$ See note 223 stupra. 
However, the "good faith" section ${ }^{226}$ of the Code may apply to require assignees of chattel paper secured by security interests in motor vehicles to get the certificate of title. Since comment to that section requires "professionals" to acquire a title certificate, there is some likelihood that assignee bankers and finance companies are included within the intent of the section. ${ }^{227}$ The uncertainty here could be eliminated by requiring the assignee of motor vehicle chattel paper to acquire the necessary title certificate, and this could be done by defining chattel paper ${ }^{228}$ to include the title certificate.

Some further difficulty arises from the Code provision permitting liens to be registered upon the certificate of title. ${ }^{220}$ This section applies only to those states where provision is made for registration of "all liens" upon the title certificate. Literally, the provision tends to exclude most title certificate states since the statutes and decisions are quite decisive in holding that possessory liens need not be entered upon the title certificate. ${ }^{230}$ In addition, this section further provides that a security interest in motor vehicles is perfected by registration upon the certificate of title, thus by implication excluding the possibility of perfecting liens by possession of the vehicle. Neither of these constructions, however, is reasonable since the section falls within the chapter on filing, thus indicating that other methods for perfecting liens are left to the other parts of the Code. ${ }^{231}$ These technical difficulties could easily be avoided by making the Code provision applicable to non-possessory liens only, and by forthright language including all states with title certificate laws.

IV

\section{Conclusion}

The uniform pattern of the legislation in all the states with "incomplete" and "comprehensive" certificate of title laws lends itself to incorporation within the security provisions of the Code as a means for imparting constructive notice of liens upon motor vehicles. Technical differences between the many separate laws may result in numerous unpredictable exclusions as a direct result of the Code language including only states providing for the registration of "all" liens. The Code requirement that a security interest will be perfected only when the lien is registered upon the title certificate by the central motor vehicle agency will perpetuate the growing litigation in cases where the lienholder retains possession of the certificate without formal registration. Inadequacy of the title certificate for showing inventory liens makes for further difficulty.

The reader is invited to give cautious consideration to a recommendation that Section 9-402 be amended by a provision to read:

${ }^{228}$ U. C. C. $\$ \mathrm{I}-203$, comment 2 (Spring 1950 ). $\quad{ }^{227}$ Discussed at notes 103-108 supra.

228 " 'Chattel paper' means a writing of a type whose transfer in ordinary course of business requires delivery and which evidences a security interest in or lease of goods." U. C. C. \$9-105(r)(b) (Scpt. I950).

${ }^{228}$ U. C. C. $\$ 9-402$ (Sept. 1950$)$.

231 U. C. C. $\$ 9-305$ (Sept. 1950).

${ }^{230}$ See note 214 stipra. 
In all states with certificate of title laws a non-possessory security interest in motor vehicles other than on inventory is perfected when

(I) properly registered upon the certificate of title, or

(2) possession of the certificate of title is retained or acquired by the secured lender. A security interest perfected by possession of the certificate ceases to be perfected at the time when the debtor or one claiming under him obtains a clear duplicate certificate of title.

This suggested amendment would:

(I) Include all of the states with certificate of title laws.

(2) Provide protection to the lienholder in possession of the vehicle.

(3) Require inventory liens and liens on chattel paper to be filed or perfected under the other provisions of the Code.

(4) Recognize possession of the title certificate by the secured lender as imparting constructive notice of liens.

This should do much to solve the mystery surrounding the certificate of title. 
APPENDIX I

States with Registration Laws

\begin{tabular}{|c|c|c|c|c|c|c|c|}
\hline & ALABAMA & CONNECTICUT & \multicolumn{2}{|c|}{ GEORGIA } & \multicolumn{2}{|l|}{ IOWA } & KENTUCKY \\
\hline $\begin{array}{l}\text { 1. Mtgors and cond'l buyers } \\
\text { required to register }\end{array}$ & \begin{tabular}{l}
\multicolumn{1}{|c|}{ Yes } \\
Ala. Code Ann. \\
tit. 36, \& $1(0)$ \\
$(1940)$ \\
\end{tabular} & $\begin{array}{c}\text { Yes } \\
\text { Conn. Gen. Stat. } \\
\delta 2350(29)(1949)\end{array}$ & \multicolumn{2}{|c|}{$\begin{array}{c}\text { Yes } \\
\text { Ga. Code Ann. } \\
\$ 68-101 \text { (1937) }\end{array}$} & \multicolumn{2}{|c|}{\begin{tabular}{|c|} 
Yes \\
Yowa Code \\
$\$ 321.1(35)(1940)$
\end{tabular}} & $\begin{array}{c}\text { Yes } \\
\text { Ky. Rov. Stat. } \\
8180.10(0)(1048)\end{array}$ \\
\hline $\begin{array}{l}\text { 2. Transferor required to notify } \\
\text { or return certificate to central } \\
\text { department by penal law }\end{array}$ & \begin{tabular}{|c|} 
Yeg \\
Id. tit. 51, \\
$\S$ 706 (Supp. 1945)
\end{tabular} & Id. $\$$ Yes 2364,2361 & \multicolumn{2}{|c|}{ No provision } & \multicolumn{2}{|l|}{ Id. \& $\underset{321.45}{\text { Yes }}$} & $\begin{array}{c}\text { No } \\
\text { Id. } 8180.100(3)\end{array}$ \\
\hline $\begin{array}{l}\text { 3. Transferor required to } \\
\text { assign certificate }\end{array}$ & No provision & No provision & \multicolumn{2}{|c|}{$\begin{array}{l}\text { Yes } \\
\text { Id. } 8 \& 68-207 \\
68-9908\end{array}$} & \multicolumn{2}{|c|}{$\begin{array}{l}\text { Yes } \\
\text { (both transferor-ce } \\
\text { required to sign } \\
\text { certificate) } \\
\text { Id. } \$ 8321.45, .40\end{array}$} & $\begin{array}{l}\text { Yca } \\
I d .88 \text { 186.100 } \\
(3-4), .000\end{array}$ \\
\hline 4. Provisions for liens & No provision & No provision & \multicolumn{2}{|c|}{\begin{tabular}{l}
\multicolumn{1}{c}{ Yes } \\
(on the assign- \\
ment by trans- \\
feror-lien inst. \\
not filed) \\
Id. 8 68-207 \\
\end{tabular}} & \multicolumn{2}{|c|}{ No provision } & No provigion \\
\hline 5. Records and inderes & $\begin{array}{l}\text { Mechanics not } \\
\text { clear } \\
C f . \text { Id. tit. } 51 \text {, } \\
\& 705(1940)\end{array}$ & $\begin{array}{l}\text { Yes } \\
\text { (by Comm'r of } \\
\text { MI. V.) } \\
\text { Id. } 8352\end{array}$ & \multicolumn{2}{|c|}{$\begin{array}{l}\text { Yes } \\
\text { (Revenue Comm'r } \\
\text { records alphabeti- } \\
\text { cally by countics) } \\
\text { Id. } 868-10 .\end{array}$} & \multicolumn{2}{|c|}{$\begin{array}{l}\text { Yes } \\
\text { (in counties and } \\
\text { Dept. of } \mathrm{M} . \mathrm{V} . \text { ) } \\
\text { Id. } \$ 8 \text { 321.21, .31 }\end{array}$} & $\begin{array}{l}\text { Yes } \\
\text { (by Dopt. of } \\
\text { leovenuo) } \\
\text { Id. } 180.240(2)\end{array}$ \\
\hline \multirow[t]{2}{*}{$\begin{array}{l}\text { 6. Certificate required to be } \\
\text { carried on vehicle }\end{array}$} & No provision & $\begin{array}{r}\text { Yes } \\
I d .82362 \\
\end{array}$ & \multicolumn{2}{|c|}{ No provision } & \multicolumn{2}{|c|}{\begin{tabular}{|c|} 
Yes \\
Id. 88 321.32, .33 \\
\end{tabular}} & No provision \\
\hline & MAINE & CHASSA- & \multicolumn{2}{|c|}{ MINNESOTA } & \multicolumn{2}{|c|}{ MISSISSIPPI } & HAMESHIRE \\
\hline $\begin{array}{l}\text { 1. Mtgors and cond'l buyers } \\
\text { required to register }\end{array}$ & $\begin{array}{l}\text { Yes } \\
\text { Me. Rev. Stat. } \\
\text { c. 19, \& } 1 \text { (1944) }\end{array}$ & No provision & \multicolumn{2}{|c|}{\begin{tabular}{l}
\multicolumn{1}{c}{ Yes } \\
Minn. Stat. \\
$8168.011(5)$ \\
$(1949)$ \\
\end{tabular}} & \multicolumn{2}{|c|}{$\begin{array}{l}\text { Yes } \\
\text { Miss. Code. Ann. } \\
\text { 6 9352-02 (1048 } \\
\text { Supp.) } \\
\end{array}$} & $\begin{array}{l}\text { Yes } \\
\text { N. H. Roy, Laws } \\
\text { c. 115, \& } 1 \text { (xx) } \\
\text { (1042) }\end{array}$ \\
\hline $\begin{array}{l}\text { 2. Transferor required to notify } \\
\text { or return certificate to central } \\
\text { department by penal law }\end{array}$ & No provision & $\begin{array}{l}\text { Yes } \\
\text { Mass. Gen. Laws } \\
\text { c. } 90, \$ 82,20 \\
(1946) \\
\end{array}$ & \multicolumn{2}{|c|}{$\begin{array}{l}\text { Yes } \\
\text { Id. } 88168.15 \\
.10(4)\end{array}$} & \multicolumn{2}{|c|}{$\begin{array}{l}\text { No provision } \\
\text { (Transtorce must } \\
\text { present tax receipt) } \\
\text { Id. } \$ 03 \mathbf{u}^{2}-10 \\
\end{array}$} & Id. $0.110, \& 13$ \\
\hline $\begin{array}{l}\text { 3. Transferor required to } \\
\text { assign certificate }\end{array}$ & No provision & No provision & \multicolumn{2}{|c|}{\begin{tabular}{l}
\multicolumn{1}{c|}{ Yes } \\
(transferee to sign \\
\& join in returning \\
to Registrar) \\
Ibid. \\
\end{tabular}} & \multicolumn{2}{|c|}{$\begin{array}{l}\text { Seller required to } \\
\text { executts "bill of } \\
\text { sale." } \\
\text { Id. } 8065-67 \\
(1942)\end{array}$} & No provision \\
\hline 4. Provisions for liens & No provision & No provision & \multicolumn{2}{|c|}{ No provision } & \multicolumn{2}{|l|}{ No provision } & No provigion \\
\hline 5. Records and indexes & $\begin{array}{l}\text { Yes } \\
\text { (by Sec'y of } \\
\text { State) } \\
\text { Id. c. } 19, \$ 13\end{array}$ & $\begin{array}{l}\text { Yes } \\
\text { (by Registrar of } \\
\text { II. V.) } \\
\text { Id. c. } 90, \& 2\end{array}$ & $\begin{array}{l}\text { (by Res } \\
\text { I. V.) } \\
\text { Id. } 16\end{array}$ & $\begin{array}{l}\text { Yes } \\
\text { gistrar of } \\
\\
8.33(3)\end{array}$ & $\begin{array}{l}\text { Bill of sale may } \\
\text { recorded with } \\
\text { Clerk of Count } \\
\text { Court } \\
\text { Id. } \$ 8066 \\
\end{array}$ & & $\begin{array}{l}\text { Yea } \\
\text { (by Comm'r of } \\
\text { M. V.) } \\
\text { Id. c. 116, } \mathbf{2} 2\end{array}$ \\
\hline \multirow[t]{2}{*}{$\begin{array}{l}\text { 6. Certificate required to be } \\
\text { carried on vehicle }\end{array}$} & No provision & $I d$. c. $90, \S 11$ & No $p$ & rovision & $\begin{array}{l}\text { Bill of sale mu } \\
\text { be exhibitcd } \\
\text { upon velicilo } \\
\text { Id. } 88007 \\
\end{array}$ & & No provision \\
\hline & NEW YORI & \multicolumn{2}{|c|}{ RHODE ISLAND } & \multicolumn{2}{|c|}{ SOUTH CAROLINA* } & & VERMONT \\
\hline $\begin{array}{l}\text { 1. Mtgors and cond'l buyers } \\
\text { required to register }\end{array}$ & $\begin{array}{l}\text { Yes } \\
\text { N. Y. Vehicle \& } \\
\text { Traffic Law } \$ 2 \\
\text { (18) (1941) } \\
\end{array}$ & \multicolumn{2}{|c|}{$\begin{array}{l}\text { Yes } \\
\text { R. I. Gen. Laws } \\
\text { c } 86,81(16) \\
(1938) \\
\end{array}$} & \multicolumn{2}{|c|}{$\begin{array}{l}\text { Yes } \\
\text { S. C. Codo Ann. } \\
\$ 1623(1)(u)(1042) \\
\end{array}$} & \multicolumn{2}{|c|}{$\begin{array}{c}\mathrm{Yes} \\
\text { Vt. Stat. }{ }_{10,044} \\
(x x)(1047)\end{array}$} \\
\hline $\begin{array}{l}\text { 2. Transferor required to notify } \\
\text { or return certificate to central } \\
\text { department by penal law }\end{array}$ & No provision & \multicolumn{2}{|l|}{ 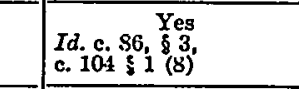 } & \multicolumn{2}{|c|}{ Id. $\$ 0904^{\text {Yes }}$} & Id. & $\begin{array}{r}\mathrm{Yeg} \\
128,075\end{array}$ \\
\hline $\begin{array}{l}\text { 3. Transferor required to } \\
\text { assign certificate }\end{array}$ & No provision & \multicolumn{2}{|c|}{ No provision } & No $\mathrm{p}$ & provision & & No proviaion \\
\hline 1. Provisions for liens & No provision & No provisi & sion & $\begin{array}{l}\text { (Applicatio } \\
\text { tration to } \\
\text { lien inst. } \\
\text { Id. \& } 5894 \\
\text { (Supp. } 194 \\
\end{array}$ & $\begin{array}{l}\text { Yes } \\
\text { iont for regis- } \\
\text { show liens- } \\
\text { nnt filed) } \\
\text { 4(17) } \\
\text { (48) }\end{array}$ & & No provision \\
\hline 5. Records and indexes & $\begin{array}{l}\text { Yes } \\
\text { (by Bureau of M. V.) } \\
\text { Id. } \$ 11 \text { (2) }\end{array}$ & Id. c. $86, \frac{\text { Yes }}{82}$ & & $\begin{array}{l}\text { (by State } \\
\text { Dept.) } \\
\text { Id. \& } 5893 \\
\end{array}$ & $\begin{array}{l}\text { Yes } \\
\text { Highway } \\
3(1942) \\
\end{array}$ & by I & $\begin{array}{l}\text { Yes } \\
\text { Dept. of M. V.) } \\
810,017\end{array}$ \\
\hline $\begin{array}{l}\text { Certificate required to be } \\
\text { arried on vehicle }\end{array}$ & Id. $\$ 11(4)$ Yes & Id. c. 86,82 & & No pr & provision & Id. 8 & $\frac{\mathrm{Ycs}}{810,074}$ \\
\hline
\end{tabular}

* These statutes have since been drastically amended. S. C. Acts 1949, No. 223. 
The Case of the Mysterious Accessory

\begin{tabular}{|c|c|c|c|c|c|c|c|c|c|}
\hline 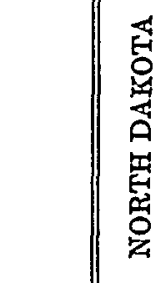 & 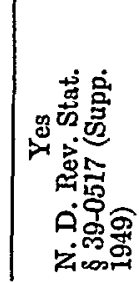 & 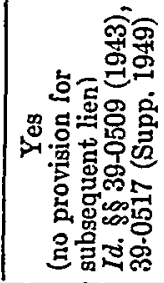 & 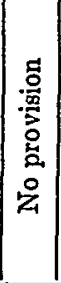 & 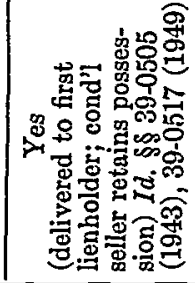 & 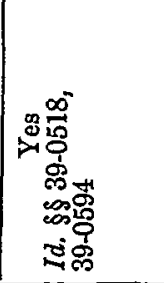 & 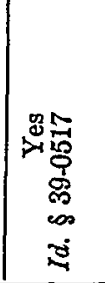 & 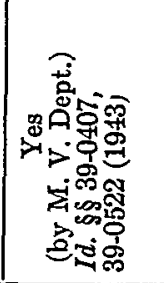 & 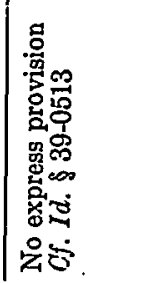 & 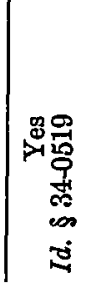 \\
\hline 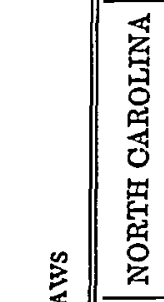 & 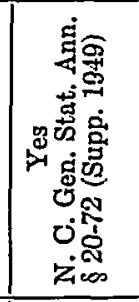 & 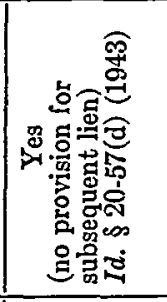 & 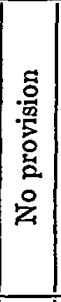 & 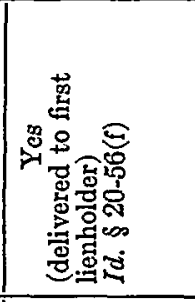 & 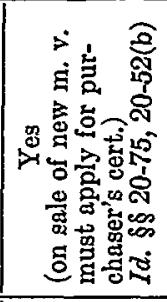 & 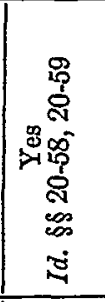 & 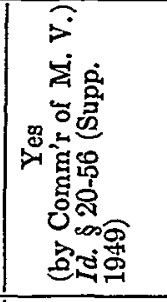 & 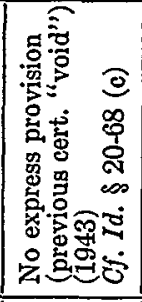 & 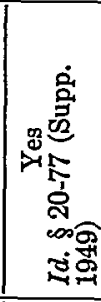 \\
\hline 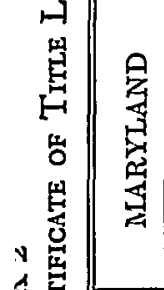 & 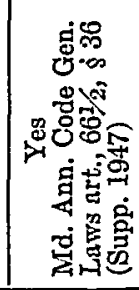 & 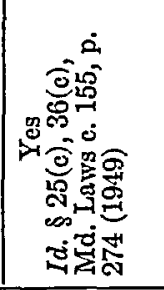 & 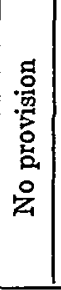 & 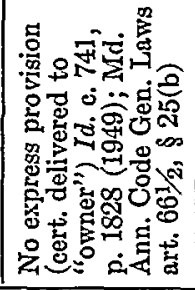 & 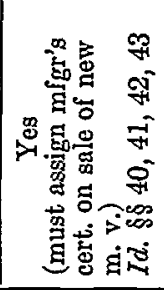 & 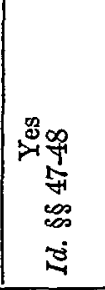 & 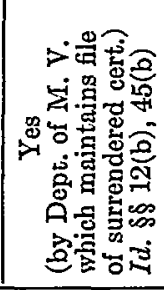 & 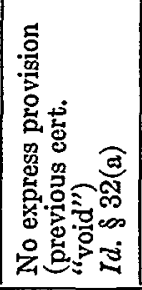 & 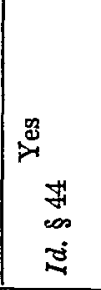 \\
\hline 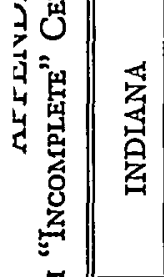 & 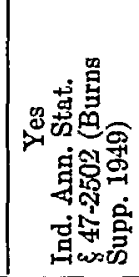 & 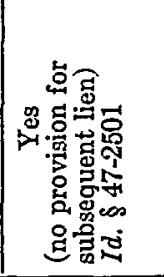 & 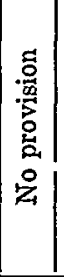 & 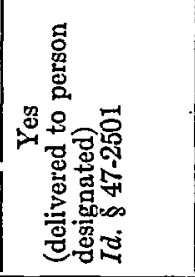 & 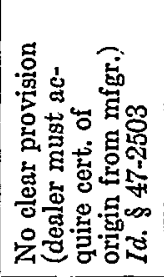 & 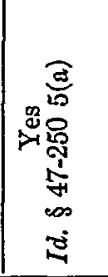 & 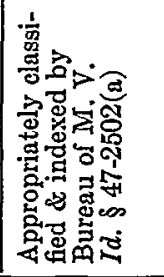 & 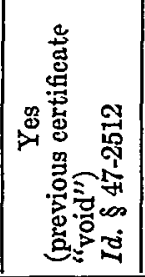 & 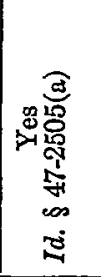 \\
\hline 总 & 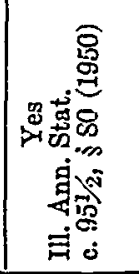 & 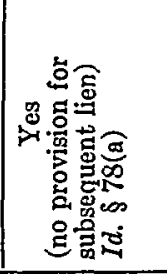 & 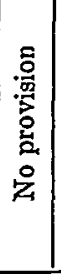 & 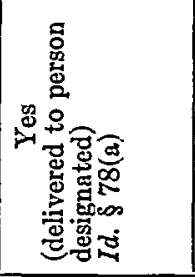 & 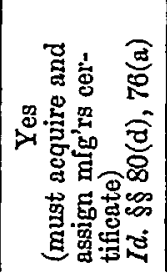 & 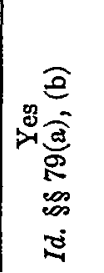 & 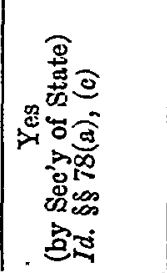 & 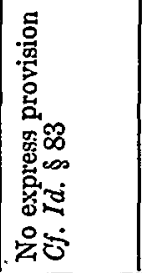 & 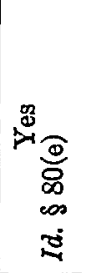 \\
\hline & 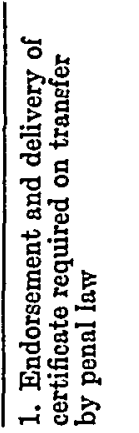 & 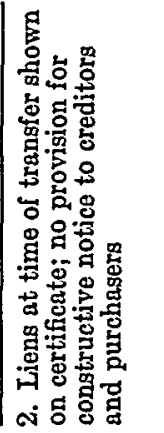 & 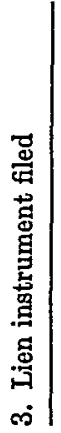 & 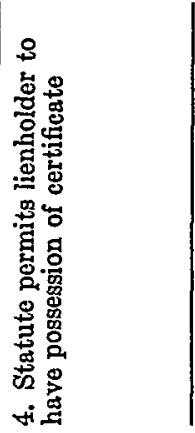 & 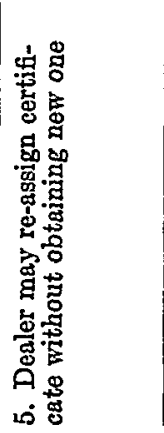 & 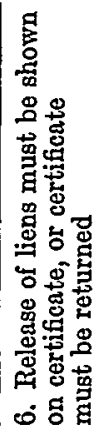 & 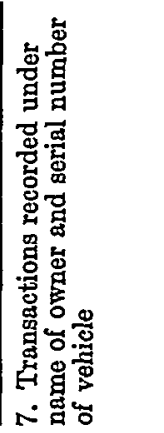 & 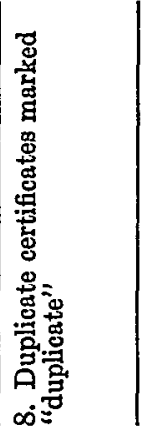 & 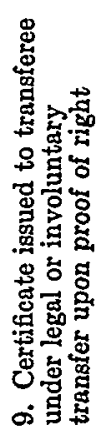 \\
\hline
\end{tabular}




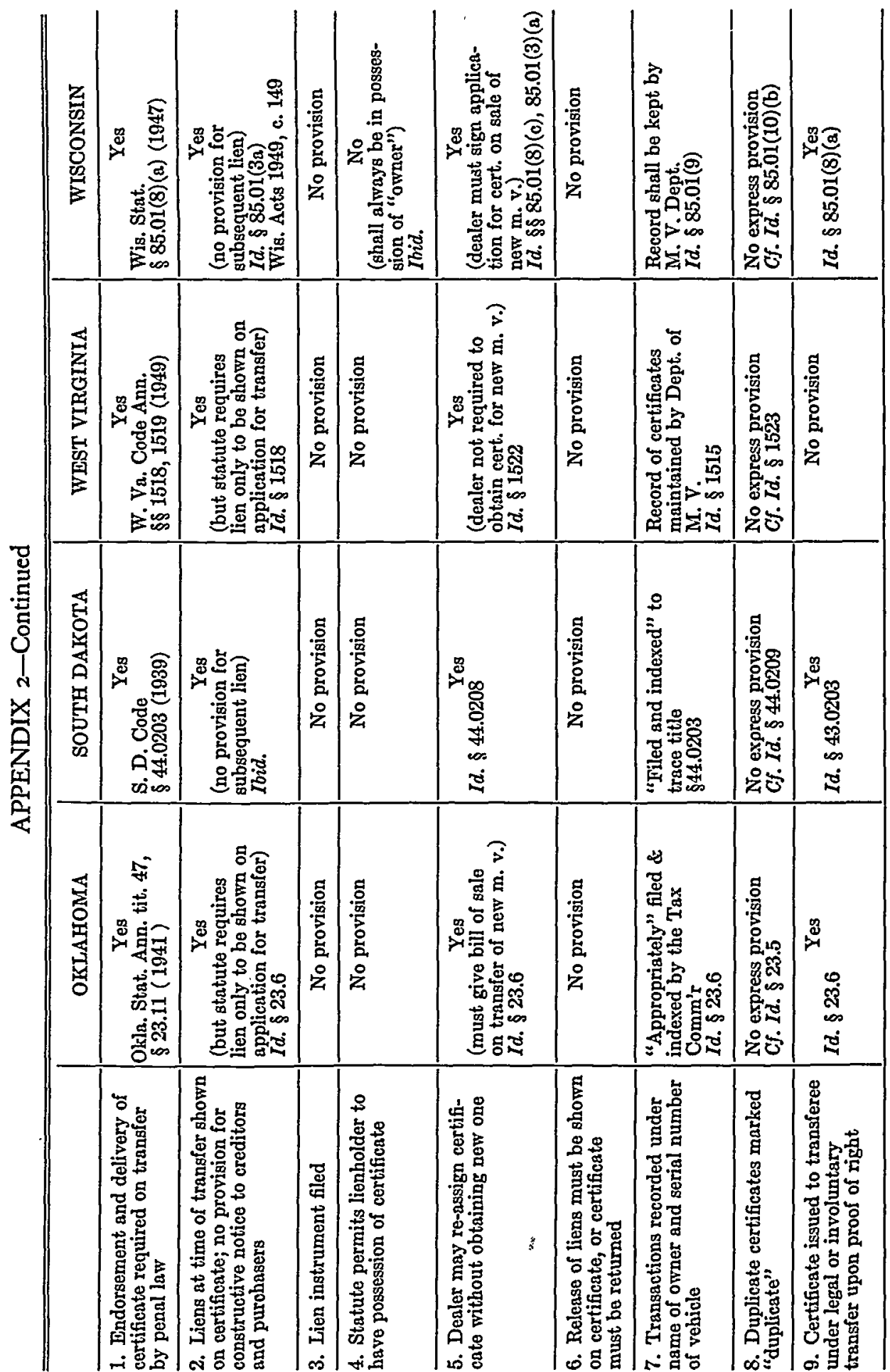


The Case of the Mysterious Accessory

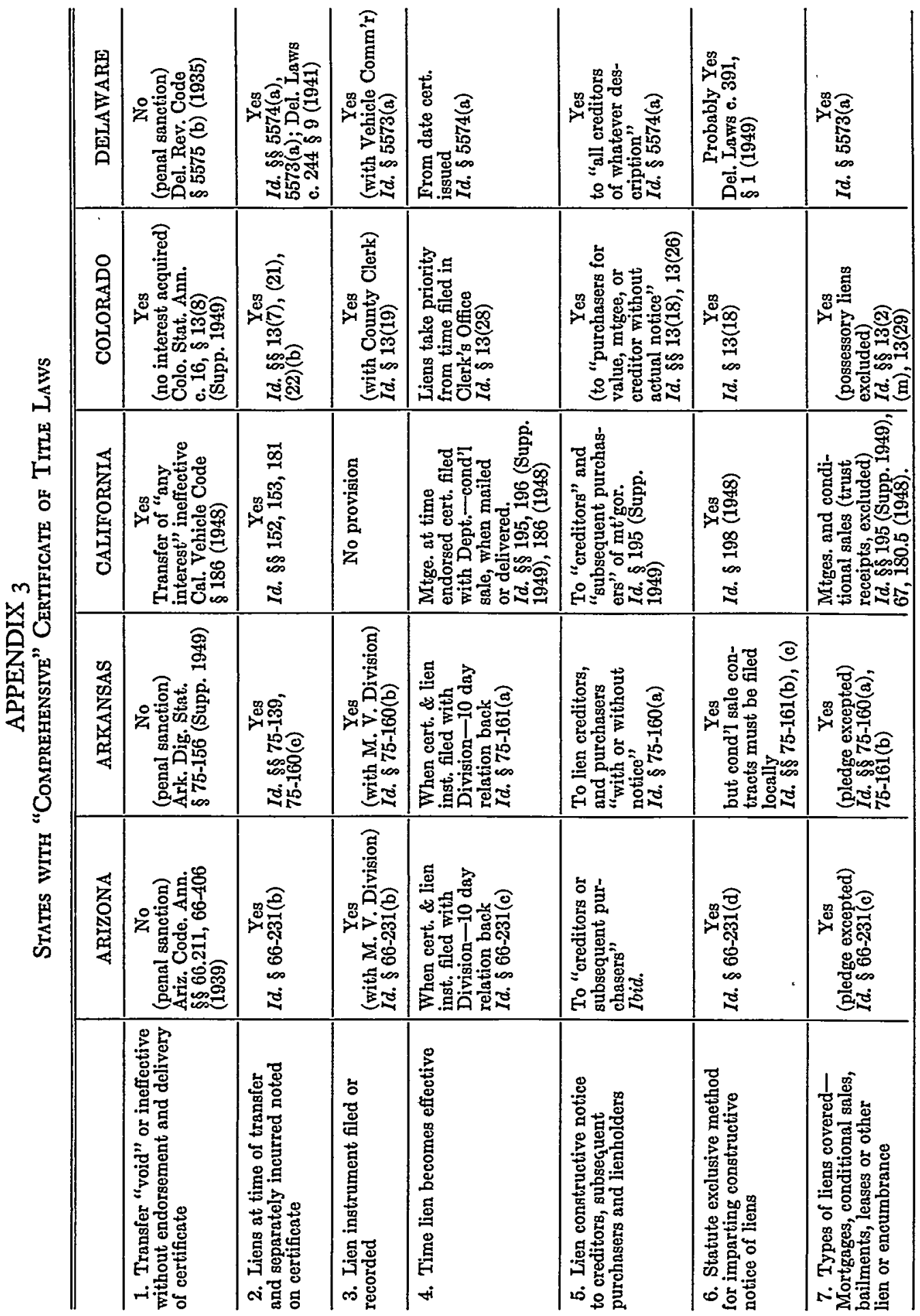




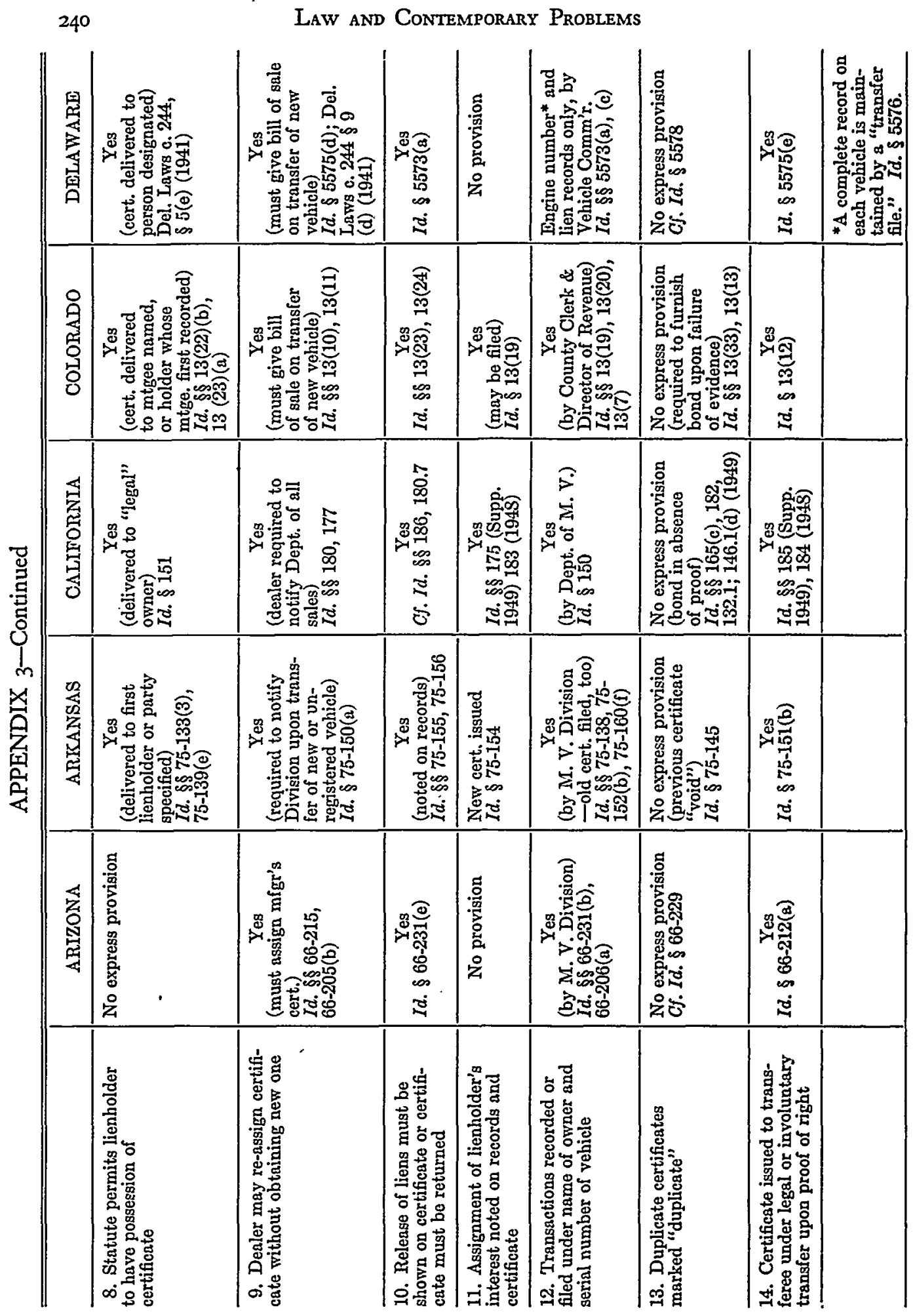


The Case of the Mysterious Accessory

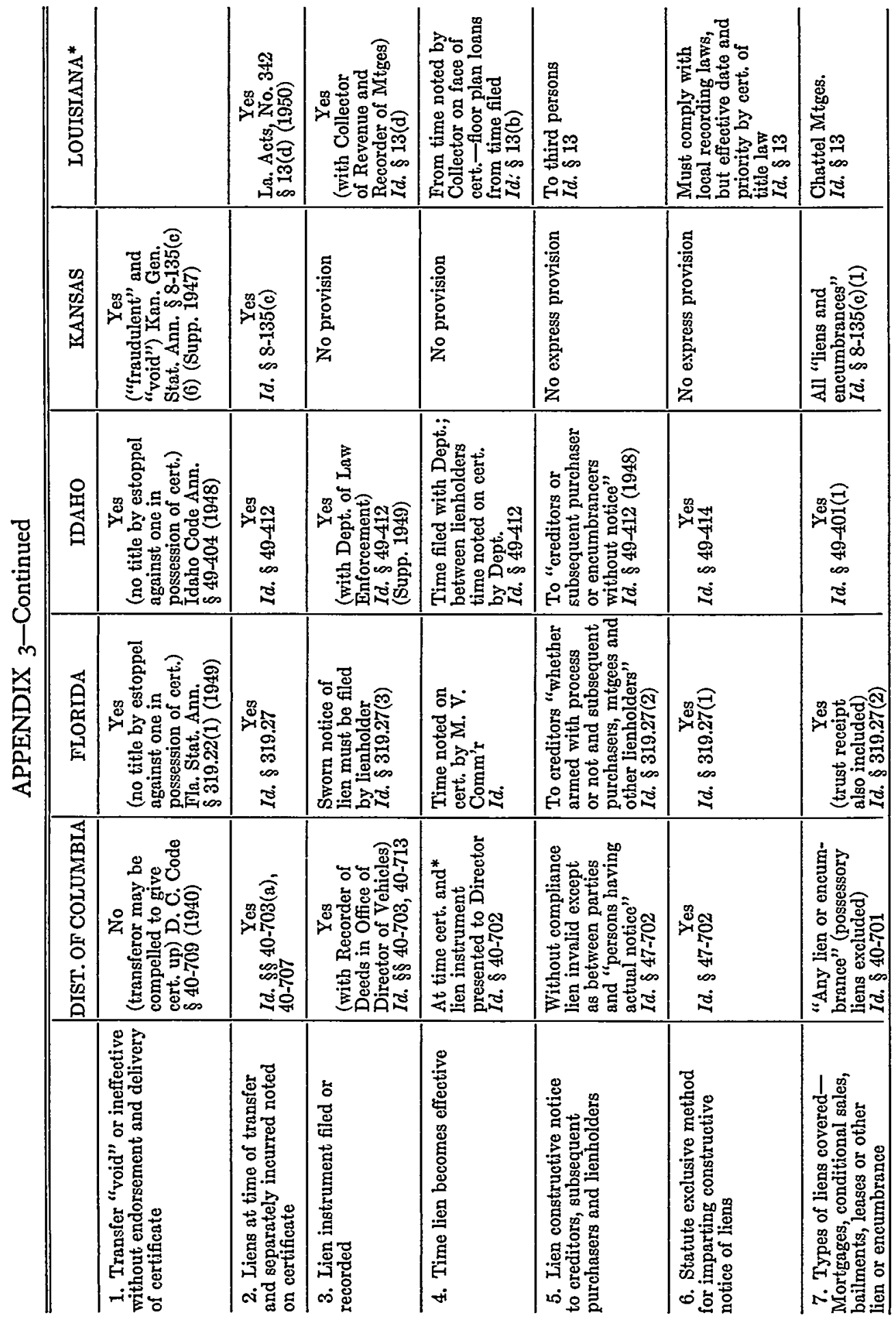




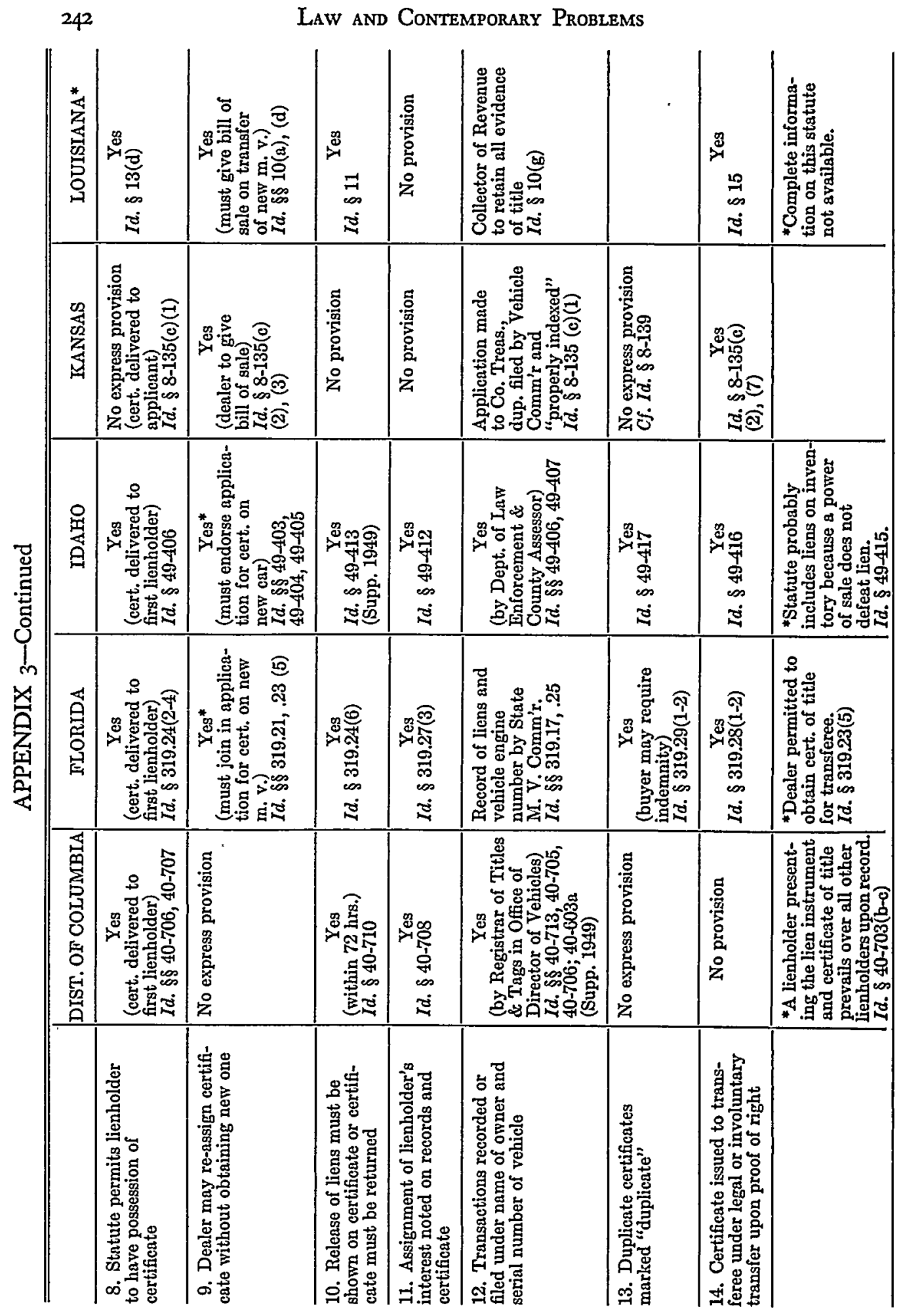


The Case of the Mysterious Accessory

\begin{tabular}{|c|c|c|c|c|c|c|c|}
\hline 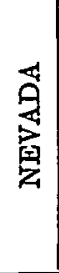 & 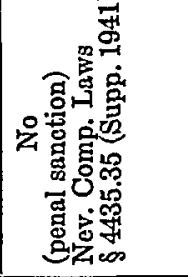 & 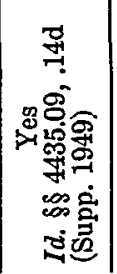 & 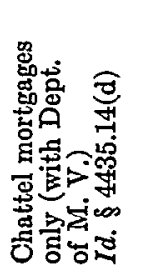 & 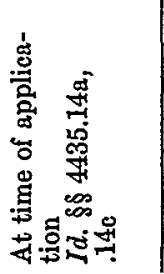 & 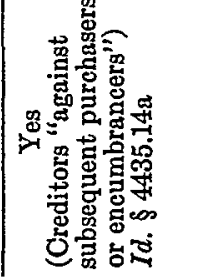 & 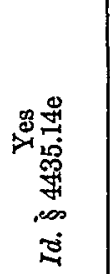 & 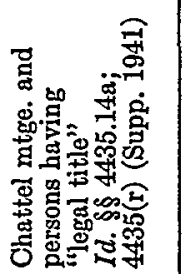 \\
\hline 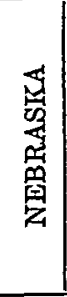 & 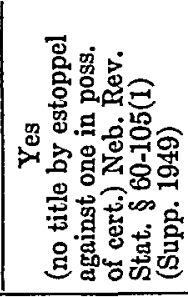 & 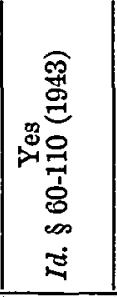 & 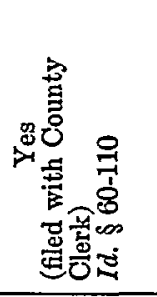 & 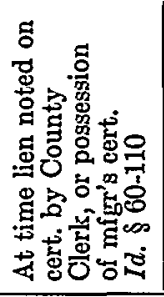 & 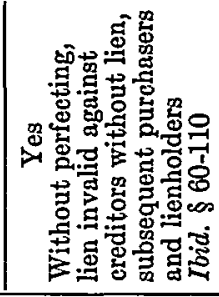 & 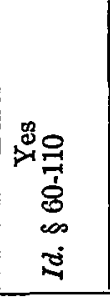 & 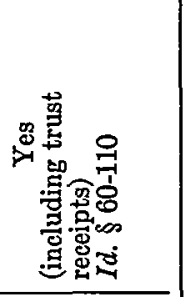 \\
\hline 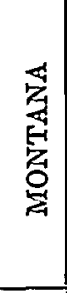 & 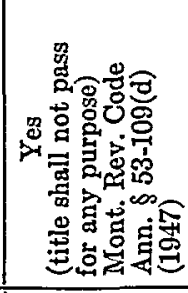 & 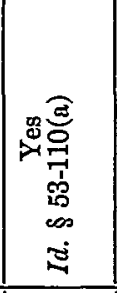 & 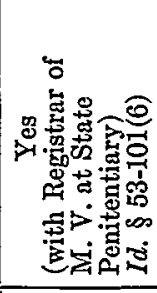 & 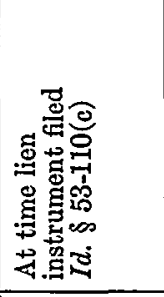 & 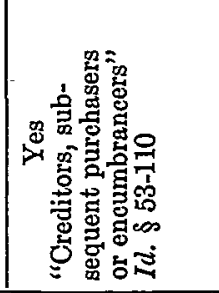 & 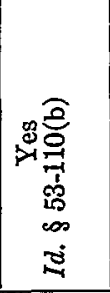 & 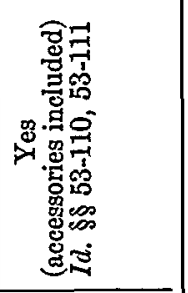 \\
\hline 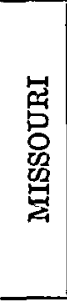 & 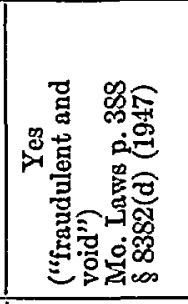 & 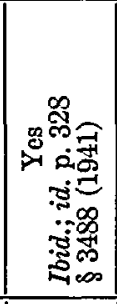 & 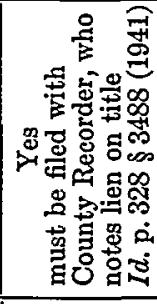 & 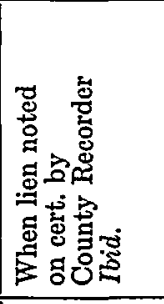 & 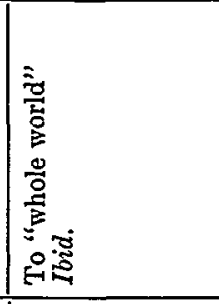 & 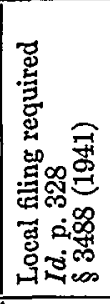 & 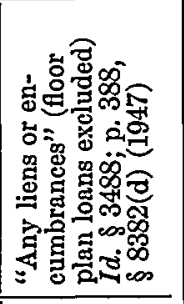 \\
\hline 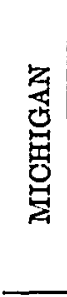 & 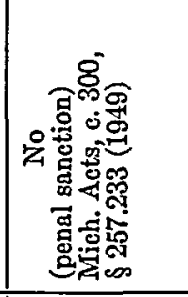 & 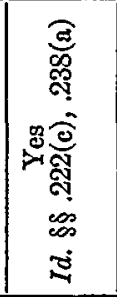 & 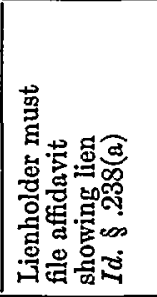 & 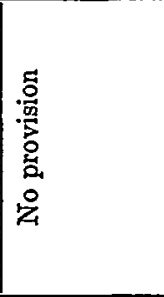 & 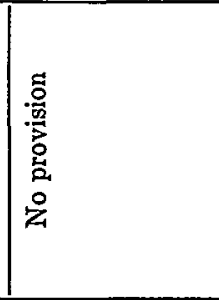 & 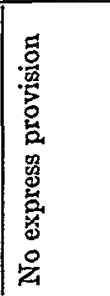 & 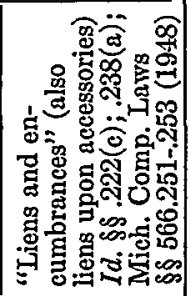 \\
\hline & 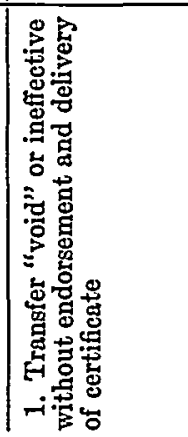 & 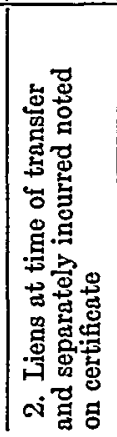 & 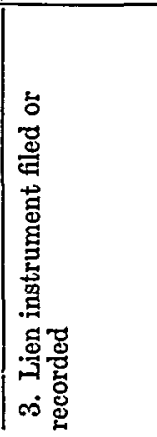 & 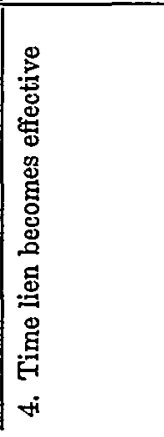 & 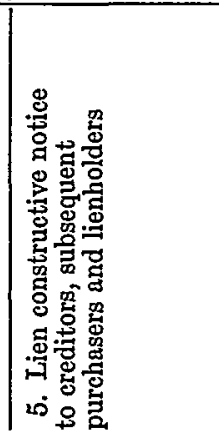 & 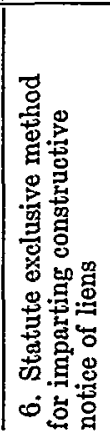 & 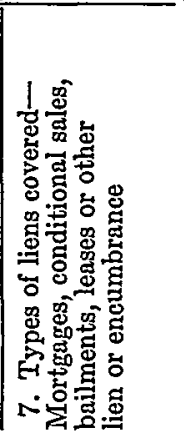 \\
\hline
\end{tabular}




\begin{tabular}{|c|c|c|c|c|c|c|c|c|}
\hline 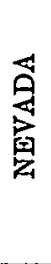 & 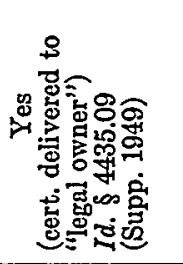 & 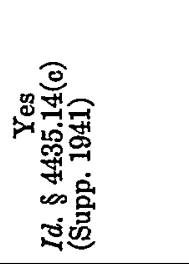 & 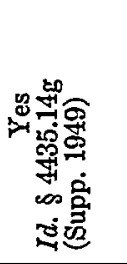 & 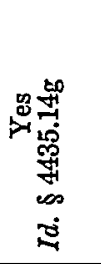 & 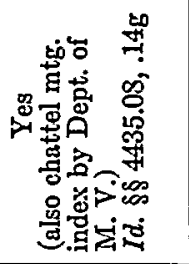 & 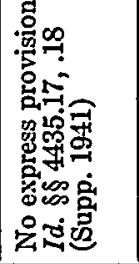 & 兽 & \\
\hline 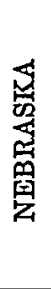 & 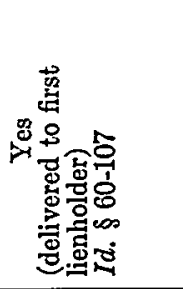 & 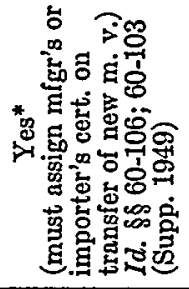 & 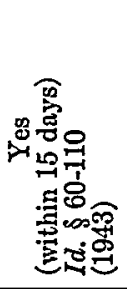 & $\begin{array}{l}\text { 总 } \\
\text { 总 } \\
\text { 总 } \\
\text { 号 }\end{array}$ & 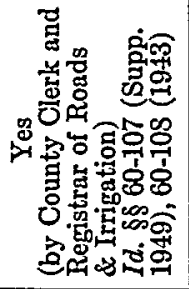 & 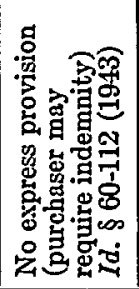 & 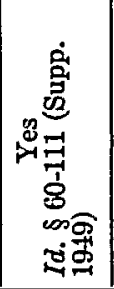 & 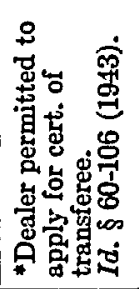 \\
\hline 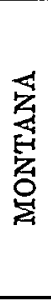 & 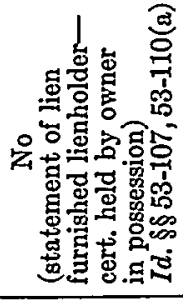 & 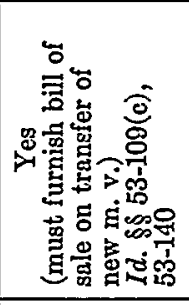 & 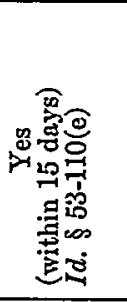 & 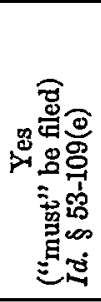 & 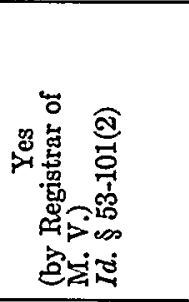 & 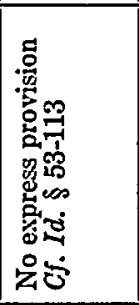 & 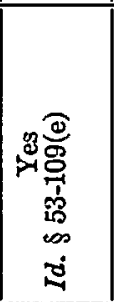 & \\
\hline 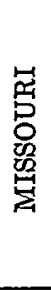 & 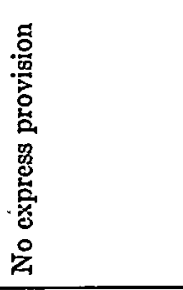 & 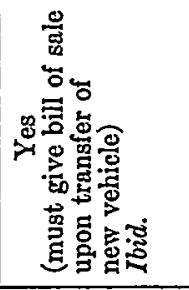 & 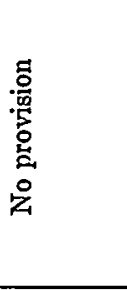 & 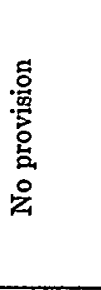 & 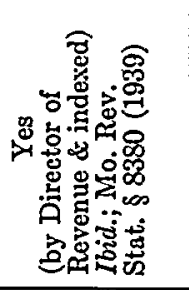 & 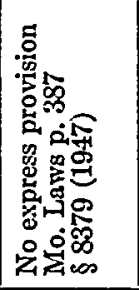 & 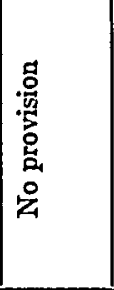 & \\
\hline 总 & 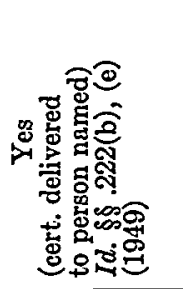 & 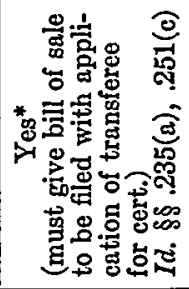 & 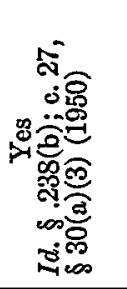 & 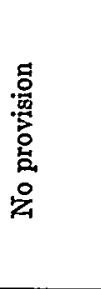 & 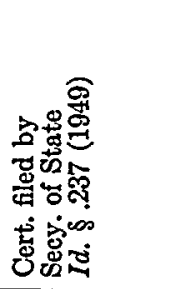 & 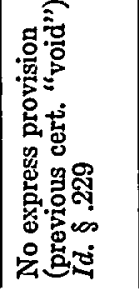 & 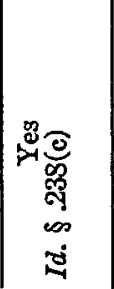 & 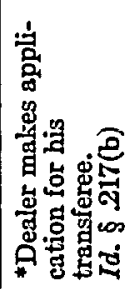 \\
\hline & 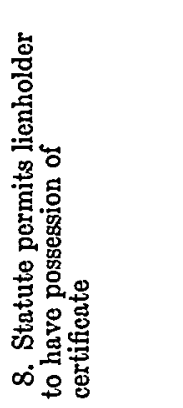 & 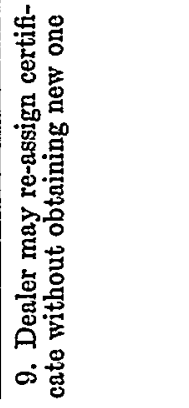 & 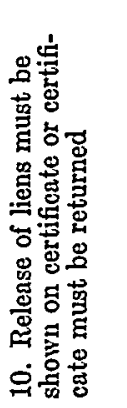 & 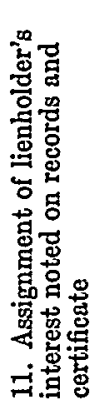 & 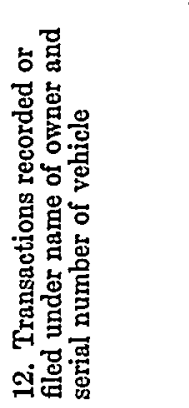 & 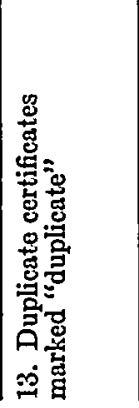 & 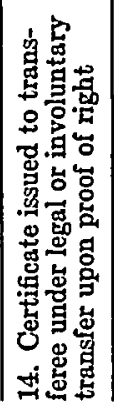 & \\
\hline
\end{tabular}


The Case of the Mystertous Accessory

\begin{tabular}{|c|c|c|c|c|c|c|c|}
\hline 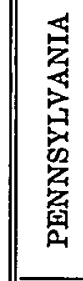 & 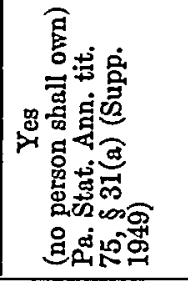 & 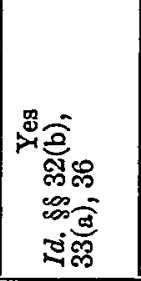 & 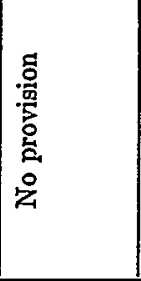 & 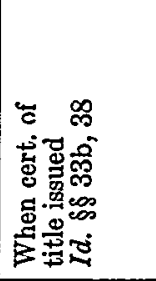 & 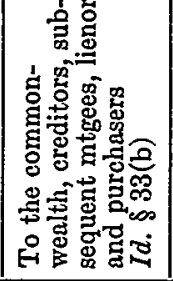 & 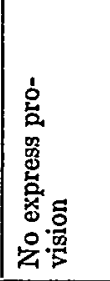 & 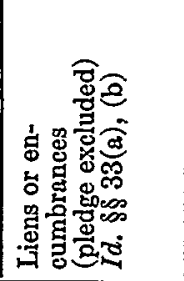 \\
\hline 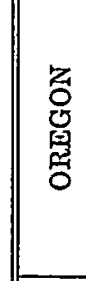 & 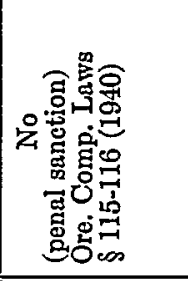 & 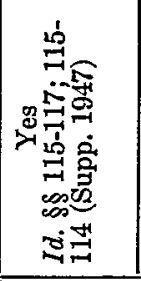 & 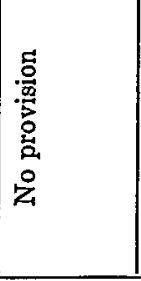 & 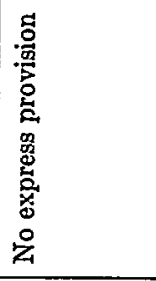 & 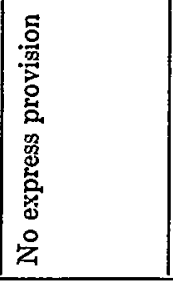 & 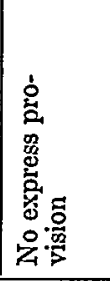 & 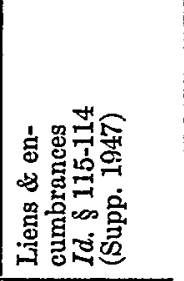 \\
\hline 是 & 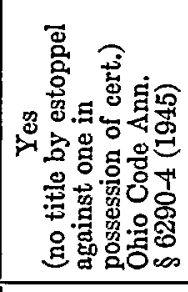 & 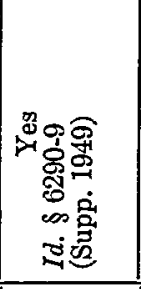 & 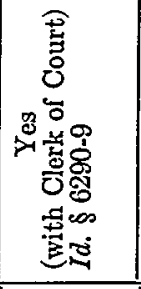 & 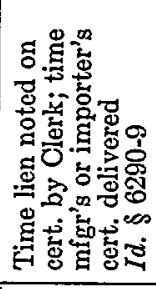 & 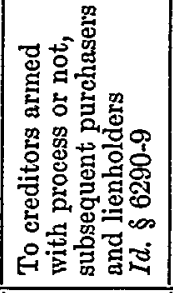 & 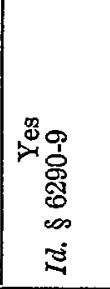 & 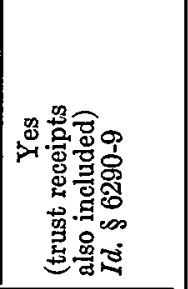 \\
\hline 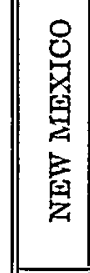 & 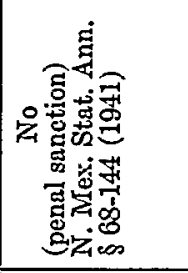 & 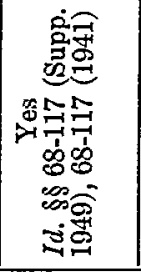 & 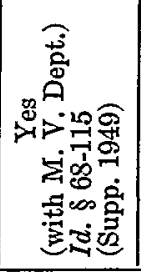 & 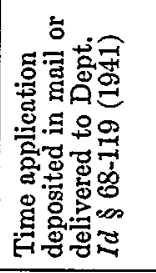 & 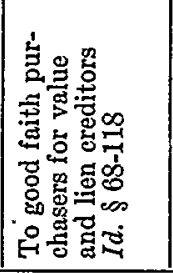 & 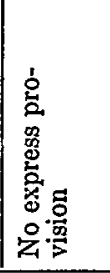 & 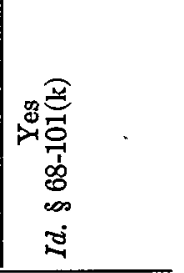 \\
\hline 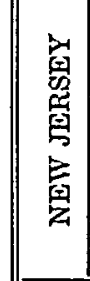 & 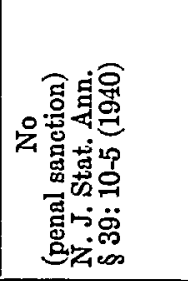 & 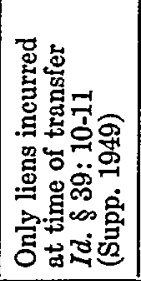 & 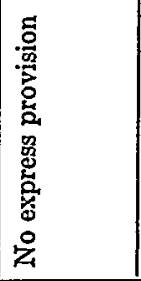 & 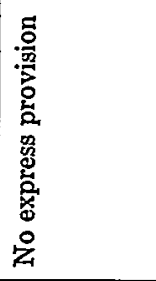 & 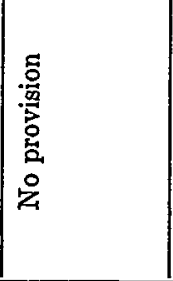 & 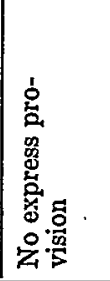 & 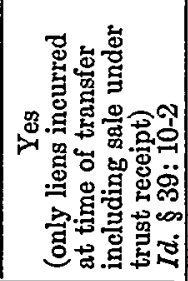 \\
\hline & 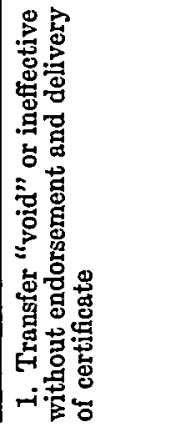 & 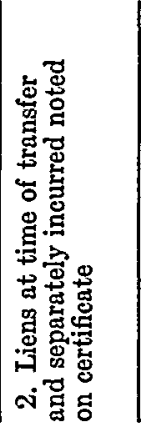 & 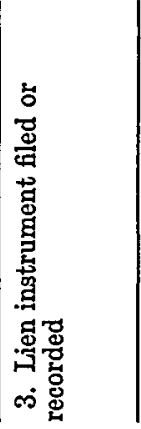 & 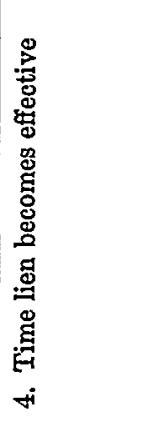 & 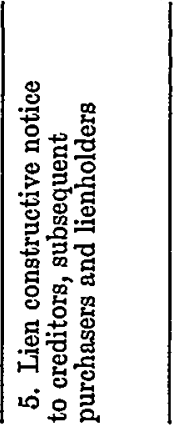 & 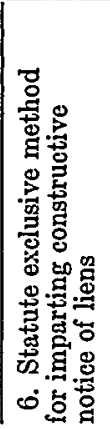 & 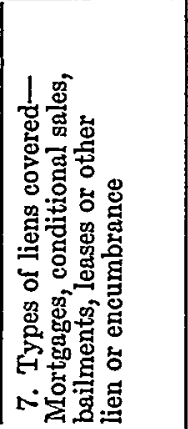 \\
\hline
\end{tabular}




\begin{tabular}{|c|c|c|c|c|c|c|c|c|}
\hline 246 & \multicolumn{8}{|c|}{ LaW and Contemporary Problems } \\
\hline 弯 & 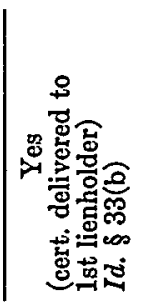 & 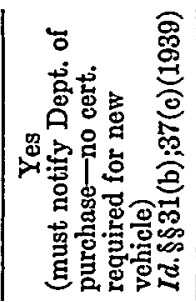 & 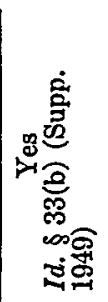 & 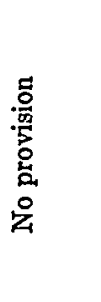 & 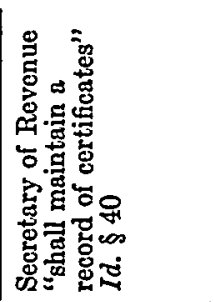 & 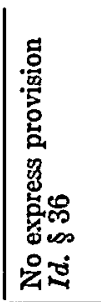 & 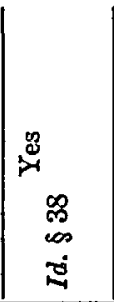 & \\
\hline 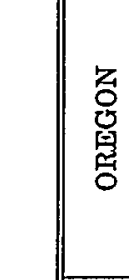 & 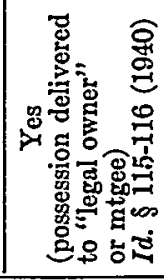 & 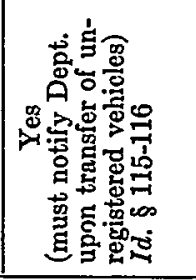 & 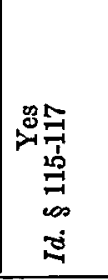 & 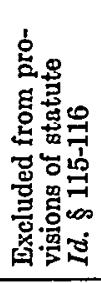 & 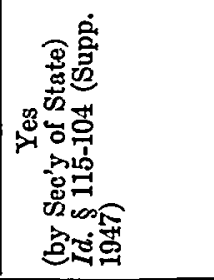 & 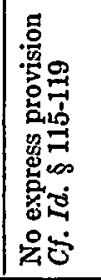 & 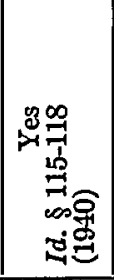 & \\
\hline 总 & 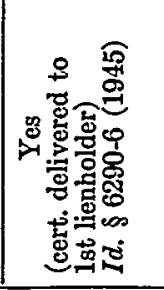 & 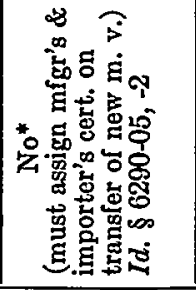 & 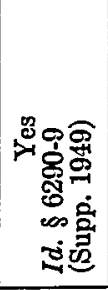 & 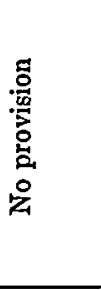 & 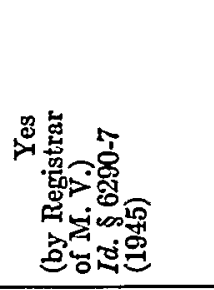 & 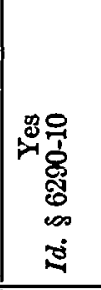 & 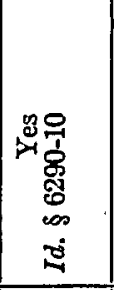 & 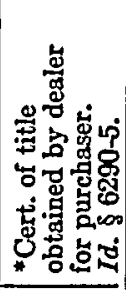 \\
\hline $\begin{array}{l}\text { O } \\
\text { 离 } \\
\text { 鼠 } \\
\text { 鼠 }\end{array}$ & 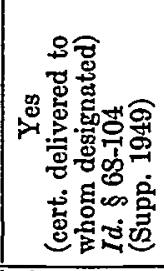 & 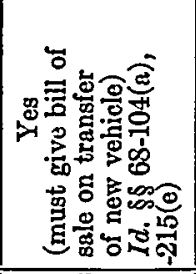 & 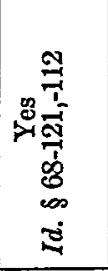 & 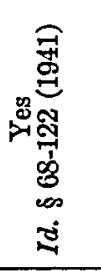 & 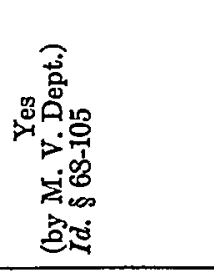 & 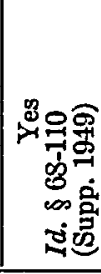 & 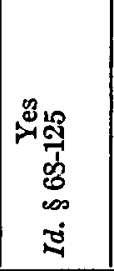 & \\
\hline 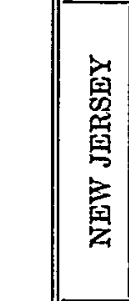 & 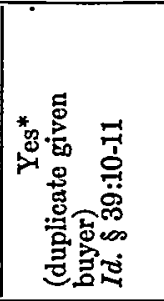 & 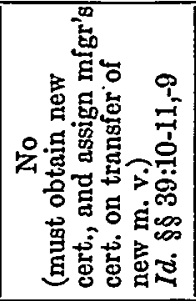 & 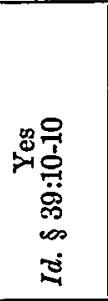 & 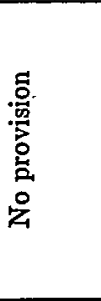 & 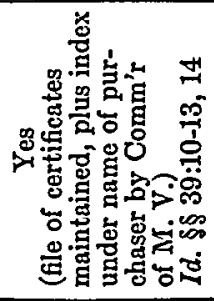 & 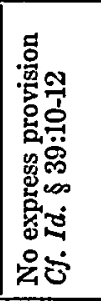 & 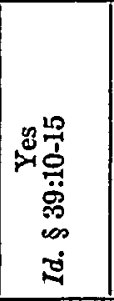 & 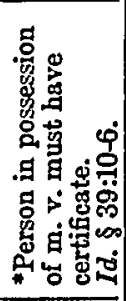 \\
\hline & 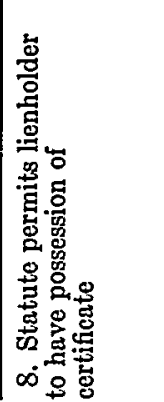 & 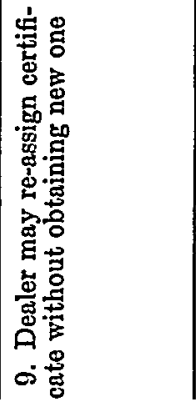 & 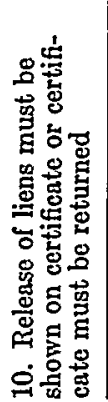 & 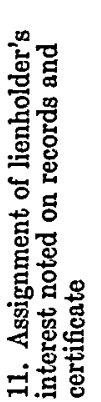 & 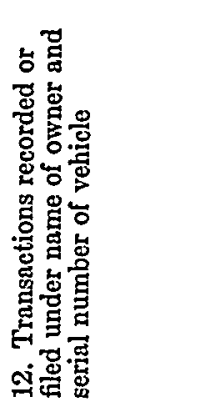 & 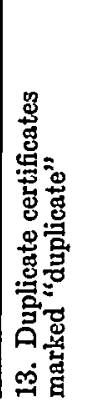 & 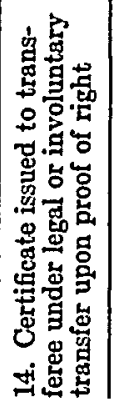 & \\
\hline
\end{tabular}


The Case of the Mystertous Accessory

\begin{tabular}{|c|c|c|c|c|c|c|c|}
\hline 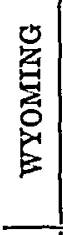 & 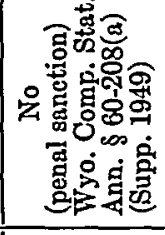 & 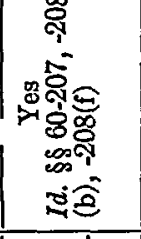 & 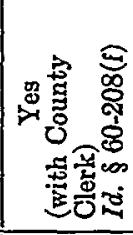 & 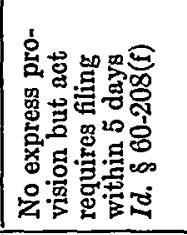 & 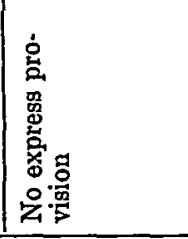 & 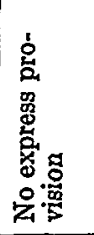 & 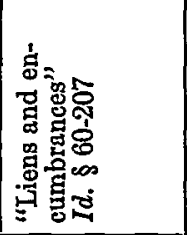 \\
\hline 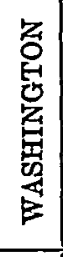 & 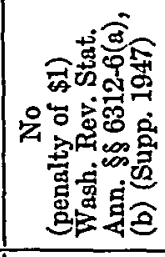 & 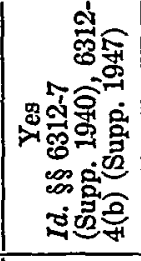 & 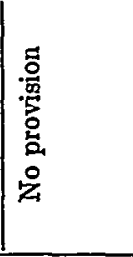 & 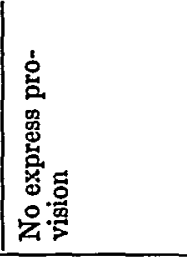 & 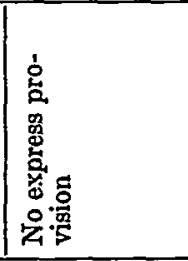 & 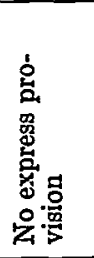 & 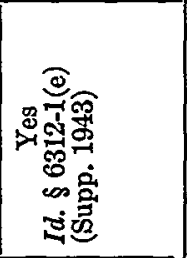 \\
\hline 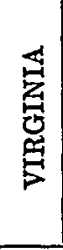 & 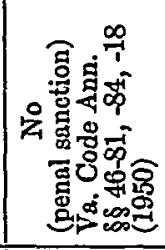 & 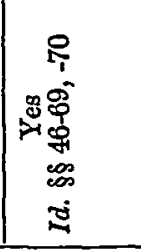 & 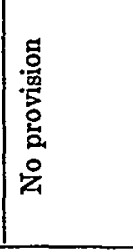 & 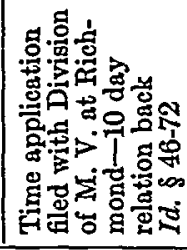 & 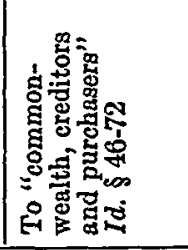 & 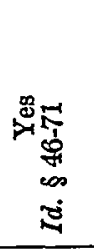 & 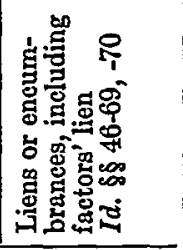 \\
\hline 思 & 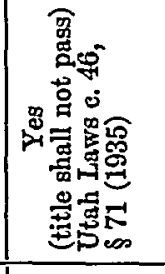 & 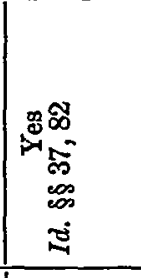 & 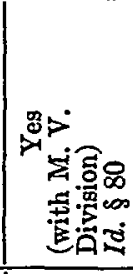 & 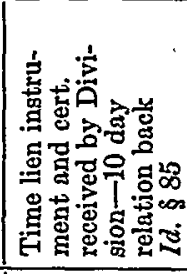 & 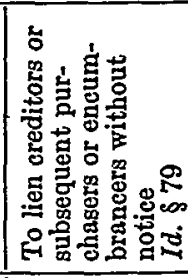 & 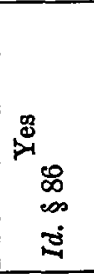 & 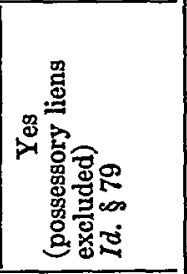 \\
\hline $\begin{array}{l}\text { 号 } \\
\text { 舄 }\end{array}$ & 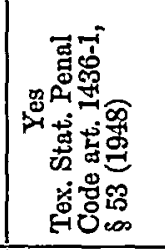 & 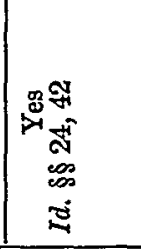 & 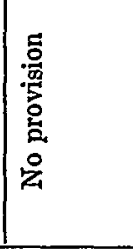 & 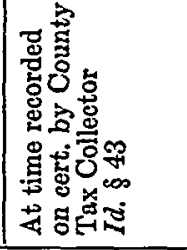 & 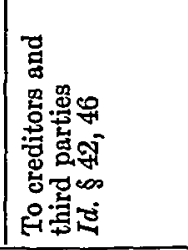 & 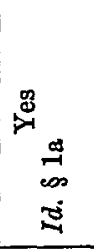 & 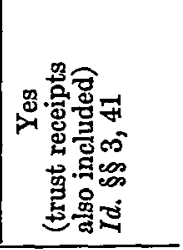 \\
\hline 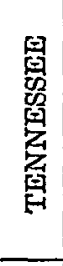 & 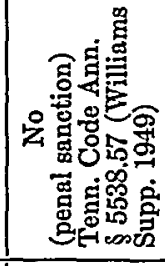 & 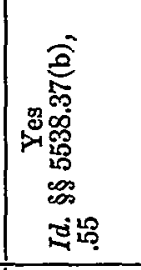 & 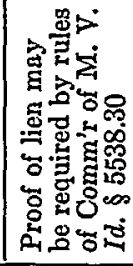 & 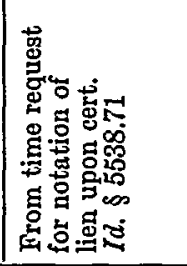 & 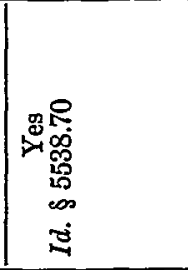 & 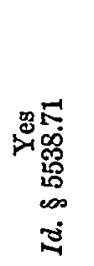 & 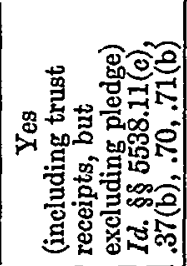 \\
\hline & 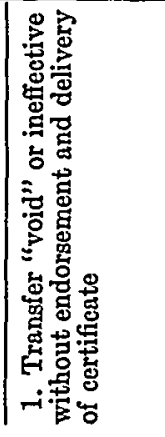 & 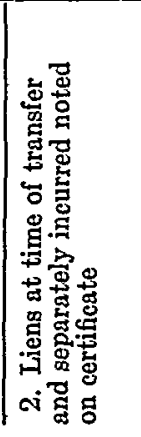 & 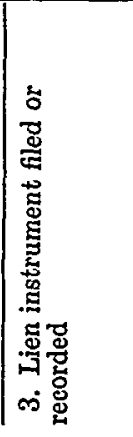 & 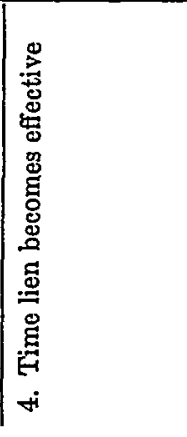 & 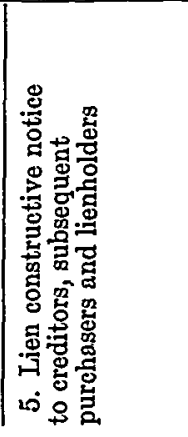 & 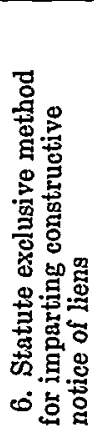 & 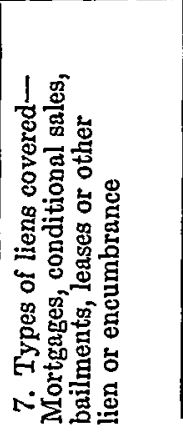 \\
\hline
\end{tabular}




\begin{tabular}{|c|c|c|c|c|c|c|c|}
\hline \multicolumn{2}{|l|}{$24^{8}$} & \multicolumn{5}{|c|}{ LAW AND CoNTEMPORARY ProBLEMS } & \multirow[b]{2}{*}{ 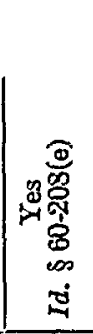 } \\
\hline 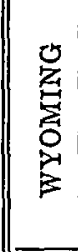 & 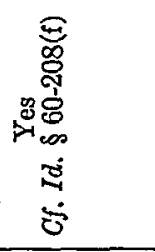 & 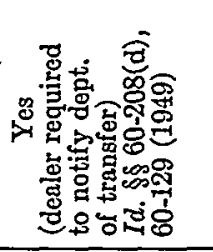 & 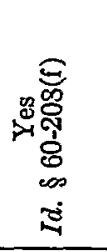 & 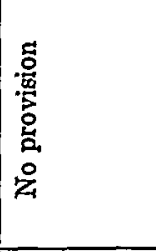 & 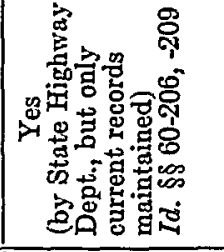 & 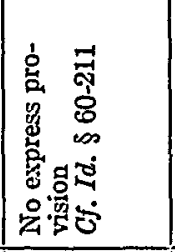 & \\
\hline 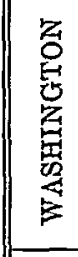 & 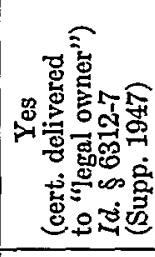 & 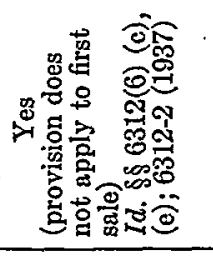 & 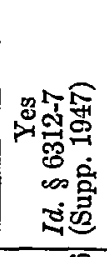 & 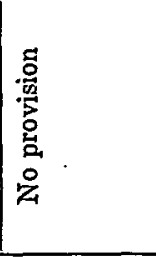 & 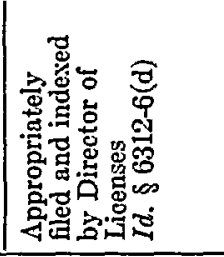 & 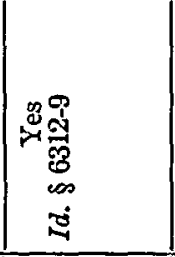 & 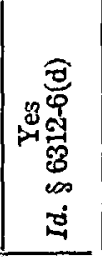 \\
\hline 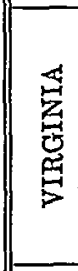 & 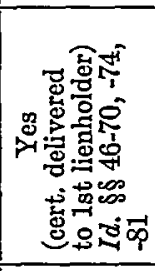 & 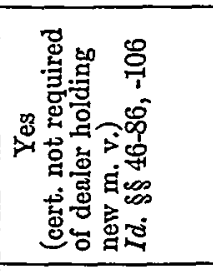 & 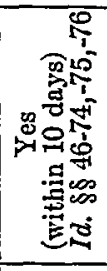 & 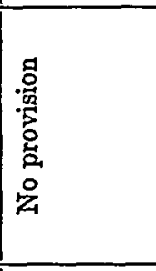 & 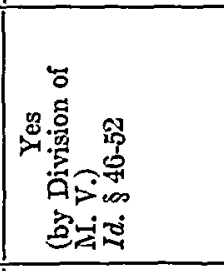 & 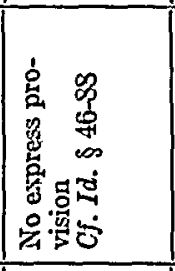 & 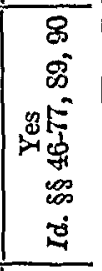 \\
\hline 焉 & 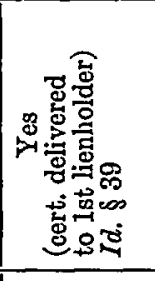 & 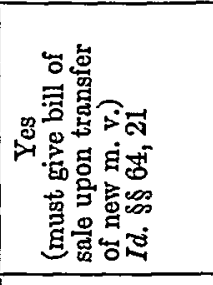 & 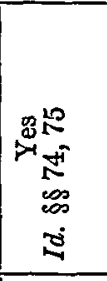 & 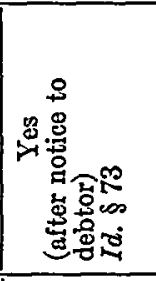 & 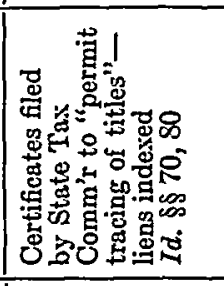 & 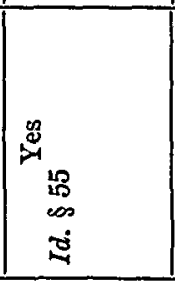 & 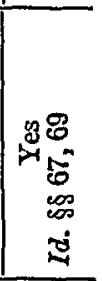 \\
\hline 瓷鼻 & 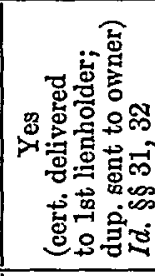 & 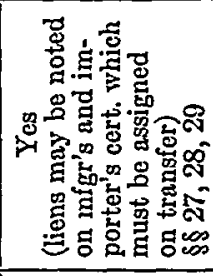 & 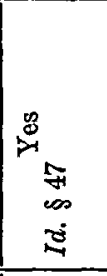 & 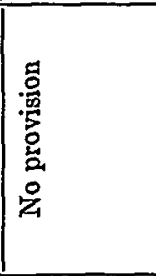 & 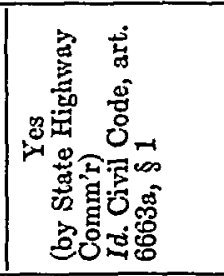 & 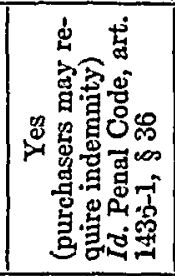 & 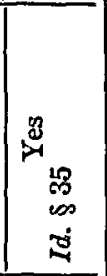 \\
\hline 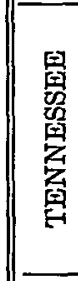 & 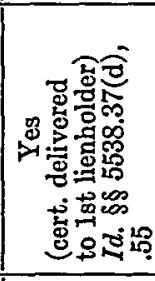 & 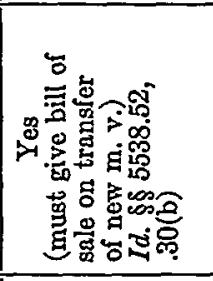 & 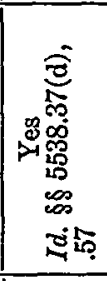 & 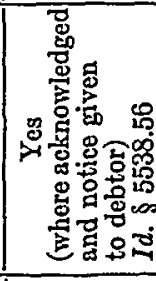 & 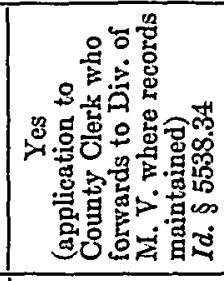 & 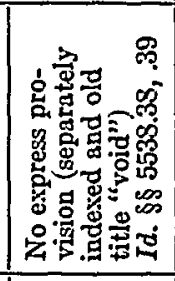 & 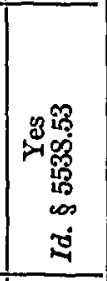 \\
\hline & 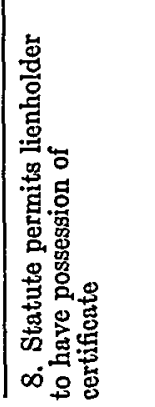 & 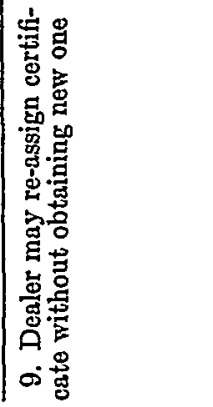 & 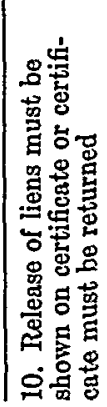 & 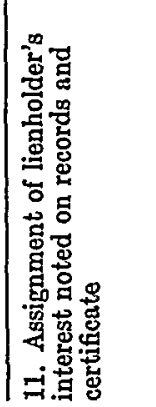 & 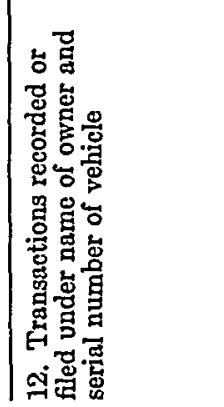 & 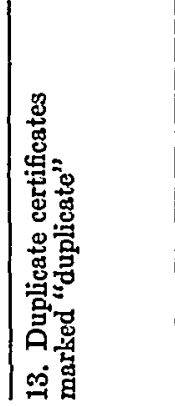 & 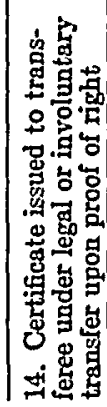 \\
\hline
\end{tabular}

